\title{
LA ONOMÁSTICA DE LA CONVERSIÓN: SEÑAS DE IDENTIDAD Y TRANSFORMACIÓN ANTROPONÍMICA DE LOS MORISCOS DE GRANADA (1500-1569)*
}

\author{
Gonzalo Carrasco García**
}

\begin{abstract}
Además de otros hechos deshonrosos y numerosos actos viles, Cambiaron nuestros nombres sustituyéndolos sin nuestro consentimiento ni nuestro deseo.

¡Ay del cambio de la religión de Mūhāmmmād por la religión de los perros cristianos, las peores criaturas!

¡Ay de nuestros nombres cuando fueron remplazados por los nombres de esos burros ignorantes! ${ }^{1}$
\end{abstract}

Los versos de la petición de auxilio al emperador otomano Bāyazīd II expresan la rabia y la consternación que sentían los musulmanes de Granada ante la quiebra de las capitulaciones de Granada. Los bautizos forzosos que tuvieron lugar a partir de diciembre de 1499 no sólo pretendieron desenraizar -al menos nominalmente- la fe islámica de la población autóctona de Granada, sino que los demás rasgos culturales de esta comunidad también se verían progresivamen-

* Este trabajo ha sido posible gracias a la financiación concedida en el marco del XIX Concurso de Ayudas a la Investigación para Temas Mudéjares 2007 del Centro de Estudios Mudéjares de Teruel. El estudio de las nóminas de bautizos de Granada tiene su origen en el proyecto del profesor Miguel Ángel Ladero Quesada (BHA 2002-03292, Hacienda real, poder político y sociedad en Castilla. 1406-1474-1516), a quien quisiera agradecer por haberme animado a participar y dirigido en la investigación original, y también a los profesores Cristina Álvarez Millán, Ana Echevarría Arsuaga y Luis Bernabé Pons por su generosa ayuda y sus valiosas sugerencias, aunque quedo yo sólo responsable de todo descuido u omisión.

** Doctorando en la Universidad Complutense de Madrid. B.A. Historia, Université de Montréal (Canadá); M.A. Teoría política, Simon Fraser University (Canadá).

1. Extracto (versos 54 a 57) de una qașīda árabe anónima escrita posiblemente en 1501 como una petición urgente de ayuda por parte de los moriscos a Bāyazìd II. Se encuentra en el Azhār ar-Riyāọ de al-Maqqarī. La trascripción completa del texto árabe, su traducción inglesa y su estudio se encuentran en J.T. MONROE, «A Curious Appeal to the Ottoman Empire», AlAndalus, 31:1/2, 1966, pp. 281-303; los versos árabes aquí citados en p. 291. 
te cercenados por medidas coercitivas cuyo éxito es cuestionable. Si bien los amplios estudios sobre moriscos han logrado dilucidar las claves sobre la evolución -decadencia o aferramiento cultural- de dicha comunidad, existe al menos un elemento intrínseco a la cultura islámica que merece mayor atención, en concreto, el nombre de los granadinos musulmanes antes y después de la conversión.

Gracias, en primer lugar, a una fuente privilegiada y poco común como son las nóminas de los bautizos masivos de 1499-1500, podemos identificar tanto los apelativos árabes como el nuevo nombre castellano otorgado al neófito. Este documento ha sido de gran utilidad en otros estudios para extraer patrones sociológicos de la sociedad musulmana del antiguo emirato nazarí, amén de esclarecer detalles sobre el proceso de conversión forzosa que acabaría arrastrando a toda Granada ${ }^{2}$.

Nuestro propósito inicial es establecer el retrato onomástico de una muestra representativa de la población granadina al filo de la conversión en el cambio del siglo XV al XVI. No obstante, no se puede lograr un retrato relativamente fiel sin una consideración tanto del objeto principal de estudio -la onomástica como tal- como de los problemas metodológicos surgidos de las fuentes de donde se extraen las muestras antroponímicas. Debido a que nuestro objeto abarca dos formas de nombrar asociadas a dos ámbitos étnico-religiosos y a dos idiomas vernáculos, es preciso identificar la convivencia antroponímica en un mismo individuo que cruza, adapta y fusiona rasgos de ambos sistemas onomásticos por una parte, y calibrar, por otra, la pervivencia de elementos del sistema antroponímico árabe de la comunidad morisca como indicador cultural que se resiste a la asimilación. En otras palabras, es esencial constatar la existencia de un cierto sincretismo onomástico además de medir hasta qué grado se ha podido conservar el uso antroponímico tradicional como reflejo de la supervivencia cultural del elemento árabe-islámico.

Una vez examinadas todas las dudas sobre la metodología, la conceptualización y el alcance de la onomástica, se desglosarán los distintos repertorios de nombres y sobrenombres ${ }^{3}$ árabes dentro de su propia estructura, seguido de los

2. Fue el profesor Ladero Quesada quien primero identificó y analizó estas nóminas, y quien dirige el proyecto de su edición y estudio. Ver los siguientes estudios: M.A. LADERO QUESADA, «Nóminas de conversos granadinos (1499-1500)», en Granada después de la conquista: Repobladores y Mudéjares, Granada, Diputación Provincial de Granada, 1993, pp. 615-649; M.A. LADERO QUESADA, «Los bautismos de los musulmanes Granadinos en 1500», Actas del IX Simposio Internacional de Mudejarismo, Teruel, Centro de Estudios Mudéjares, 2004, pp. 481-542; y G. CARRASCO GARCÍA, «Huellas de la sociedad musulmana granadina: la conversión del Albayzín (1499-1500)», En la España Medieval, 2007, Vol. 30, pp. 335-380.

3. En este estudio utilizamos la palabra "sobrenombre" en su sentido más amplio de apelativo complementario que va unido al nombre de pila cristiano, o en el sistema onomástico árabe al ism. No se parte del presupuesto de que el sobrenombre ejerza específicamente de apellido en sentido moderno, de patronímico, mote, indicador de linaje, ni de ninguno de los distintos elementos que integran la cadena onomástica árabe. Es decir, puede ser cualquiera de estos componentes, pero (con contadas excepciones) damos por hecho que no es ni un segundo nombre personal ni un ism 'alam. 
nombres y sobrenombres castellanos según su lógica intrínseca. Se planteará el problema de la relación del cambio antroponímico para avanzar ciertas hipótesis sobre cómo se han determinado los nombres de los neófitos. Asimismo, se revisarán las normas que afectaron al uso de un nombre u otro en la etapa morisca, para entender tanto el contexto antropológico como el legal al que estuvo expuesto y que intervino en mayor o menor grado en su transformación.

El último objetivo del estudio será situar estas nóminas en un contexto comparativo sincrónico y diacrónico. Se contrastará una muestra del elenco antroponímico de $1500^{4}$ con una serie de repertorios onomásticos tanto del ámbito árabe-islámico (andalusí y mudéjar) como del cristiano y morisco en el tiempo y en el contexto esencialmente castellano con respecto a los antropónimos cristianos. Con el uso de otras nóminas moriscas y viejo-cristianas de la misma ciudad de Granada de la década de los sesenta del siglo XVI se procederá a una comparación diacrónica para efectuar un seguimiento de los conversos de 1500 y poder ponderar tendencias de aculturación formal y no-formal. Sin esos referentes espacio-temporales no se puede comenzar a discernir patrones evolutivos en la antroponimia musulmana-mudéjar-morisca en el contexto hispano donde dos sistemas onomásticos compartieron -a menudo de forma incómoda y contradictoria- un mismo espacio.

\section{LA METODOLOGÍA DE LA ONOMÁSTICA: ÁMBITOS, ENFOQUES, PROPÓSITOS}

A pesar de los numerosos estudios realizados sobre antroponimia desde hace más de un siglo ${ }^{5}$, muchos especialistas consideran que este método histórico está aún en su infancia y alberga todavía un gran potencial ${ }^{6}$. Si limitamos

4. Archivo Histórico Nacional (AHN), Universidades, legajos 720, folios 168-189 (paginación antigua), o pp. 275-317 (paginación moderna).

5. Un estudio decimonónico que aún resulta útil para el ámbito hispánico es el de J. Godoy ALCÁNTARA, Ensayo histórico, etimológico, filológico sobre los apellidos castellanos, Madrid, 1871. Aunque ya con más de medio siglo a sus espaldas, otro clásico algo más reciente es el de G. DíEZ Melcón, Apellidos castellano-leoneses (siglos IX-XIII ambos inclusive), Granada, Universidad de Granada, 1957. En cuanto a la onomástica árabe contamos con el estudio de J. GARCIN DE TASSY, «Mémoire sur les noms propres et sur les titres musulmans», Journal Asiatique, série 5, III, 1854, pp. 422-510; asimismo, sigue siendo referencia obligatoria casi un siglo después el proyecto de corpus onomástico de L. CAETANI y G. GABRIELI, Onomasticon Arabicum, ossia repertoria alfabetica dei nomi di persona, Vols. I y II, Roma, Casa Editrice Italiana, 1915.

6. Esta es la visión que mantienen algunos de los principales difusores del análisis antroponímico en la Europa medieval, como es el caso de M. Bourin y B. CHEvalier, «L'enquête: Buts et méthodes», en M. Bourin (ed.), Genèse médiéval de l'anthroponymie moderne, Tours, Université de Tours, 1990, pp. 7-12. En cuanto al estudio onomástico árabe para la Edad Media encontramos el mismo parecer en P. GUICHARD, «L'anthroponymie des zones de contact entre monde chrétien et monde musulman: de Palerme à Tolède», en M. Bourin, J.-M. MARTin y F. MENANT (eds.), L'anthroponymie, document de l'histoire sociale des mondes méditerranéens médiévaux. Actes du Colloque international (Rome, 6-8 octobre, 1994), Roma, Collection de l'École Française de Rome (226), 1996, pp. 112-113. 
la mirada al contexto de la Península Ibérica en la Edad Media, se constatan dos tipos de estudios antroponímicos que se llevan a cabo de forma paralela sin que haya demasiado contacto entre ambos: la investigación de la onomástica árabe por un lado $^{7}$ y la onomástica cristiano-latino-romance por otro ${ }^{8}$.

Se podría decir que existe hasta una cierta segregación de disciplinas que dificulta ese intercambio. Esto tiene que ver en parte con el hecho de que la historiografía tradicional ha separado el estudio de los reinos cristianos hispánicos del estudio de al-Andalus. No obstante, la división académica se debe parcialmente a la diferenciación lingüística de los dos objetos de estudio. Decimos parcialmente porque, mientras que existe un número considerable de análisis de conjunto, simposios, y obras monográficas que incorporan varios ámbitos lingüísticos europeos en los estudios onomásticos ${ }^{9}$, realmente son pocas las obras de este tipo que incluyen algún ejemplo del ámbito árabe (occidental u oriental). La razón no radica exclusivamente en el hecho idiomático -aunque se derive de él- sino fundamentalmente en la originalidad y complejidad del sistema onomástico árabe con respecto a las estructuras que imperan en los espacios lingüísticos europeos.

Asimismo, el énfasis de los arabistas sobre los estudios onomásticos viene dado en parte por la tradición que nace en los albores de la historia islámica con la ciencia de la genealogía y que cobra importancia por la necesidad de probar el vínculo de sangre de ciertos personajes de la nobleza y la política con el profeta Mahoma. Por otra parte, también surge de la obligación que tienen los musulmanes de conservar en la memoria los hechos que tuvieron lugar en los primeros momentos del Islam y de transmitir estas tradiciones primigenias intactas. De ahí que desarrollaran un proceso elaborado de transmisión de información a través de citas de autoridades y sus transmisores cuya fiabilidad se hace perentoria con el objetivo de evitar la distorsión de los hechos. Los transmisores son eslabones fundamentales dentro de la vida intelectual de la civilización árabe. Por ende, su nombre es cuidadosamente conservado de forma abreviada en las cadenas onomásticas y su identidad recuperable a través de los

7. Una buena bibliografía y estado de la cuestión de la onomástica islámica puede verse en M. MARín, «Estudios sobre antroponimia árabe: bibliografía y balance», en M.L. ÁvILA (ed.), Estudios onomástico-biográficos de al-Andalus, II, Granada, CSIC, 1989, pp. 137-164; una buena introducción al tema es la obra de A. ScHIMMEL, Islamic Names, Edimburgo, Edinburgh University Press, 1989.

8. Para una breve introducción a los estudios onomásticos medievales en la Península Ibérica ver P. MARTínez SOPENA, «Notas sobre la antroponimia hispánica medieval», Medievalismo. Boletín de la Sociedad Española de Estudios Medievales, 4, 1994, pp. 189-197. Para una bibliografía más completa que abarca un periodo más amplio ver M. ARIZA, Intento de bibliografía de la Onomástica Hispánica, Cáceres, Universidad de Cáceres, 1981.

9. El ejemplo más reciente es la obra coordinada por M. Bourin y P. MARTínez SOPENA (eds.), Anthroponymie et déplacements. Migrations, réseaux, métissage dans la chrétienté médiévale. Coloquio celebrado en la Casa de Velázquez, Madrid, 28-29 de mayo de 2007 (en prensa). 
diccionarios bio-bibliográficos que contienen el nombre en su formulación más extensa repleto de indicios sobre la vida de dichos sabios ${ }^{10}$. Esa riqueza documental hace que muchos arabistas se dediquen directa o indirectamente al estudio onomástico, especialmente allí donde escasean otras fuentes primarias (i.e.: la historiografía de al-Andalus) ${ }^{11}$.

Antes de desglosar los dos sistemas que surgieron en la Península Ibérica, es necesario comprender por qué esta división dificulta un análisis que incluye un cruce de ambas estructuras antroponímicas como se pretende exponer en este estudio. El análisis onomástico se puede enfocar de dos formas distintas. En primer lugar, el propósito del estudio es trazar la evolución antropológica sobre cómo y de qué manera se otorga, adquiere o utiliza un nombre -el aspecto descriptivo-. Aquí, tanto el sujeto como el objeto de la investigación es el nombre.

Para la mayoría de los historiadores, sin embargo, el estudio onomástico es útil en la medida en que puede aportar indicios sobre incógnitas que difícilmente podrían resolverse a través de otras fuentes: se estudia el nombre para averiguar otra cosa -el aspecto analítico-. El nombre alberga una información valiosa en su interior que puede ser extraída para identificar otras cuestiones que no tienen que ver necesariamente con la forma de nombrar a un individuo dentro de un colectivo. Estas cuestiones suelen estar relacionadas con la sociología, la economía, la demografía o la geografía además de la genealogía. Un nombre puede esconder el rastro migratorio de un individuo, su estatus social, su profesión laboral, su origen étnico, su credo y muchas otras cosas. No obstante, la precaución metodológica es imprescindible debido a que también puede encubrir pistas equívocas que deben ser sorteadas para evitar extraer conclusiones falsas.

Aquí, nuestro propósito es en realidad un híbrido entre estos dos planteamientos del análisis onomástico. Por una parte, nos interesan las formas del apelativo (el cómo y de qué manera). Sin embargo, no nos interesa por el hecho en sí, sino en la medida en que el nombre se transforma en un marcador o indicador cultural. No se debe pensar en el nombre como un elemento de diferencia meramente accidental o irrelevante. En el estudio onomástico comparativo se pueden identificar alteraciones colectivas del nombre que nos están indicando sutilmente unas transformaciones culturales (el porqué), debido -en nuestro caso concreto- a la presencia desigual de dos culturas, una de las cuales presiona de forma predominante sobre la otra sin llegar a imponerse por completo.

10. Para una sucinta introducción al desarrollo de la onomástica en la historia del Islam ver J. Sublet, «Nom et identité dans le monde musulman», en M. Bourin, J.-M. MARTIN y F. MENANT (eds.), op. cit., especialmente pp. 98-101.

11. Un claro reflejo es la importante serie que viene publicando el CSIC desde hace varias décadas, Estudios onomástico-biográficos de al-Andalus, aunque no todas las contribuciones son estudios propiamente sobre onomástica. 


\section{ANTECEDENTES HISTORIOGRÁFICOS}

Este es el caso de las comunidades musulmanas que pasan de un estado de libertad religiosa y cultural en un contexto político islámico a uno de forzosa apostasía, renunciando a características antropológicas fundamentales, habiendo pasado previamente por un estado de vasallaje a un rey cristiano con la presión social que implica la cultura cristiana, pero sin renunciar a la libertad de confesión. El análisis antroponímico de los musulmanes-mudéjaresmoriscos requiere inevitablemente hacer uso de ambos métodos analíticos de los estudios onomásticos. Si los foros donde se transmiten las ideas tienden a obviar los estudios del otro ámbito, aún más difícil es encontrar estudios que incorporen el análisis de ambos sistemas antroponímicos. La división disciplinaria entre arabismo e hispanismo -al igual que la separación algo artificiosa entre estudios mudéjares y estudios moriscos con frecuencia separados por la barrera historiográfica temporal entre historia medieval e historia moderna- ${ }^{12}$ ha creado una cierta carencia de investigadores que hayan dedicado sus pesquisas a este tema.

Uno de los pioneros que logró superar estas limitaciones historiográficas y que ha indagado sobre el tema concreto de la onomástica morisca es Martínez Ruiz. A partir de censos de bienes habices de Granada y otras fuentes del siglo XVI ha logrado crear repertorios en varias ocasiones de los vestigios onomásticos árabes de la comunidad conversa de moro ${ }^{13}$. Otro importante estudio que organiza el vasto acervo antroponímico morisco, en este caso para el ámbito levantino y basado en fuentes inquisitoriales, es la investigación de Labarta $^{14}$. Algunos estudios de Labarta, así como de otros arabistas, han sabido aprovechar estas fuentes romances para analizar también la fonética y el dialecto árabe regional, un recurso adicional que nos brinda la onomástica transcultural, pero que evidentemente excede nuestro propósito en este trabajo ${ }^{15}$.

12. Epalza ve necesario cambiar la concepción histórica tradicional de la sociedad musulmana en la Península Ibérica a través de sus múltiples encarnaciones. En el fondo no deja de ser el mismo colectivo sujeto a una evolución debido a una serie de avatares múltiples: ver M. de EPALZA, «Les morisques vus à partir des communautés mudéjares précédentes», en Les morisques et leur temps, Paris, 1983, pp. 29-41.

13. Ver principalmente J. MARTÍNEZ RUIZ, «Antroponimia morisca granadina en el siglo XVI y su interés para la onomástica hispánica», XI Congreso internacional de lingüística y filología románicas, IV, Madrid, 1968, pp. 1935-1957. Otros estudios suyos serán citados más adelante. También encontramos el estudio realizado para Guadix de C. AsEnJo SEDANO, Toponimia y antroponimia de Wādī āš, s. XV, Granada, Diputación de Granada, 1983, o el estudio sobre el Cenete con fuentes árabes del siglo XVI de J. Albarracín Navarro, M. Espinar Moreno, J. Martínez Ruiz y R. RuIz PÉrez, El marquesado del Cenete: Historia, Toponimia y onomástica según documentos árabes inéditos, Granada, Universidad de Granada, 1986.

14. A. Labarta, La onomástica de los moriscos valencianos, Madrid, CSIC, 1987.

15. Sobre este tema, ver A. LABARTA, «La antroponimia árabe en grafía latina como fuente lingüística», en M.L. Ávila (ed.), op. cit., pp. 165-175. 
En lo que concierne a la onomástica árabe de la comunidad mudéjar contamos con menos estudios, en parte por la evidente penuria de fuentes ${ }^{16}$. No obstante, gracias a la ardua tarea de acopiar el rastro furtivo de los mudéjares de Toledo, Molénat fue uno de los primeros en crear repertorios para el caso castellano, en establecer patrones y presentar algunas teorías muy sugerentes que tendremos en cuenta a la hora de proponer cualquier pauta con respecto a nuestra muestra en un marco comparativo ${ }^{17}$.

El estudio más solvente sobre antroponimia mudéjar que tiene en cuenta el camino abierto por Molénat es el de Laliena Corbera sobre los mudéjares de Aragón ${ }^{18}$. Esta investigación tiene como objetivo explícito estudiar la antroponimia árabe para calibrar el grado de aculturación de la comunidad mudéjar, fenómeno de difícil medición que a menudo ha sido ignorado por esta misma razón. La novedad reside en que se utilizan documentos árabes para extraer una escueta muestra y compararla estadísticamente con otra muestra derivada de documentos cristianos, acabando con unas reflexiones sobre la antroponimia después de la conversión y rompiendo así la barrera historiográfica mudéjar-morisca $^{19}$.

16. Si ya de por sí las fuentes cristianas sobre mudéjares -especialmente en el caso castellanoson escasas (ver M.A. LADERO QuESADA, «Los mudéjares en los reinos de la Corona de Castilla. Estado actual de su estudio", Actas del III Simposio Internacional de Mudejarismo, Teruel, 1986, pp. 5-20), son aún más pobres las fuentes árabes que han sobrevivido de los mudéjares y el caso más deficiente, de nuevo, es el castellano: ver M.J. VIGUERA, «Les mudéjars et leurs documents écrits en arabe», Revue du Monde Musulman et de la Méditerranée, 63-64, 1-2, 1992, pp. 155-164.

17. Además de los títulos citados más abajo, ver por ejemplo, J.-P. MolÉNAT, «Les musulmans de Tolède aux XIVe et XVe siècles», Les Espagnes mediévales: aspects économiques et sociaux. Mélanges offerts à Jean Gautier Dalché, Paris-Nice, Les Belles Letres, 1983, pp. 175-190; J.-P. MoléNAT, «Mudéjars et mozarabes à Tolède du XIIe au XVe siècle», Revue du Monde Musulman et de la Méditerranée, 63-64, 1-2, 1992, pp. 143-153. Este investigador, además de analizar a los mudéjares, también considera la etapa posterior a la conversión, por ejemplo en J.-P. MOLÉNAT, «À propos des noms et des mosquées des vieux mudéjars de Castille après l'édit de février 1502», Actas del IX Simposio Internacional de Mudejarismo, Teruel, Centro de Estudios Mudéjares, 2004, pp. 543-554. De otros autores ver también, M. GARCíA-ARENAL, «Dos documentos sobre los moros de Uclés en 1501», Al-Andalus, 42, 1977, pp. 167-181; F. MATEO LlOPIS, «Nómina de los musulmanes de las montañas de Coll de Rates del Reino de Valencia, en 1409», Al-Andalus, 7, 1942, pp. 299-335; K. WAGNER, «Un padrón desconocido de los mudéjares de Sevilla y la expulsión de 1502», Al Andalus, XXXVI, 1971, pp. 373-382; y más recientemente, M.F. LOPES DE BARROS, "Antroponímia muçulmana», en Tempos e espaços de mouros. A minoria muçulmana no Reino Português (séculos XII a XV), Lisboa, Fundação Gulbenkian, 2007, pp. 258-299.

18. C. LALIENA CORBERA, «La antroponimia de los mudéjares: resistencia y aculturación de una minoría étnico-religiosa», en M. Bourin, J.-M. MArTin y F. MENANT (eds.), op. cit., pp. 143-166.

19. No podemos dejar de mencionar otro estudio relevante que, a pesar de no recurrir al análisis cuantitativo, aboga por la utilización de la onomástica para dilucidar el proceso de aculturación de la población musulmana granadina antes y después de la conversión: A. ARECES GUTIÉRREZ, «Aproximación a la antroponimia mudéjar-morisca de Andalucía oriental reflejada a través de documentos romances relativos a la repoblación», Actas del VII Simposio Internacional de Mudejarismo, Teruel, Centro de Estudios Mudéjares, 1999, pp. 663-678. 


\section{EL DOBLE SISTEMA ONOMÁSTICO Y EL SINCRETISMO ANTROPONÍMICO}

Son minoritarios los estudios relacionados con colectivos que se encuentran en la frontera de dos concepciones culturales y por consiguiente dos estructuras antroponímicas. A menudo surge una dificultad conceptual por querer equiparar ambas configuraciones onomásticas. Por una parte está la visión de Guichard, que aduce que existe una incompatibilidad casi absoluta entre las dos estructuras, donde la impermeabilidad radica en el choque de la riqueza expresiva de la antroponimia árabe contra la poco reveladora antroponimia europea $^{20}$. Por su parte, Molénat, aun reconociendo la dificultad de cruzar fronteras antroponímicas, aboga por considerarlos dos sistemas onomásticos independientes vinculados intrínsecamente al idioma en que se ven expresados (árabe por una parte y romance por otra). De ahí que ambos sistemas puedan coexistir en un contexto de bilingüismo, sin que haya interferencias ostensibles $^{21}$. Por consiguiente, el doble sistema onomástico dio lugar a que un individuo tuviera dos apelativos diferentes y recíprocamente reconocidos según el idioma en que se configuraba o expresaba. Esta dualidad onomástica se constata, como veremos más adelante, a partir del establecimiento de una comunidad mozárabe en tierras cristianas del norte de la Península Ibérica donde se puede comprobar la dualidad del nombre según el idioma en el que se formulaba. Aquí la onomástica no está forzosamente vinculada a la religión (como se podría creer en un origen) sino al idioma y a la expresión cultural. No obstante, Molénat, al contrario que Guichard, sí cree que puede haber un cruce, o adaptación de una estructura con aspectos de la otra, es decir, un acoplamiento de componentes del sistema onomástico árabe al sistema onomástico romance como ocurriría con la población mudéjar en la Baja Edad Media ${ }^{22}$. El paso del sistema árabe al sistema romance implica una simplificación (aspecto positivo), pero también un empobrecimiento (aspecto negativo). Asimismo, el propio sistema cristiano-romance en el siglo XIV y XV no es fijo: en un mismo documento, el nombre puede figurar de diversas formas ${ }^{23}$.

A nuestro parecer, la teoría de Molénat debería ser matizada. Por una parte esa falta de fijación del sistema onomástico cristiano tiene su contrapartida en la flexibilidad del sistema onomástico árabe. Las diversas partes del sistema árabe pueden aumentarse o reducirse, como veremos, según las necesidades, según el tipo de documento. Al igual que un individuo cristiano puede llamarse de múltiples formas, el individuo árabe también. Asimismo, queremos hacer especial hincapié en otra cuestión que rara vez tiene en cuen-

20. P. GUICHARD, op. cit., pp. 111 y 116-117.

21. J.-P. MoLÉNAT, «L'onomastique tolédane entre le XIIe et le XVe siècle. Du système onomastique arabe à la pratique espagnole moderne», en M. BOURIN, J.-M. MARTIN y F. MENANT, op. cit., p. 168.

22. Ibídem, p. 170.

23. Ibídem, p. 176. 
ta la historiografía de la onomástica árabe: la mayor parte de las investigaciones se basan en fuentes que documentan una clase social privilegiada o de sabios censados en los diccionarios bio-bibliográficos ricos en individuos con dilatadas cadenas onomásticas.

Es preciso, como alerta Guichard, detenerse un instante y preguntarse "¿cuál es el verdadero nombre de un individuo?" 24 . Es esencial introducir el concepto del nombre teórico o virtual que se utiliza en un amplio número de estas investigaciones y contrastarlo con un nombre más práctico, aun siendo un nombre que probablemente se aleje del nombre usual, utilizado por el individuo ${ }^{25}$. El nombre es susceptible de ser recogido de distintas formas dentro del mismo sistema, pero con mayor o menor complejidad. Sublet habla del nombre teórico como un nombre esencialmente póstumo que nunca fue utilizado por el propio individuo y, sin embargo, éste es el nombre sobre el cual se trabaja esencialmente ${ }^{26}$.

Nuestro estudio se aleja de la elite cultural, social y política que figura en los diccionarios bio-bibliográficos para hacer un retrato más fiel de la sociedad nazarí al borde de una inflexión existencial. Aquí recogemos expresiones onomásticas de personas comunes sin excluir ningún estamento de la sociedad, en la que se incluye también una cierta elite administrativa y religiosa que optó por permanecer en Granada al menos en un primer momento. Se trata de una muestra más representativa, aunque mediatizada por escribanos que desconocían el idioma árabe y que transliteraron su nombre en caracteres latinos para un objetivo ritual sin carácter propiamente administrativo. La fuente está ostensiblemente viciada pero, como veremos a lo largo del estudio, quizás no tan distorsionada como se ha pensado en la representación del apelativo árabe original que estaba a punto de desaparecer oficial aunque no oficiosamente.

\section{SOBRE EL CONCEPTO ANTROPOLÓGICO DE LA ACULTURACIÓN}

La transformación cultural de los moriscos es un proceso en el que los factores externos que vienen impuestos inicialmente de manera normativa por ciertas autoridades se ven parcial o totalmente filtrados, aceptados, rechazados o sintetizados por la comunidad subordinada. Estamos ante un fenómeno de aculturación formal según la teoría antropológica de la cultura elaborada por Kroeber y adaptada por Glick y Pi-Sunyer para explicar el desarrollo cultural de la Península Ibérica en la Edad Media y Moderna ${ }^{27}$.

24. P. GUICHARD, op. cit., p. 110.

25. Ibidem, p. 122.

26. I. SUBLET, op. cit., pp. 102-103.

27. T.F. GLICK y O. PI-SUNYER, «Acculturation as an Explanatory Concept in Spanish History», Comparative Studies in Society and History, Cambridge, 11, 1969, pp. 136-154, especialmente pp. 151-152. Sobre la teoría antropológica de la cultura ver A.L. KROEBER, The Nature of Culture, Chicago, University of Chicago Press, 1952, especialmente la sección primera. 
Es preciso dejar claro el tipo de proceso de transformación social a la que se ven expuestos los moriscos de Granada -la aculturación formal- cuya lógica difiere de la más común que Kroeber denomina aculturación no-formal. Mientras que los colectivos étnicos suelen padecer históricamente cambios culturales graduales y a veces inconscientes a través de agentes no-formales de transmisión cultural (como sucedió en gran medida con los mozárabes, mudéjares, judíos...), es decir, no instigados explícitamente por instituciones o individuos con poder, el caso de la aculturación de los moriscos viene afectada principalmente por normas impuestas desde las autoridades cristianas. Sin embargo, la receptividad de estos factores depende en gran medida de las barreras adoptadas por el colectivo morisco para mitigar ese proceso cuyo objetivo por parte del transmisor cultural es incitar un cambio abrupto para supuestamente provocar su asimilación al grupo dominante. Partiendo de la base de que la noción de asimilación repentina es un oxímoron ${ }^{28}$, la cuestión no es tanto identificar si el colectivo se funde con la sociedad hegemónica, como discernir hasta qué punto y en qué aspectos culturales el fenómeno de la aculturación tiene lugar impulsado esencialmente por la lógica extrínseca de coaptación.

En lo que respecta a la evolución antroponímica es imprescindible partir de la base de que se imbrica dentro de un proceso inicial más amplio de un cambio religioso inducido, seguido de una creciente presión mediante disposiciones legales para forzar la asimilación que a su vez afectarían a otros rasgos sociales, incluido el sobrenombre árabe. No obstante, los cambios, aunque forzosos, ni implican a priori su adopción incondicional, ni se puede descartar que otros fenómenos no-formales intervengan ostensiblemente en su recepción.

\section{EL USO DEL NOMBRE ÁRABE EN DOCUMENTOS MUDÉJARES, NAZARÍES Y MOZÁRABES}

Antes de avanzar una hipótesis sobre la aculturación que experimentaron los nombres de los mudéjares y los musulmanes transcritos por escribanos latino-romances es imprescindible echar un vistazo a las escrituras de los mudéjares redactadas por ellos mismos en árabe, o en textos bilingües donde figura el mismo nombre en dos idiomas. Después, examinaremos brevemente las diferencias en la designación en textos nazaríes para desembocar en una reflexión sobre los nombres árabes en las fuentes cristianas.

28. Sobre la política cisneriana con respecto a la asimilación de la población islámica de Granada ver F. MÁrQuez VILLANUEVA, «El problema historiográfico de los moriscos», en El problema morisco desde otras laderas, Madrid, Libertarias, 1991, pp. 129-141. 


\section{LA CADENA ONOMÁSTICA ÁRABE}

La cadena onomástica árabe está dividida en una serie de componentes que pueden variar ligeramente de nomenclatura ${ }^{29}$. El nombre propio personal otorgado al recién nacido por los padres o abuelos se denomina ism 'alam. El elemento más original de la cadena onomástica que no tiene paralelo en el sistema antroponímico occidental es, sin embargo, la kunya, expresado con el prefijo $a b \bar{u}$ (padre) o umm (madre) seguido del nombre del hijo del individuo (en caso de que tuviera uno), o bien de una alusión metafórica (no es preciso haber tenido descendencia biológica para ostentar una kunya). El siguiente elemento intrínseco al sistema de designación árabe es el nasab o la cadena genealógica. Ésta se expresa a través de la partícula ibn (hijo de) o bint (hija de) seguido del nombre del padre, pudiendo alargarse con el nombre del abuelo, el bisabuelo, etc., siempre precedido por ibn. A continuación puede aparecer la nisba, o nombre de relación. Existen distintos tipos de nisba. La nisba geográfica ${ }^{30}$ hace referencia bien a un topónimo de origen, bien a distintos lugares visitados por el individuo dentro del espacio del dār al-islām. La nisba tribal indica pertenencia a un linaje o clan ancestral. Existen otros tipos de nisba menos frecuentes, como la que indica la adscripción a una corriente religiosa o escuela islámica. Por último encontramos el laqab o sobrenombre, que puede hacer referencia a un oficio, título honorífico o un simple mote por el que se conoce al individuo en cuestión. El orden puede variar pero, si nos encontramos con todos los elementos, normalmente aparece primero la kunya seguido del ism, el nasab, y la $n i s b a$, para acabar con el laqab ${ }^{31}$.

\section{EL ANTROPÓNIMO ÁRABE DE LOS MUDÉJARES EN DOCUMENTOS BILINGÜES}

En primer lugar, un conjunto muy revelador de documentos -del siglo XII en su mayoría y bilingües (árabe y latín) con variantes onomásticas- son los que publicó y estudió García-Arenal en relación a los mudéjares de Tudela y Ta-

29. Para una buena introducción al sistema onomástico árabe clásico ver M. MARín, Individuo y sociedad en al-Andalus, Madrid, Mapfre, 1992, pp. 175-182; o M.J. CERVERA FRAS, «El nombre propio árabe medieval. Sus elementos, forma y significado», en Aragón en la Edad Media, vol. IX, Zaragoza, Universidad de Zaragoza, 1991, pp. 225-240.

30. El antropotopónimo árabe a veces se denomina laqab de procedencia en vez de nisba geográfica; M.F. LOPES DE BARROS, «The Identification of Portuguese Muslims. Problems and Methodology», en M. MARín (ed.), Medieval Prosopography, número especial de Arabic-Islamic Medieval Culture, vol. 23, 2002, p. 222.

31. Debido a la trasformación que padecen las palabras árabes al pasar del singular al dual o al plural indefinido, para evitar confusión, todo término árabe utilizado en el texto y en concreto el uso de los términos onomásticos se mantendrán en su forma singular aunque en el texto el sustantivo sea plural (una kunya, varias kunya). 
razona $^{32}$. En lo que respecta a los nombres de mudéjares en la versión árabe del texto, más del 75\% de los apelativos contiene como mínimo el ism + el nasab genealógico (simple o doble); algo más de la mitad de todos los nombres árabes comprende al menos tres elementos y son escasos los que comportan cuatro. Por su parte, todos estos nombres transcritos en latín contienen sólo dos elementos $^{33}$, por lo que en más de la mitad de los casos existe una reducción antroponímica en el paso de un idioma a otro. No obstante, casi un tercio de los nombres árabes no contienen más que dos elementos por lo que coinciden con sus homónimos latinos. Laliena Corbera tiene razón al concluir que los nombres árabes transcritos en latín no son necesariamente ajenos al sistema antroponímico árabe y, más bien, se acoplan con formas más breves del propio sistema utilizado de diversas formas por los mudéjares ${ }^{34}$.

En segundo lugar, Molénat ya ha remarcado la importancia que tiene una traducción toledana de 1347 (de un texto árabe anterior) para entender la divergencia onomástica árabe-romance ${ }^{35}$. Encontramos de nuevo rubricada la firma bilingüe -en castellano y en árabe- de los testigos mudéjares toledanos que avalan la traducción y autenticidad del texto. Dos firmas interesan aquí: la de Muhammad ibn 'Alī al-Muhnnafī al-Šarafī, que se reduce al transcribirlo al castellano a Mahomad el Xaraffí; y la de su hijo Hamad ibn Muhammad ibn 'Alī al-Muhnafī al-Šarafī, que en castellano él escribe Hamete el Xarafí. Los cuatro elementos onomásticos del nombre árabe del padre, y cinco del hijo, se reducen a dos elementos, el ism y la nisba geográfica, al pasar al idioma de las autoridades castellanas. También, dos son los elementos que contienen los nombres de los otros tres testigos castellanos que le siguen, cuyas firmas se limitan a un nombre y un patronímico tanto en la versión latina como en la árabe.

En tercer lugar, en 1491 -en tiempo de los Reyes Católicos- se expidieron unos documentos en árabe para el nombramiento de unos alguaciles musulmanes en la sierra de Málaga. De nuevo, los alguaciles están citados con su

32. M. GARCÍA-ARENAL, «Documentos árabes de Tudela y Tarazona», Al-Qanțara, III, 1982, pp. 2772. El aspecto onomástico de estos documentos también ha sido tratado en C. LALIENA CoRBERA, op. cit., pp. 150-151.

33. Las únicas excepciones son las que nombran al individuo como hijo de su padre (Heiça, filius de Muza Alazeiri). Se puede defender el caso de que no estamos ante una referencia exclusivamente onomástica sino también de relación, donde el "filius de" no forma parte del nombre del individuo como tal. Sin embargo, debido a que en este momento la onomástica latina tampoco está fijada, se puede considerar parte del apelativo aunque éste se pueda transformar como en el caso árabe. Para estas cuestiones metodológicas sobre el nombre en la Plena Edad Media ver P. MARTínez SOPENA (coord.), Antroponimia y sociedad.

34. C. LALIEnA Corbera, op. cit., p. 151.

35. El texto fue publicado por F. FITA, «Marjadraque según el fuero de Toledo», Boletín de la Real Academia de la Historia, tomo VII, diciembre, 1885, pp. 371-376. El texto original se encuentra en el Archivo Histórico Nacional con la signatura antigua, Cajón toledano 2, Ciudad Real, I, 3, 1, 1. Ver el comentario onomástico en J.-P. MoléNAT, «Les musulmans de Tolède...», p. 187, y «L'onomastique tolédane...», p. 168. 
nombre en árabe en el texto principal, mientras que al dorso hay una pequeña nota en romance con la fecha, los testigos castellanos y los nombres de los alguaciles. Los alguaciles figuran como Aḥmad al-Šulmin/Ahamete Xulí y Muhammad al-Faqīh/Mahomad Alfaquí en el texto árabe y en la nota en castellano respectivamente. No existe empobrecimiento onomástico entre la fórmula árabe y la cristiana; simplemente se constata un acoplamiento algo forzado típico de la transliteración del árabe al romance (aunque en este caso sólo desaparece el artículo al del sobrenombre de uno de los alguaciles) ${ }^{36}$.

Sin embargo de los seis restantes individuos árabes que son reseñados en el texto principal (pero que no figuran en la nota castellana) ninguno tiene más de dos elementos en el nombre, a excepción de uno que lleva tres. ¿Estamos ante una reducción consciente del apelativo árabe, hasta en los documentos escritos en su mismo idioma? ¿Han padecido los granadinos al pasar de un régimen a otro una mediatización por parte de la administración castellana, aunque el escribano sea árabe y los textos escritos en su propio idioma? ¿O son otros los factores que debemos considerar?

En cuarto lugar, pese a ser expedidos en el periodo bisagra entre el fin del régimen nazarí en Granada y el de los Reyes Católicos antes de la conversión masiva, otra serie de documentos fechados en 1493 siguen sin distorsión los patrones árabes de las fórmulas jurídicas islámicas, y encontramos claras muestras de elasticidad en el sistema onomástico árabe. Estos documentos están compuestos de una citación al procedimiento de una causa civil escrita en árabe (con firma autógrafa de dos jueces islámicos) y su traducción castellana emitida el mismo día ${ }^{37}$.

Uno de los jueces es identificado en el texto de la citación con el nombre de Abū 'Abd Allāh Muhammad al Baqannī, pero este juez firma personalmente "Muhammad al Baqannī", obviando la kunya, mientras que en la traducción romance se transcribe como Mahomad el Pequeñí, limitándose a los dos elementos de la firma. Algo parecido tiene lugar con el otro juez, Abū Ya'far Aḥmad ibn 'Umar, que firma el texto como Aḥmad 'Umar, no sólo prescindiendo de la kunya sino también de la partícula ibn del nasab. De nuevo el patrón castellano sigue la fórmula autógrafa bajo la designación Hamed Omar. Finalmente, este patrón se repite con otro protagonista colaborador de los Reyes Católicos en este breve periodo de mudejarismo granadino, Yahyā al Nayyār, cuyos familiares y servidumbre se convierten en la parroquia de San Salvador del Albayzín en enero de 1500, según indican las nóminas que estudiamos. Mientras su nombre figura en el cuerpo del texto como Abū Zakariyyā Yahyā

36. M. Acién Almansa, «Dos textos mudéjares de la Serranía de Ronda (1491)», Cuadernos de Estudios Medievales, 2-3, 1974-1975, pp. 245-257.

37. Archivo de la Alhambra, Leg. 390, n. ${ }^{\circ} 42$; Leg. 388, n. ${ }^{\circ} 83$; y Leg. 388, n. ${ }^{\circ}$ 8, fechados el 23 de julio de 1493 y publicados en J.A. GARCíA LuJÁN y M. LÁZARO DURÁN, «Escrituras árabes granadinas y firma autógrafa de Abū Zakariyyā Yahyāa al Nayyār», Miscelánea de Estudios árabes y hebraicos, Sección Árabe-Islam, 54, 2005, pp. 79-99. 
al Nayyār, su firma se reduce al ism y al laqab de oficio, al igual que ocurre con el traslado del documento al castellano en el que figura como Yaya el Nayar haciendo desaparecer la kunya y limitando el apelativo a dos elementos.

\section{EL ANTROPÓNIMO ÁRABE EN LOS DOCUMENTOS NAZARÍES}

Existen documentos legales granadinos de la época nazarí (escrituras de compraventa, cartas de pago, escritura de partición de bienes) datados entre mediados del siglo XIV y mediados del XV, que sólo han sobrevivido en una versión romanceada efectuada en el siglo XVI por la vigencia de unos textos legales que requerían ser traducidos al castellano ${ }^{38}$.

El uso del nombre refleja una gran flexibilidad en sus formas en este conjunto de documentos relacionados entre sí y fechados de 1378 a 1422. A modo de ejemplo, estas son las formas en que aparece citado un mismo individuo en diversos documentos:

- Abdalla hijo de Abrahen Aben Abdulçamad el Azdi el Moxiqueri ${ }^{39}$.

- Abdalla ${ }^{40}$.

- Abdalla hijo de Abrehen Aben Abdulçamad Moxiquiri ${ }^{41}$.

- Abdalla hijo de Abrahan Aben Abdulçamad ${ }^{42}$.

- Abdalla el Moxiquiri ${ }^{43}$.

Aunque estas variantes constan en documentos independientes en su origen, se puede asumir que estaban vinculados entre sí, de forma que podían reducir el apelativo a un elemento después de figurar con su forma más compleja al darse por sentado la identidad del individuo en cuestión. Como se puede constatar, el nombre puede figurar con una gran combinación de elementos que, sin embargo, no responden forzosamente a necesidades documentales diversas: con el ism 'alam sólo; con ism + nisba geográfica; con ism + doble nasab; con ism + doble nasab + nisba geográfica; o con ism + doble nasab + nisba tribal + nisba geográfica.

38. Los documentos fueron traducidos por el oficial Juan Rodríguez. La traducción del nombre a veces roza una literalidad excesiva, como en el caso de un documento de partición de bienes de 1348, en el que la firma del alfaquí escribano figura de la siguiente manera: "Yahia hijo de Abdalla, hijo de Yahia, hijo de Abdalla Abenzacaria". Archivo del Colegio de San Bartolomé y Santiago de Granada (A.C.SB y SG), Ar. 4 Es. 5, Leg. 61, n. 2 (19 de febrero de 1561), publicado en M.J. Osorio Pérez y E. de SANTIAGo Simón, Documentos arábigo-granadinos romanceados, Granada, Centro de Estudios Históricos de Granada y su Reino, 1986, documento I, p.32.

39. A.C.SB y SG, Ar. 4 Es. 5, Leg. 61, n. ${ }^{\circ}$ 2, fols. 66r.-67v., ibídem, doc. 3.1, p. 49.

40. A.C.SB y SG, Ar. 4 Es. 5, Leg. 61, n. ${ }^{\circ}$ 2, fols. 69v.-71r., ibídem, doc. 3.9, p. 58.

41. A.C.SB y SG, Ar. 4 Es. 5, Leg. 61, n. ${ }^{o}$ 2, fols. 37r.-39v., ibídem, doc. 4.1, p. 63.

42. A.C.SB y SG, Ar. 4 Es. 5, Leg. 61, n. ${ }^{\circ}$ 2, fols. 58r.-58v., ibídem, doc. 6.1, p. 79.

43. A.C.SB y SG, Ar. 4 Es. 5, Leg. 61, n. ${ }^{\circ}$ 2, fols. 51v.-52r., ibídem, doc. 8.5, p. 96. 
No tendría sentido comparar las variantes onomásticas de los musulmanes granadinos sin consultar los documentos propiamente nazaríes (sin mediación de traductores) donde encontramos una amplia representación de individuos y sus diversas formas de identificación. El conjunto más amplio de documentos árabes granadinos del reino nazarí hoy conocido es el publicado y traducido por Seco de Lucena ${ }^{44}$. Muchos de los documentos son contratos de diversos tipos e incluyen un fondo antroponímico considerable. Asimismo, encontramos un uso variable del sistema onomástico árabe. A menudo figuran nombres con cadenas onomásticas muy dilatadas, pero en otras ocasiones no hay más que la mención de un simple elemento.

Aunque la onomástica femenina no está tan bien reflejada en la documentación nazarí como la masculina, los casos recopilados dan fe de una flexibilidad similar a la que se encuentra para los nombres masculinos. A modo de ejemplo, encontramos tres formas distintas del nombre de una misma mujer en tres documentos independientes relacionados con una herencia y fechados entre 1466 y 1467 :

— Umm al-Hasan bt. Abī Hadīd ${ }^{45}$.

— Umm al-Hasan bt. Abī-l-Haŷŷāŷy Yūsuf b. Abī Hadīd ${ }^{46}$.

— Umm al-Hasan bt. Yūsuf b. Abī Hadīd ${ }^{47}$.

En este caso encontramos variantes curiosas del ism + nasab simple y nasab doble. El nasab a veces refleja el ism simple del padre (Yūsuf) y en otra ocasión junto con su kunya (Abī-l-Haŷỹāŷy Yūsuf). Lo más sorprendente es que en las formas antroponímicas reducidas encontramos el salto de una generación en el nasab-Abī Hadīd es el abuelo pero figura en el primer documento en la posición de la cadena que identificaría al padre- lo que puede dar lugar a cierta confusión entre el que fuera padre y abuelo paterno de Umm al-Hasan (de ahí la necesidad de extremar la precaución en la determinación de la genealogía de un individuo).

No es el lugar aquí de analizar todas las estructuras onomásticas granadinas, pero saltan a la vista algunos patrones relevantes. En muchos casos debemos hablar de nombres interdependientes, sea como en el caso de los documentos que hemos expuesto, sea por la mención de individuos vinculados por relación familiar (normalmente paterna). Por ello, encontramos, por ejemplo,

44. L. SECO DE LuCENA, Documentos arábigo-granadinos, Madrid, Instituto de Estudios Islámicos, 1961; L. SECO DE LuCENA, «Documentos árabes granadinos II. Documentos de las Comendadoras de Santiago», Al-Andalus, vol. IX, 1944, pp. 121-140. Para toda la bibliografía y el estado de la cuestión ver C. BARCELÓ y A. LABARTA, «Los documentos árabes del reino de Granada. Bibliografía y perspectivas», Cuadernos de la Alhambra, 26, 1990, pp. 113-120.

45. Documento 21: declaración de herederos (diciembre de 1466), en L. SECO DE LUCENA, Documentos arábigo-granadinos..., pp. 46-47.

46. Documento 22: pliego particional (febrero de 1467), ibídem, p. 47.

47. Documento 23: demanda de herencia (diciembre 1467), ibídem, p. 49. 
a un individuo al que se menciona por su kunya $+i s m$, y que los restantes elementos de la cadena onomástica del individuo figuran en su relación estipulada como hijo de su padre, cuyo nombre aparece con otros elementos que vienen a vincularse por la cadena genealógica con el nombre del hijo ${ }^{48}$.

Sin embargo, en estos documentos nazaríes reparamos en otros casos que contienen más de dos elementos, e incluso, en otros ejemplos, al individuo se le denomina por un mero elemento aislado como un laqab o una nisba. Éstos raramente son los principales sujetos del contrato. Normalmente figuran como referencias secundarias, y en el caso de contratos de propiedad son los individuos cuya propiedad linda con aquella en cuestión pero que no se ven afectados por el trámite notarial ${ }^{49}$. Por consiguiente, si bien existen largas cadenas onomásticas en los documentos nazaríes, el apelativo árabe revela un amplio surtido de combinaciones y sugiere que la expresión onomástica viene determinada por la importancia del individuo, la facilidad con la que se le puede identificar, y especialmente su relevancia en el seno del documento.

\section{LA INHERENTE FLEXIBILIDAD DEL SISTEMA ONOMÁSTICO ÁRABE}

No todos los ejemplos nazaríes donde encontramos una larga cadena onomástica deben ser siempre considerados como la norma antroponímica. Asimismo, tampoco es cierto que todos los individuos de los textos clásicos árabes relacionados con la transmisión de las tradiciones lleven siempre apelativos con todos los elementos de la cadena onomástica árabe. A pesar de las largas cadenas típicas de los diccionarios bio-bibliográficos existen otras obras islámicas en las que los nombres no siempre se exhiben de forma extensa. Sublet establece un repertorio de formas de nombres para el Șaḥih de Buhāri del siglo IX donde se recopilan 7.000 transmisores cuyos nombres a menudo se reseñan con una forma abreviada, pero dentro de un contexto en el que son plenamente identificables: el ism solo; ism + nasab simple; ism + nasab doble; ism + kunya del padre; kunya sólo; el laqab (de mote) sólo; o la filiación por la que el individuo es más conocido. Sólo los nombres de los tradicionistas cuya identidad puede dar lugar a confusión son desarrollados con una larga cadena onomástica ${ }^{50}$. Sublet también hace hincapié en el hecho de que el tipo de documento a menudo determina la forma onomástica. A veces (en el caso de certificados y licencias) el

48. Ver por ejemplo el documento 8 de 1458, un pliego particional, en el que siempre se refiere al hijo de un tal Abū-l-Hasan 'Ali b. Ahmad b. Abī-l-Hasan, simplemente como el hijo Ahmad; L. SECO DE LuCENA, Documentos arábigo-granadinos..., pp. 20-22. Cabe esperar un estudio a fondo de la variabilidad de la onomástica árabe en los documentos nazaríes conservados al constituir un fondo suficientemente grande y variado para su investigación.

49. En el mismo documento citado anteriormente, dos individuos cuyas propiedades lindan con la que se pretende partir reciben la designación de Ibn Nuṣayr, y al-Ṭašamūs; ibídem, p. 21.

50. J. Sublet, Le voile du nom, pp. 126-130. 
nombre árabe medieval tomará formas más sintéticas. No es necesario expresar todo el nombre si con una parte basta para identificar a un individuo ${ }^{51}$.

Es a partir de esta realidad polimórfica, sin obviar otros factores mediáticos, como debemos entender la expresión del nombre árabe en los documentos del periodo de dominación cristiana, y en concreto los que nos conciernen directamente aquí, la nómina granadina de bautizos de 1500. El apelativo árabe que figura en la documentación mudéjar no necesariamente representa un acoplamiento artificioso del nombre original, ni un empobrecimiento onomástico debido a factores extrínsecos. Por el contrario, se debe considerar factible que represente en ciertos casos, más que una adulteración antroponímica, una forma concisa (aunque a veces romanceada) del sistema onomás-tico árabe tradicional.

\section{LA INEXTRICABLE RELACIÓN ENTRE LA LENGUA Y EL NOMBRE}

La degradación del sobrenombre árabe mudéjar en la mayoría de los reinos hispánicos y su sustitución por un equivalente onomástico romance en el siglo XV, a menudo se ha atribuido al hecho de que esta minoría estaba perdiendo el uso del árabe, si es que su idioma litúrgico no había caído ya completamente en el olvido. Cabe preguntarse si efectivamente existía un vínculo entre idioma y onomástica y cómo afectó a la comunidad mudéjar y más tarde a la morisca.

Aunque pervivieran reductos arabo-parlantes en casi todos los reinos hispánicos hasta el fin del mudejarismo, bien eran una exigua minoría, bien subsistían en limitadísimas zonas geográficas aisladas en el reino de Castilla, Aragón, Portugal y Navarra. Donde más pervivió el idioma entre la mayor parte de la población fue en la huerta de Valencia -por su aislamiento geográfico y una alta concentración demográfica- y en todo el reino de Granada, por su más reciente sometimiento al dominio cristiano y por ser la población musulmana -luego morisca- más numerosa de la Península ${ }^{52}$.

Los principales elementos identitarios de la comunidad mudéjar fueron la religión islámica, la lengua árabe y el origen común andalusí. Todo esto se podía expresar con una sola seña identitaria: el apelativo árabe ${ }^{53}$. La lengua

51. Ibídem, p. 137.

52. L. Bernabé Pons y M.J. Rubiera Mata, «La lengua de mudéjares y moriscos. Estado de la cuestión», Actas del VII Simposio Internacional de Mudejarismo, Teruel, Centro de Estudios Mudéjares, 1999, pp. 599-631; L.P. HARVEY, «Los muslimes de España y sus idiomas en la época de Colón», en R. Penny (ed.), Actas del Primer Congreso Anglo-Hispano, tomo I: Lingüística, Madrid, 1993, pp. 37-47; J.-P. MolÉNAT, «L'arabe à Tolède du XII au XVI ${ }^{\mathrm{e}}$ siècle», Al-Qanțara, XV, Madrid, 1994, pp. 473-496; L. CARDAILLAC, «Les morisques et leur langue», Cahiers d'Études Romanes, 16, 1990, pp. 1-25; para el caso portugués, M.F. LOPES DE BARROS, «The Identification of Portuguese...», pp. 203-204.

53. M. de EpAlzA, «L'identité onomastique et linguistique des Morisques», Religion, Identité et Sources Documentaires sur les Morisques Andalous, vol. 1, Túnez, 1984, pp. 269-279. 
árabe, más que un idioma cotidiano, fue la lengua sagrada, aunque el hecho de que otras lenguas sean lícitas en el Islam probablemente permitió cierto ajuste entre los mudéjares que lentamente perdieron el uso del árabe ${ }^{54}$.

A pesar de la relativa escasez de documentación sobre individuos mudéjares (al menos en el caso castellano) se ha podido recoger cierto acopio onomástico de los súbditos musulmanes de los reyes hispánicos que permite una relativa aproximación a la antroponimia mudéjar. Constatamos una decadencia lingüística generalizada del antropónimo mudéjar árabe en el caso de los sobrenombres (los ism 'alam de los mudéjares se analizarán en contraste con los de la nómina granadina más adelante). Si examinamos el caso probablemente más afectado por la pérdida de la lengua autóctona de las comunidades mudéjares -el del reino de Castilla- sobresale el hecho de que la inmensa mayoría de los que constan con sobrenombre utilizan un apelativo en lengua romance. Sólo constan menos de un 15\% con un sobrenombre en lengua árabe para la comunidad mudéjar de Uclés ${ }^{55}$, un cuarto del colectivo musulmán del Campo de Calatrava ${ }^{56}$ y algo menos de un tercio de los mudéjares de Sevilla ${ }^{57}$. Aunque es preciso ser cauteloso por las limitaciones cuantitativas de estas muestras, posiblemente la pérdida de la lengua en este caso conlleva una directa relación con cierta transformación antroponímica.

\section{SOBRE EL NOMBRE MOZÁRABE EN EL CONTEXTO CASTELLANO-LEONÉS}

El otro caso de singularidad onomástica que igualmente bebe de ambas tradiciones lingüísticas peninsulares -la latino-romance y la árabe- es el de los mozárabes, específicamente en el contexto toledano después de la conquista castellano-leonesa ${ }^{58}$. En un primer momento, como ya señaló González Palencia, empezamos a encontrarnos una duplicidad en el nombre de los an-

54. B. VINCENT, «Los moriscos y los idiomas árabe, castellano y catalán», en E. LORENZO SANZ (coord.), Proyección histórica de España en sus tres culturas: Castilla y León, América y el Mediterráneo, I, Valladolid, Junta de Castilla y León, 1993, pp. 369-378.

55. Se ha calculado a partir de en una muestra de 63 individuos de la nómina publicada en $\mathrm{M}$. GARCíA-ARENAL, «Dos documentos sobre los moros...».

56. El cálculo está basado en una muestra de 45 individuos con sobrenombre en el repertorio de mudéjares publicado en M.F. GÓMEz VOZMEDIANo, Mudéjares y moriscos en el Campo de Calatrava. Reductos de convivencia, tiempos de intolerancia (siglos XV-XVII), Ciudad Real, Biblioteca de Autores Manchegos, 2000.

57. El cómputo se ha efectuado siguiendo el padrón de 32 individuos (de los cuales sólo 25 tienen sobrenombres) publicado en K. WAGNER, op. cit.

58. Existen otros casos interesantes de nóminas de designaciones árabes (sean los individuos cristianos mozárabes o árabes islámicos), a veces con elementos híbridos, transcritos en documentos en latín que han sido el objeto de ciertos estudios. Ver por ejemplo, R. HiтCHCOCK, «Arabic proper names in the Becerro de Celanova», en D. HOOK y B. TAYLOR (eds.), Cultures in Contact in Medieval Spain: Historical and Literary Essays Presented to L.P. Harvey, Londres, King's College Medieval Studies, 1990, pp. 111-126. 
tiguos cristianos arabizados de Toledo. El nombre puede designarse en latín (transcrito al alifato si el documento está redactado en árabe) o en árabe (transcrito al alfabeto latino si el documento está en latín), o pueden incluirse ambas versiones en un documento monolingüe para eliminar cualquier duda sobre la identidad del individuo en cuestión ${ }^{59}$.

No obstante, a pesar de esta evidente duplicidad del nombre íntegro, es poco frecuente en la documentación de la época. Lo que se constata en un número considerable de casos entre los mozárabes toledanos, al menos hasta finales del siglo XII, es el desdoblamiento del primer nombre con la opción latinoromance (nombre de pila) y la opción árabe (ism), o fórmulas donde predomina un nombre latino-romance con un sobrenombre árabe o con una estructura árabe $^{60}$. Este sincretismo onomástico se irá difuminando a medida que vaya desapareciendo el idioma árabe entre las nuevas generaciones de mozárabes ${ }^{61}$.

Es difícil obviar que estas fórmulas sincréticas evocan de alguna forma la onomástica morisca donde persiste, por una parte, el sistema dúplice al menos con el nombre de pila y el ism y, por otra, estructuras mixtas en el sobrenombre oficial. Sin embargo, existieron diferencias insoslayables. El factor divergente crucial está por un lado en el carácter lícito de la síntesis onomástica mozárabe y, por otro, en el hecho de que la pervivencia árabe en el apelativo de esta comunidad se atribuye a un orgullo cultural árabe y a una necesidad de mantener un distintivo que identifique la pertenencia a una civilización ilustre. Para los moriscos, el uso del ism y del sobrenombre árabe era probablemente una forma de mantener viva no sólo la cultura de al-Andalus sino también su adscripción a la umma aunque, como veremos más adelante, no siempre era tan evidente.

\section{LAS MEDIDAS CONTRA EL ANTROPÓNIMO ÁRABE DE LOS MORISCOS}

Las autoridades castellanas no llegaron a un consenso sobre el impacto de la pervivencia del árabe entre los moriscos. Sin embargo, a pesar de los puntos de vista encontrados, casi todos estaban de acuerdo en que el objetivo final fuera una asimilación total que exigiría la erradicación del árabe. Hasta el mismo arzobispo de Granada, Talavera, uno de los más indulgentes con los granadinos en su tarea evangelizadora y el que más hizo para crear un plan de catequesis con

59. A. GonZÁlez Palencia, Los mozárabes de Toledo en los siglos XII y XIII, Madrid, Instituto Valencia de Don Juan, 1930, vol. preliminar pp. 123-129. Ver también el análisis onomástico llevado a cabo en J.-P. MolénAT, «L'onomastique tolédane...», pp. 169-173.

60. “Estas fluctuaciones en materia tan fundamental como el nombre [...] quieren decir bien claramente que los nombres cristianos eran algo como pegadizo, puesto que en la vida familiar y social, en los casos solemnes cuando había de surtir efecto la personalidad, había que advertir que aquel hombre era llamado de otra manera, a la arábiga". L.A. GONZÁlEZ PALENCIA, op. cit., p. 124. Ver también, J.-P. MolÉNAT, «L'onomastique tolédane...», p. 170.

61. A. GonZález Palencia, op. cit., p. 129. 
misioneros que pudieran comunicarse en la lengua autóctona de los moriscos granadinos, incitó a sus nuevos fieles inmediatamente después de la conversión a tomar medidas para abandonar el uso de su lengua materna lo antes posible ${ }^{62}$.

Las medidas políticas adoptadas para prohibir el uso público y privado del árabe por parte de los moriscos comenzaron a partir de $1526^{63}$. Se irán reiterando con mayor o menor vehemencia en Granada hasta la expulsión de los moriscos de su tierra. No obstante, debido en parte a las constantes derogaciones temporales, la falta de medios para implementar estas medidas y el hecho de que erradicar la lengua de un colectivo numeroso en cuestión de pocos años con la mera fuerza de la ley sea antropológicamente cuestionable, la tentativa fracasó estrepitosamente ${ }^{64}$.

La misma contundencia teórica y su paralela tibieza práctica ante el idioma se calcarían para las normativas que intentaron reprimir el uso de los vestigios de la onomástica árabe. En primer lugar, las restricciones atañen exclusivamente a lo que incumbe a la Iglesia: la utilización de un nombre personal no-cristiano. Por consiguiente, resulta algo contradictorio el uso reiterativo en los documentos oficiales del nombre previo a la conversión junto con el nuevo nombre recibido durante el bautizo durante la primera década tras la conversión de 1499-1500 en el caso de Granada. En un documento (circa 1505) sobre pagos a los antiguos alfaquíes granadinos ya convertidos, constatamos este patrón onomástico: “Francisco Ximénez que solía ser llamado Mahoma Abencob", o "Alonso Vanegas hera llamado alfaquy Adalaziz"65.

Esta persistencia documental del nombre musulmán junto con el nombre cristiano no es tan atípica como podría creerse a partir de la segunda mitad del siglo XV y se constata en diversos casos anteriores. Uno de ellos es el de la guardia morisca en época de Juan II y Enrique IV. Muchos caballeros musulmanes se

62. "Mas para vuestra conversaçion sea syn escandalo a los christianos de naçion y non piensen que aun teneys la seta de Mahomad en el coraçon es menester que vos conformeys en todo y por todo a la buena y honesta conversaçion de los buenos y honestos christianos y christianas en vestir y calçar y afeytar, y en comer y en mesas y viandas guisadas como comunmente las guisan y en vuestro andar y en vuestro dar y tomar y mucho y mas que mucho en vuestro hablar, olvidando quanto pudieredes la langua araviga y faziendola olvidar y que nunca se hable en vuestras casas. Y porque para que algunos guarden las cosas susodichas sera menester alguna premia...", Archivo General de Simancas (AGS), Diversos de Castilla, L. 8, fol. 114, publicado en M.A. Ladero Quesada, Granada después de la conquista: Repobladores y Mudéjares, Granada, Diputación Provincial de Granada, 1993, doc. 127, pp. 545-548.

63. Ver Cédula de la Capilla Real: A.I.C.G., Reales Cédulas, lib. II duplicado, fol. 70, publicado en A. GAllego Burín y A. GAMIR SANDOval, Los moriscos del reino de Granada según el sínodo de Guadix de 1554, Granada, Universidad de Granada, 1968, p. 202.

64. Según Vincent, las medidas legales no fueron más que amenazas sin consecuencias: B. VINCENT, op. cit., p. 369.

65. Archivo General de Simancas, Sección: Diversos de Castilla, libro 8, fol. 123, publicado en J. AlbarRacín NAVARRO, «Memorial a propósito de los alfaquíes de la Granada mudéjar», en C. del Moral (ed.), En el epilogo del Islam andalusi: La Granada del siglo XV, Granada, al-Mudun, 2002, pp. 303-305. 
convirtieron al cristianismo pero no siempre se les suprimió su identidad previa. La verdad es que no interesaba borrar su adscripción a otra cultura. El propósito mismo de los reyes era tener un cuerpo de elite extranjero (la mayoría provenían del reino nazarí) para que sus componentes pudieran mantenerse al margen de las alianzas de linajes nacionales que amenazaban con traicionar al monarca. Era preciso recalcar la diferencia para no fomentar la aculturación y así evitar que se inmiscuyeran en las conspiraciones que hostigaron a estos dos reyes ${ }^{66}$. No obstante, cabe preguntarse por qué se reprodujo este patrón en el caso de las conversiones masivas de Granada, caso que ostensiblemente no se inserta dentro de la lógica de la diferenciación de la guardia morisca ${ }^{67}$.

Podemos adelantar que esta paradoja de perpetuar el doble nombre musulmán y cristiano se constata, como veremos, en las mismas nóminas de bautizos cuando se vuelve a hacer mención de un individuo, ya bautizado, por su nombre árabe. Subyace una cuestión práctica al permitir un periodo de gracia hasta que la nueva identidad, el nuevo apelativo, queden fijados. Para usos administrativos, mediaría la necesidad de garantizar la adecuada identificación del individuo en cuestión; razón por la cual contamos con abundantes documentos con el doble nombre cristiano seguido del ism y a veces de un sobrenombre árabe.

Posiblemente, influiría también esa contradicción -inspirada en el espíritu de limpieza de sangre- de querer identificar a un individuo por su ascendencia musulmana, para evitar la eventual confusión entre nuevos y viejos cristianos. Sean cuales fueran las motivaciones, no deja de resultar anómalo que la administración perpetúe documentalmente el uso del sistema onomástico dúplice y al tiempo amenace con sanciones a los moriscos que hicieran lo mismo en su vida privada. No obstante, a partir de 1510 este fenómeno documental del antropónimo dúplice empieza a hacerse cada vez más raro en el contexto granadino ${ }^{68}$.

Es precisamente en esta fecha cuando se empieza a legislar contra diversos aspectos de la libertad de los moriscos. En 1510, por primera vez, los cristianos nuevos son diferenciados de jure de los cristianos viejos al ser sometidos aquéllos de forma casi exclusiva al sistema impositivo de la farda mayor ${ }^{69}$. A

66. A. Echevarría Arsuaga, Caballeros en la frontera. La guardia morisca de los reyes de Castilla (14101467), Madrid, UNED, 2006, pp. 147-153; y colección documental, pp. 203-279.

67. Otro ejemplo de conversos del Islam cuya personalidad onomástica árabe es conservada junto con la cristiana durante un periodo de transición es el caso de Galicia durante el siglo XII y XIII estudiado por J. GAUTIER DALCHÉ, «Les sarrasins du monastère de Sobrado», en Minorités et marginaux en France et dans la péninsule ibérique (VII-XVIII siècles. Actes du Colloque de Pau 27-29 mai, 1984, Paris, Édition CNRS, 1986, pp.71-88.

68. A. Domínguez Ortiz y B. Vincent, Historia de los moriscos. Vida y tragedia de una minoría, Madrid, Biblioteca de la Revista de Occidente, 1978, p. 102.

69. La farda menor o farda de la mar, sin embargo, sí fue impuesta a todos los cristianos sin distinción. Ibídem, p. 23. Ver también la discusión sobre lo que Galán Sánchez denomina una fiscalidad diferencial en A. GALÁN SÁNCHEZ, «De mudéjares a moriscos: los problemas metodológicos de una transición», en M. BARrios AgUILERA y A. GALÁn SÁNCHEZ (eds.), La historia del reino de Granada a debate. Viejos y nuevos temas. Perspectivas de estudio, Málaga, CEDMA, 2004, pp. 314-317. 
partir de este momento empiezan a recrudecerse las normas contra los signos externos de pertenencia a un colectivo que será desde sus inicios y sin tregua sospechoso de prácticas cripto-musulmanas. No obstante, la práctica de las autoridades castellanas de distinguirlos, por una parte, y aprobar medidas contra su alteridad para forzar una asimilación total, por otra, refleja una inherente contradicción tan categórica que haría cada vez más enrevesada la integración de los moriscos ${ }^{70}$. Esta posición irreconciliable llevaría a los moriscos (y sobre todo a los que no necesariamente fueron cripto-musulmanes de conciencia) hacia una anomia social que, entre otras consecuencias, se traduciría en una creciente ambigüedad onomástica.

Las normas que se establecieron contra el ism serían acompañadas de otras contra el sobrenombre por primera vez en 1526, con las medidas de la Capilla Real. Estas normativas ya no iban expresamente contra lo dictado por el estamento religioso al ser los sobrenombres meros adiaphora (es decir, características diferenciales que no atentan contra la ortodoxia cristiana), sino más bien se insertan en una larga ristra de medidas contra las señas de identidad más visibles ${ }^{71}$. El nombre junto con el idioma, las tradiciones, la vestimenta y otros signos externos que hacían evidente la alteridad morisca, se convirtieron en nuevo caballo de batalla de las autoridades castellanas ${ }^{72}$.

No obstante, el golpe definitivo vino de las recomendaciones de los prelados que surgieron del sínodo provincial de Granada en 1565 y que, junto con las deliberaciones que tuvieron lugar un año más tarde en Madrid, dieron paso a la pragmática publicada en 1567. Estas normas volvieron a prohibir todo aquello que se había dispuesto anteriormente y que posteriormente se había aplazado de forma indefinida, pero ya no cabía el tono conciliador que caracterizó a muchos de los dictámenes previos. No obstante, los moriscos no parecen haber perdido la esperanza de poder lograr aplazar una vez más las medidas con cier-

70. Harvey afirma, "On the Christian side, there was a great theoretical longing to have the conversions become a reality and, at the same time, no practical desire to have these people in any but a menial place on the margins of society", L.P. HARVEY, Muslims in Spain 1500-1614, Chicago, The University of Chicago Press, 2005, p. 238. Ver también, A. GALÁN SÁNCHEZ, «Segregación, coexistencia, y convivencia: algunas notas sobre los musulmanes en la ciudad de Granada (14921570)», en M. BARrios Aguilera y J.S. GONZÁlez AlCANTUd (eds.), Granada en el V Centenario. Granada, Universidad de Granada, pp. 340-342. Sobre los antecedentes medievales de la acometida institucional contra la alteridad, ver, R.I. MOORE, The Formation of a Persecuting Society. Power and Deviance in Western Europe, 950-1250, Oxford, Blackwell, 1987.

71. “Asimismo somos informados que algunos de los nuevamente convertidos se llaman nombres y sobrenombres de moros; mandamos que de aquí adelante no se lo llamen, y si alguno de ellos tiene agora nombre o sobrenombre que suene a moros, lo quite y no se lo llame más y tome otro nombre de cristiano", A.I.C.G., Reales Cédulas, lib. II duplicado, folio 70, publicado en A. GALLEGO Burín y A. GÁMIR SANDOVAL, op. cit., pp. 204-205.

72. A. GALÁN SÁNCHEZ, «Los moriscos del reino de Granada. De las capitulaciones de la conversión a las medidas de la Capilla Real», Actas del III Coloquio de Historia Medieval Andaluza, Jaén, 1984, pp. 90-98. 
ta maña negociadora y alguna concesión financiera ${ }^{73}$. Una vez más, tanto los nombres como los sobrenombres de moros fueron explícitamente proscritos ${ }^{74}$.

Es en este momento cuando el portavoz por excelencia de los agravios moriscos, Francisco Núñez Muley, lanzará su última elocuente protesta contra estas restricciones, incluyendo las onomásticas. Al margen de la radicalidad de su discurso (no hay que perder de vista que pone en tela de juicio la misma licitud de los bautizos forzados contra lo capitulado por los Reyes Católicos, aunque acepte la irreversibilidad de la conversión), clamará en todo momento por el derecho de llevar el sobrenombre árabe al no verse éste reñido con ningún presupuesto teológico. En ningún momento cuestiona abiertamente la prohibición del uso del ism árabe, pero al final de su memorial, el portavoz morisco hará un tour de force discursivo apelando a la compasión tanto como a la razón de los cristianos viejos pidiéndoles que se metan en la piel de los moriscos por un instante. Núñez Muley les pregunta cómo se sentirían si fueran expuestos a las mismas medidas coercitivas que ellos padecían, en donde se les exigía que cambiaran toda su forma de ser, de hablar, de celebrar, de identificarse, de relacionarse de la noche a la mañana... Es en su conclusión donde el antiguo paje del arzobispo Talavera menciona lo absurdo que supone ser obligado a cambiar de sobrenombre $y$ de nombre ${ }^{75}$. Sin necesidad de leer más allá de lo que explicita el texto, es relevante destacar que la crítica -velada o inconsciente- de la negación de la identidad expresada a través de todos los elementos onomásticos árabes, incluyendo el ism, sea insinuada por un morisco cuya sincera adscripción al cristianismo nunca se había puesto en duda.

\section{LA NÓMINA DE BAUTIZOS DE 1500}

\section{EL CONTEXTO Y EL PROBLEMA METODOLÓGICO}

La nómina de bautizos de 1500 se presenta como un vasto elenco lacónico de nombres musulmanes seguido del nuevo apelativo cristiano ${ }^{76}$. Asimismo,

73. A. Domínguez Ortiz y B. Vincent, op. cit., pp. 32-33.

74. "Cuanto a los nombres, ordenaron que no tomasen, tuviesen ni usasen nombres ni sobrenombres de moros, y los que tenían, los dexasen luego...", publicado en A. GALlego Burín y A. GÁmiR SANDOVAL, op. cit., p. 274.

75. F. NúÑEZ MuleY, «Memoria», de la edición de R. Foulché-Delbosc (publicada originalmente en la Revue Hispanique, 6, 1899, pp. 205-239), reeditada en A. GALLEGO Burín y A. GÁMIR SANDOVAL, Los moriscos del reino de Granada según el sínodo de Guadix de 1554, estudio preliminar de B. VINCENT, Granada, Archivum, 1996, p. LII. (Todas las referencias aquí citadas son de la reedición de Foulché-Delbosc, aunque existe también la versión y el estudio de K. GARRAD, «The Original Memorial of Don Francisco Núñez Muley», Atlante, II, 4, 1954, pp. 197-226.)

76. La muestra que hemos seleccionado es el registro de los bautizos masivos que tuvieron lugar en la primera mitad del mes de enero de 1500 en las parroquias de San Salvador y de Santa Isabel (además de una pequeña muestra de San Andrés) con un total de 1.629 referencias a individuos (1.376 bautizados y 253 ausentes que son aludidos por relación a los conversos). 
incluye ocasionalmente alguna que otra información relativa a la estructura familiar, la edad, la profesión, algún título, la dirección de la morada, o alguna característica física, pero nunca todos estos datos juntos ${ }^{77}$.

El bautismo es el primer sacramento al que accede el cristiano, sea recién nacido, sea converso. El otorgamiento de un nombre propio es el símbolo de la consagración del niño, o neófito, a Dios; de ahí que el rito no sea exclusivamente una inmersión en el agua bautismal, sino que al implicar una nueva vida, se imponga una nueva designación ${ }^{78}$. A partir de finales de 1499, ante la decisión de la conversión incondicional de toda la comunidad de la capital granadina después del alzamiento del Albayzín, era imperativo que el proceso fuera acompañado de una transformación que incluyera los nombres de todos los musulmanes que formalmente se adherían a la nueva fe.

Los nombres islámicos eran en su mayoría desconocidos para los escribanos que tenían la laboriosa tarea de anotar aquello que oían. Debido al divergente sistema fonético entre el árabe y el castellano debieron efectuar una transliteración aproximada y, en muchos casos, harto deficiente. Por ello, casi todos los nombres que figuran en la lista cuentan con más de una versión ortográfica, incluso en el caso de los nombres más comunes. Aun para estos nombres más conocidos encontramos una infinita variedad ortográfica, lo que demuestra que los escribanos generalmente no se remitieron a una versión homogénea -aunque igualmente arbitraria- de cada nombre, sino que intentaron ser fieles, en la medida de lo posible, los fonemas que vocalizaban los bautizados. El ejemplo más extremo -aunque por otras razones- es el del nombre del profeta islámico, Mahoma/Muhammad, que en las nóminas figura con nada menos que 19 versiones distintas ${ }^{79}$.

La primera cuestión que debemos aclarar es quién concedió el nuevo nombre cristiano a los granadinos en 1499-1500. En el caso de Santa Isabel, conocemos tanto la identidad del sacerdote que oficia el rito (el racionero Diego de Baeza), como el hombre que intervino como padrino (Juan de Medina); para San Salvador sólo conocemos al responsable del sacramento (el licencia-

77. Por ejemplo, en el asiento 151 encontramos, "Mahomad Xibili alvardero llamose Juan"; en el asiento 779, "Maçoda negra llamose Francisca"; en el 1254, "Hamete Yaça ollero casado de 28 años, Bartolomé"; y en el 1283, "Axa muger de Juan Molinero, ella de 35 años, María”.

78. B. NeunHeuser, Historia de los dogmas. Bautismo y confirmación, Tomo IV, Cuaderno 2, Madrid, Biblioteca de Autores Cristianos, 1974, pp. 90-106.

79. El caso del nombre de Muhammad es excepcional debido en parte al carácter sagrado del nombre del profeta y la necesidad que existía de evitar la pronunciación formal de este ism para no invocar directamente al mensajero del Islam. Sobre esta cuestión y las variantes del nombre Muhammad ver F. de la GRANJA, «A propósito del nombre Muhammad y sus variantes en occidente», Al-Andalus, 33, 1968, pp. 231-240. Ver también la discusión de esta cuestión en M. de EPALZA, «Bibliografía hispànica sobre Aràbia, Mahoma (Muhammad) i l'Alcorà», en M. de EPAlZA, L'Alcorà. Traducció de l'àrab al català, introducció a la lectura i cinc estudis alcorànics, Barcelona, Proa, 2001, pp. 1008-1013. 
do de Parra). Es muy probable que fueran estos individuos los que otorgaron la inmensa mayoría de los nombres cristianos.

En algunos casos, encontramos ciertos comentarios que revelan la expresa voluntad del neófito de elegir su nombre: cinco en el elenco de nombres masculinos ${ }^{80}$, y ocho en el femenino ${ }^{81}$. Además, se puede constatar que en cuatro casos los nombres están tachados en la nómina y se especifica otro en su $\operatorname{lugar}^{82}$. Esta corrección no indica necesariamente que el bautizado no estuviera conforme con el nombre y propusiera una alternativa en última instancia, pero es muy probable. De cualquier manera, son tan escasos los indicios de la intervención de los neófitos que, en líneas generales, induce a concluir que en la mayoría de los casos los nombres no eran elegidos por ellos mismos.

Debemos también considerar el relativo desconocimiento del idioma castellano habida cuenta de la esporádica interacción que habrían tenido los granadinos con los castellanos en los escasos ocho años transcurridos desde la conquista y en un contexto -el de Granada capital-donde los musulmanes seguían siendo demográficamente mayoritarios. Estos factores habrían favorecido un exiguo conocimiento de la onomástica cristiana por los oriundos de la ciudad y, debido a la relativa variedad de nombres castellanos que figuran en las nóminas, debemos dar por hecho que los nombres de pila fueron impuestos casi exclusivamente por los castellanos que administraron el bautismo.

Al margen del nombre, en algunos asientos de la nómina también se proporcionó información -como hemos mencionado- relativa a otras características personales de los granadinos. Estos datos (sobre todo, los relacionados con los oficios) no hubieran podido ser recabados sin que alguien mediara como traductor, teniendo en cuenta que el castellano era desconocido hasta por algunos de los más estrechos colaboradores granadinos de los Reyes Católicos ${ }^{83}$. No hay mención a ningún trujamán en las nóminas de bautizos, pero éstas no siempre recogían la noticia de todos los que estaban presentes en el sacramento. Posiblemente algunos de los que administraron el bautismo pudieron haber formado parte del equipo del arzobispo Talavera, quien se ocupó de que aprendieran al menos los rudimentos de la lengua árabe para las misiones en Granada. De cualquier modo, no parece haber mediado una barrera lingüística adversamente en este multitudinario proceso que se llevó a cabo en muy pocos días.

Sin duda, el problema sobre la mediatización del nombre musulmán, sea en este caso de la conversión general de los granadinos o en las referencias de

80. Los asientos masculinos corresponden a [833], [954], [1137], [1143], [1162].

81. Los asientos femeninos corresponden a [919], [934], [1126], [1139], [1140], [1149], [1160], [1234].

82. Los cuatro asientos donde se encuentra el nombre tachado y reemplazado por otro corresponden a [155], [412], [440], [978].

83. A. Galán SÁnchez, Los mudéjares del Reino de Granada, Granada, Universidad de Granada, 1991, p. 272. 
los mudéjares en documentos latino-romances de los reinos peninsulares, debe considerarse como factor potencial de distorsión onomástica ${ }^{84}$. Por ejemplo, cuando figura junto al ism, el sobrenombre en la nómina está compuesto de un solo elemento, reduciendo la larga cadena onomástica tradicional meramente a dos elementos, sin excepciones. No obstante, el debate sobre el nombre auténtico se tratará más adelante con respecto a los sobrenombres, que son los que pueden suscitar más sospecha de estar adulterados por el filtro de los escribanos castellanos.

El caso del repertorio del ism árabe de los granadinos nos proporciona un retrato onomástico muy valioso por el mero hecho de reflejar de forma relativamente objetiva la realidad de una población que incluye ambos sexos y todos los escalafones sociales, aspectos que obvian -por razones documentales fundamentalmente- la mayoría de los estudios onomásticos árabes. El único factor que podría distorsionar la muestra es la emigración de parte de la población desde 1492. Es cierto que aquéllos que optaron por salir del reino de Granada a raíz de la conquista de los Reyes Católicos, generalmente contaron con los medios para hacerlo, aunque no hay que olvidar que en un primer momento todos los que eligieron el exilio voluntario lo hicieron sin tener que pagar los costes de transporte marítimo según las condiciones estipuladas por las nuevas autoridades castellanas ${ }^{85}$. Si bien la mayoría de la jāș̣̦a partió en los primeros años del dominio cristiano, hubo sectores de la elite administrativa que permanecieron al menos hasta el momento posterior a la conversión. En suma, habría que matizar que la muestra en cuestión, si acaso, adolece de cierta infra-representación de la clase vinculada a los linajes de la corte y quizás de una ligera sobre-representación de las clases más humildes ${ }^{86}$; en cualquier caso, de toda la documentación que ha sobrevivido es probablemente la fuente más representativa de lo que fuera la 'āmma nazarí en sus epígonos.

\section{EL ANÁLISIS ANTROPONÍMICO DEL ISM 'ALAM EN LA NÓMINA DE 1500}

Como se puede constatar en el listado del ism masculino (cuadro 1), hay un total de 53 nombres originales, de los cuales 25 figuran más de una vez. Es posible que de los 28 restantes, algunos sean hipocorísticos o versiones de los nombres que no son fáciles de deducir con toda seguridad. Algunos de los

84. J.-P. MOLÉnAT, «L'onomastique tolédane...», p. 168; P. GUICHARD, op. cit., p. 121; y C. LALIENA CORBERA, op. cit., p. 146.

85. M.A. LADERO QueSADA, Los mudéjares de Castilla en tiempos de Isabel I, Valladolid, Instituto "Isabel la Católica" de Historia Eclesiástica, 1969, p. 34

86. Pese a esta cautela metodológica, el estudio de las referencias sobre los oficios de los individuos de esta muestra proporciona un cuadro laboral muy variado donde predomina el ramo artesanal como era de esperar en una urbe musulmana de finales del siglo XV. Para el estudio detallado de los oficios de esta población ver G. CARRASCO GARCía, op. cit., pp. 356-361. 
Cuadro 1. Nombres masculinos árabes (ism 'alam) de Granada (1500) ${ }^{87}$.

\begin{tabular}{|c|c|c|c|c|}
\hline & ISM 'ALAM & FRECUENCIA & $\%$ ACUMULADO & CASOS \\
\hline 1 & Mahomad [Muhammad] & $39,31 \%$ & 38,51 & 285 \\
\hline 2 & Hamet [Ahmad] & $16,96 \%$ & 56,27 & 123 \\
\hline 3 & Ali ['Alī] & $14,07 \%$ & 70,34 & 102 \\
\hline 4 & Caçin [Qāsim] & $5,93 \%$ & 75,97 & 43 \\
\hline 5 & Abraen [Ibrāhīm] & $4,69 \%$ & 80,66 & 34 \\
\hline 6 & Çad [Sa'd] & $2,76 \%$ & 83,42 & 20 \\
\hline 7 & Abdalla ['Abd Allāh] & $2,76 \%$ & 86,18 & 20 \\
\hline 8 & Abulcaçim [Abū l-Qāsim] & $1,24 \%$ & 87,42 & 9 \\
\hline 9 & Farax [Faraŷ] & $1,10 \%$ & 88,52 & 8 \\
\hline 10 & Maçot [Mas'ūd] & $1,10 \%$ & 89,62 & 8 \\
\hline 11 & Yça ['Īsà] & $0.83 \%$ & 90,45 & 6 \\
\hline 12 & Ubecar [Abū Bakr] & $0,69 \%$ & 91,14 & 5 \\
\hline 13 & Muça [Mūsà] & $0,55 \%$ & 91,69 & 4 \\
\hline 14 & Yuçuf [Yūsuf] & $0.55 \%$ & 92,24 & 4 \\
\hline 15 & Çali [Ṣāliḥ] & $0,41 \%$ & 92,65 & 3 \\
\hline 16 & Fadar [Faḍl] & $0,41 \%$ & 93,06 & 3 \\
\hline 17 & Abulfar [Abū l-Bahār?] & $0,28 \%$ & 93,34 & 2 \\
\hline 18 & Adarramen ['Abd al-Raḥmān] & $0,28 \%$ & 93,62 & 2 \\
\hline 19 & Azen [Hasan?] & $0,28 \%$ & 93,90 & 2 \\
\hline 19 & Faxer ['Ašir?] & $0,28 \%$ & 94,18 & 2 \\
\hline 20 & Canbili [Kāmil?] & $0,28 \%$ & 94,46 & 2 \\
\hline 21 & Çayit [Sa'īd] & $0,28 \%$ & 94,74 & 2 \\
\hline 22 & Mançur [Manșūr] & $0,28 \%$ & 95,02 & 2 \\
\hline 23 & Mofarax [Mufarriŷ] & $0,28 \%$ & 95,30 & 2 \\
\hline
\end{tabular}

87. Los nombres que figuran en el cuadro incluyen las siguientes variaciones en la transliteración del árabe al castellano: Abraen incluye Abrahen, Abrahin, Abrahym, Abrayn. Hamete incluye Hamet, Hamed, Amet, Amete. Abdalla incluye Avdal, Avdala, Avdalafe, Avdalla. Azen incluye Façen. Abulcaçin incluye Abulaçin, Bulcaçin, Bularçin, Bulcacim. Caçin incluye Caçen, Caçini. Çayd incluye Çayit. Çad incluye Çadi. Çali incluye Çale. Maçot incluye Maçod, Maçar, Maçote. Muça incluye Muza. Ubecar incluye Ubeque, Hobeque, Obacar. Yusuf incluye Yuçef. Yça incluye Ynça, Ynçafa. Mahomad incluye Mahama, Mahamad, Mahamat, Mahame, Mahamed, Mahamen, Mahamet, Mahoma, Mahomat, Mahomed, Mahomet, Mahuma, Mohamad, Mohamed, Muhamad, Muhamed, Muhamet, Muhoma. Se ha optado en el cuadro por la forma más común reflejada en las nóminas y entre paréntesis se ha incluido la versión árabe más próxima, aunque algunas equivalencias no dejan de ser dudosas. 


\begin{tabular}{llccc}
\hline & ISM 'ALAM & FRECUENCIA & $\%$ ACUMULADO & CASOS \\
\hline 24 & Omar ['Umar] & $0,28 \%$ & 95,58 & 2 \\
25 & Reduan [Riḍwān] & $0,28 \%$ & 95,86 & 2 \\
& Otros $^{88}$ & $4,64 \%$ & 100,00 & 28 \\
\hline Total & $\mathbf{1 0 0 , 0} \%$ & & 725 \\
\hline
\end{tabular}

nombres que figuran una sola vez -los hapax ${ }^{89}$ - en algún caso pueden ser apellidos, sobrenombres, o incluso apodos. La concentración onomástica masculina que resulta del cómputo es de un nombre por algo menos que cada 14 varones.

\section{Cuadro 2. Nombres femeninos árabes (ism 'alam) de Granada (1500) ${ }^{90}$.}

\begin{tabular}{llccc}
\hline & ISM 'ALAM & FRECUENCIA & \% ACUMULADO & CASOS \\
\hline 1 & Fatima [Fāțima] & $32,51 \%$ & 32,51 & 224 \\
2 & Axa ['Āiša] & $31,35 \%$ & 63,86 & 216 \\
3 & Omalfata [Umm al-Fath]] & $14,37 \%$ & 78,23 & 99 \\
4 & Marien [Maryam] & $4,50 \%$ & 82,73 & 31 \\
5 & Omaleoli [Umm al-Wālīd] & $2,76 \%$ & 85,49 & 19 \\
\hline
\end{tabular}

88. Los siguientes 28 nombres aparecen exclusivamente en una sola ocasión (equivalen cada uno al 0,14\% del total de los nombres de varón en la nómina): Abdulazis ['Abd al-'Azīz], Abelud [Abū'l-yumm?], Abrax [Abū ra's?], Ala ['Alā], Almoran [Marwān?], Anbar ['Amr?], Azenez [¿?], Bancaliz [Bahīlīz?], Bati [Badī?], Çuleman [Sulaymān], Fala [¿?], Fuçey [Husayn?], Galid [Walīd], Gedarreya [¿?], Hadan [Haddād?], Halib [Gālib?], Hamerlen [¿?], Hay [Hayy?], Hubey [Hubāb?], Macael [Mīkāyìll], Mochs [¿?], Mulad [Mu'āḍ?], Patra [Badr?], Ximon [Șim'ān], Xuay [Šuhayb?], Yala [Ya'lā], Yayey [Yahyà] y Yeyça [Ya'îšs?].

89. El uso del concepto de hápax (o hapax legomenon) se utiliza en este estudio no en el sentido de identificar un término - en este caso un antropónimo- único y desconocido por la tradición cultural de la que dimana, sino en el sentido más amplio de identificar un término que surge una sola vez dentro del corpus o la muestra que se maneja en un estudio concreto.

90. Los nombres que figuran en el cuadro incluyen las siguientes variaciones en la transliteración del árabe al castellano. Fatima incluye Fatyma. Axa incluye Ahaja, Aixa, Aja, Axe, Haxa, Haxe, Fax y Faxa. Omalfata incluye Omarfata, Omalfaate, Omarfate, Omalfate, Malfate, Malfad y Marfata. Marien incluye Merien y Mary. Omaleoli incluye Omale Oli, Omalaoli, Omaroli, Omalioli, Omali, Omareoli, Omalyoli y Mabanli. Omalhazen incluye Omalfaçen, Omalhasçen, Omalfazen, Omalazen, Omalaçen, Omalaçin Umafaçin, Malhaçen, Malfaze y Malfaçen. Zara incluye Sahara. Xança incluye Xançi, Xançe, Xençi, Xeunçe, Xemeçi y Xemeçia. Çayda incluye Çeyda y Çayde. Bubarica incluye Bobarica y Buvalica. Mahabuva incluye Muhabuva y Mafabuba. Equebil incluye Yquibil. Maçota incluye Maçoda. Omalhany contiene Homalfany y Mafany. Se ha optado en el cuadro por la forma más común reflejada en las nóminas y se ha incluido entre paréntesis la correspondencia árabe más próxima. 


\begin{tabular}{rlccc}
\hline & ISM 'ALAM & FRECUENCIA & $\%$ ACUMULADO & CASOS \\
\hline 6 & Omalhazen [Umm al-Hasan] & $2,18 \%$ & 87,67 & 15 \\
7 & Zara [Zāhira] & $1,60 \%$ & 89,27 & 11 \\
8 & Xança [Šams] & $1,60 \%$ & 90,87 & 11 \\
9 & Camar [Qamar] & $1,45 \%$ & 92,32 & 10 \\
10 & Çayda [Sa'īda] & $0,87 \%$ & 93,19 & 6 \\
11 & Bubarica [Mubārika] & $0,58 \%$ & 93,28 & 4 \\
12 & Equebil [al-Kabīr] & $0,44 \%$ & 93,77 & 3 \\
13 & Mahabuva [Maḥbūba] & $0,44 \%$ & 94,21 & 3 \\
14 & Omalhany [Umm al-hanā?] & $0,44 \%$ & 94,65 & 3 \\
15 & Alia ['Alyà] & $0,29 \%$ & 94,94 & 2 \\
16 & Fahua [Fah̆r?] & $0,29 \%$ & 95,23 & 2 \\
17 & Maçota [Mas'ūda] & $0,29 \%$ & 95,52 & 2 \\
18 & Omarida [Umm Ridà] & $0,29 \%$ & 95,71 & 2 \\
19 & Yamina [Āmina?] & $0,29 \%$ & 96,10 & 2 \\
& Otros ${ }^{91}$ & $3,48 \%$ & 99,58 & 24 \\
\hline & Total & $\mathbf{1 0 0 , 0 0 \%}$ & & 689 \\
\hline
\end{tabular}

Cuadro 3. Ism 'alam masculinos de al-Andalus (siglos $\mathrm{X}-\mathrm{XI})^{92}$.

\begin{tabular}{llccc}
\hline & ISM 'ALAM & FRECUENCIA & \% ACUMULADO & CASOS \\
\hline 1 & Muhammad & $20,85 \%$ & 20,85 & 236 \\
2 & Aḥmad & $13,60 \%$ & 34,45 & 154 \\
3 & 'Abd Allāh & $8,75 \%$ & 43,20 & 99 \\
4 & Sa'īd & $4,95 \%$ & 48,15 & 56 \\
5 & 'Abd al-Raḥmān & $4,33 \%$ & 52,48 & 49 \\
\hline
\end{tabular}

91. Hay 24 nombres que figuran una sola vez (0,15\% cada uno): Acorretalayny [Qurrat al-`ayn], Afia ['Āfiya], Anesuna ['Ayšūna], Auli ['Alla], Bubaran [¿?], Çadaba [¿?], Cuesma [Qusayma?], Fafa [¿?], Fata [Faḍl?], Fatia [Fatyān?], Fay [Fajr?], Foçayn [Fuțayma?], Guebiça [Kabīra?], Hara [Hawr?], Humalez [Umm al-'ayš], Jofar [Ŷ́a'fara?], Muça [Muzna?], Munina [Maymūna?], Omaçat [Umm Sa'd], Xiran [Širīn?], Xofuma [¿?], Zeny [Zaynab?], Zidal [¿?], y Zohor [Zuhayr?].

92. Los datos del cuadro han sido extraídos del listado onomástico efectuado por M.L. ÁvILA, La sociedad hispanomusulmana al final del califato (Aproximación a un estudio demográfico), Madrid, CSIC, 1985, pp. 93-180. Son 1.132 nombres masculinos árabes de la época califal de al-Andalus desde la segunda mitad del siglo X al XI, extraídos de las obras de Ibn al-Faraḍī, Ibn Baškuwāl e 'Iyāḍ. Se han eliminado de la muestra los escasos nombres femeninos que figuran en el elenco. 


\begin{tabular}{|c|c|c|c|c|}
\hline & $I S M{ }^{\prime} A L A M$ & FRECUENCIA & $\%$ ACUMULADO & CASOS \\
\hline 6 & Yahyyà & $3,00 \%$ & 55,48 & 34 \\
\hline 7 & Jalaf & $2,74 \%$ & 58,22 & 31 \\
\hline 8 & Ibrāhīm & $2,56 \%$ & 60,78 & 29 \\
\hline 9 & ‘Alī & $1,68 \%$ & 62,46 & 19 \\
\hline 10 & ‘Umar & $1,59 \%$ & 64,05 & 18 \\
\hline 11 & Sulaymān & $1,50 \%$ & 65,55 & 17 \\
\hline 12 & 'Abd al-Malik & $1,50 \%$ & 67,05 & 17 \\
\hline 13 & Yūsuf & $1,41 \%$ & 68,46 & 16 \\
\hline 14 & Qāsim & $1,41 \%$ & 69,87 & 16 \\
\hline 15 & ‘'̄sà & $1,33 \%$ & 71,20 & 15 \\
\hline 16 & Ismā'îl & $1,24 \%$ & 72,44 & 14 \\
\hline 17 & 'Abd al-'Azīz & $1,24 \%$ & 73,68 & 14 \\
\hline 18 & Așbag & $1,06 \%$ & 74,74 & 12 \\
\hline 19 & 'Utmān & $0,97 \%$ & 75,71 & 11 \\
\hline 20 & Hišām & $0,88 \%$ & 76,59 & 10 \\
\hline 21 & ‘Ubayd & $0,88 \%$ & 77,47 & 10 \\
\hline 22 & Mūsà & $0,71 \%$ & 78,18 & 8 \\
\hline 23 & Husayn & $0,71 \%$ & 78,89 & 8 \\
\hline 24 & Isḥāq & $0,62 \%$ & 79,51 & 7 \\
\hline 25 & Hakam & $0,62 \%$ & 80,13 & 7 \\
\hline 26 & Hasan & $0,62 \%$ & 80,75 & 7 \\
\hline 27 & Marwān & $0,62 \%$ & 81,37 & 7 \\
\hline 28 & Walīd & $0,53 \%$ & 81,90 & 6 \\
\hline 29 & Mas'ūd & $0,44 \%$ & 82,34 & 5 \\
\hline 30 & ‘Abbās & $0,44 \%$ & 82,78 & 5 \\
\hline 31 & Jālid & $0,44 \%$ & 83,22 & 5 \\
\hline \multirow[t]{2}{*}{32} & Zakariyyā' & $0,44 \%$ & 83,66 & 5 \\
\hline & Total & $83,66 \%$ & & 947 \\
\hline
\end{tabular}


Cuadro 4. Nombres masculinos de mudéjares de Toledo (1401-1500) ${ }^{93}$.

\begin{tabular}{|c|c|c|c|c|}
\hline & $I S M{ }^{\prime} A L A M$ & FRECUENCIA & $\%$ ACUMULADO & CASOS \\
\hline 1 & Mahomad [Muhammad], & $20,0 \%$ & 20,0 & 39 \\
\hline 2 & Alí [’Alī] & $15,9 \%$ & 35,9 & 31 \\
\hline 3 & Abrahem [Ibrāhīm] & $15,9 \%$ & 51,8 & 31 \\
\hline 4 & Hamete [Ahmad] & $12,8 \%$ & 64,6 & 25 \\
\hline 5 & Abdalla ['Abd Allāh] & $11,8 \%$ & 76,4 & 23 \\
\hline 6 & Yuçaf [Yūsuf] & $11,8 \%$ & 88,2 & 23 \\
\hline 7 & Yahya [Yahyyà] & $3,6 \%$ & 91,8 & 7 \\
\hline 8 & Ydam $[\bar{A} d a m]$ & $1,5 \%$ & 93,3 & 3 \\
\hline 9 & Çali [Ṣāliḥ] & $1,0 \%$ & 94,3 & 2 \\
\hline 10 & Iça ['Īsà], & $1,0 \%$ & 95,3 & 2 \\
\hline \multicolumn{2}{|r|}{11 Abderramen ['Abd al-Raḥmān] } & $1,0 \%$ & 96,3 & 2 \\
\hline & Otros $^{94}$ & $3,7 \%$ & 100,0 & 7 \\
\hline & Total & $100,0 \%$ & & 195 \\
\hline
\end{tabular}

Resulta desproporcionadamente elevado que el primer nombre de la lista de ism masculino, Mahomad [Muhammad], sea llevado por el 39,31\% de los varones de la nómina. Otras muestras onomásticas mudéjares del siglo XV revelan una incidencia del nombre del profeta de entre el 12\% para Ávila; el 20\% para Toledo; el 28,17\% para Lisboa; y el 33,86\% para Aragón, si bien hay que tener en cuenta que muchas de estas muestras son muy reducidas y no siempre reflejan adecuadamente la población mudéjar. En cuanto a la muestra de la población andalusí de finales del siglo X e inicios del XI la incidencia del ism Muhammad es del 20,85\% $\%^{95}$.

93. Los datos están tomados del cuadro de J.-P. MolÉnAT, «Mudéjars et mozarabes à Tolède du XII au XVe siècle», Revue du Monde Musulman et de la Méditerranée, 63-64, 1-2, 1992, p. 147, para los años que van desde 1401-1425, 1426-1450, 1451-1475 y 1476 a 1500 (las últimas cuatro columnas). Se ha optado por incorporar todo el siglo XV en vez del último cuarto de siglo por la exigüidad de la muestra en cada una de las franjas temporales.

94. Los nombres que figuran una sola vez son, Omar, Lope, Hasis, Abdelasis, Haçan, Farax y Çayde.

95. Para el caso de Ávila el dato está tomado de S. de TAPIA SÁNCHEZ, La comunidad morisca de Ávila, Salamanca, Universidad de Salamanca, 1991, p. 90. La muestra aragonesa viene de C. LALIENA CoRberA, op. cit., pp. 158-159. Ver el cuadro 3 para el dato andalusí, y el cuadro 4 para el caso de los mudéjares toledanos que tampoco sobrepasan el $20 \%$. El caso lisboeta puede resultar algo distorsionado al ser recabado el repertorio del ism también de los padres y abuelos que figuran en el nasab de los individuos en cuestión: ver F. LOPES DE BARROS, «The Identification of Portuguese...», p. 223. 
Si añadimos la frecuencia de Muhammad a la del segundo ism más común en 1500, Hamet [Ahmad] con 16,96\% de la muestra masculina, se constata que más de la mitad de la población (el 56,27\%) lleva estos dos nombres, que además proceden de la misma raíz árabe ḥmd. Estos dos nombres, con alguna excepción, escasamente superan el tercio de la población masculina en las demás nóminas peninsulares de apelativos árabes (ver cuadros 3 y 4$)^{96}$.

En general, se aprecia una alta concentración antroponímica para los varones granadinos en 1500 si se compara con la muestra andalusí y -lo que es más sorprendente- con la mayoría de las muestras mudéjares. Sólo cuatro ism de la nómina de 1500 (Mahomad, Hamet, Ali y Caçin) conforman las tres cuartas partes de la población masculina. Para alcanzar esta tasa es preciso reunir cinco nombres en la muestra mudéjar toledana, seis en la muestra lisboeta, ocho en la avilesa, y hasta 18 ism en la muestra andalusí del cambio de milenio ${ }^{97}$. Es más, la concentración onomástica neta de la nómina masculina es la más alta de todas las nóminas consultadas. Si el elenco masculino de 1500 incluye un nombre por cada 14 individuos, la ratio avilesa es de 1:12, la toledana y la lisboeta es de 1:11 y la andalusí alcanza 1:7. Sólo la muestra aragonesa -con una proporción de un nombre por cada 23 individuos- supera a la ratio de 1500.

Si ya es complicado escrutar el rastro documental de musulmanes varones en documentos medievales cristianos, aún más difuso es el de las mujeres (tanto en las fuentes cristianas como en las musulmanas): de ahí lo valioso de esta nómina de ism de 1500 (cuadro 2), con una muestra de 689 mujeres que representan un gran abanico social. El obstáculo con el que nos encontramos en este caso es la escasez de puntos de comparación ${ }^{98}$.

La concentración antroponímica femenina es algo mayor que en la nómina de varones, un ism por cada 16 mujeres. Asimismo, la variedad de ism femenino es algo inferior al masculino con un total de 43 apelativos personales de los que 19 son recurrentes y 24 constan en una sola ocasión. La concentración

96. Los mudéjares de Ávila son los que muestran menos incidencia de estos dos nombres (21\%): S. de TAPIA SÁNCHEZ, op. cit. La excepción, de nuevo, la encontramos en el cómputo especial del ism de los mudéjares lisboetas con un 41,26\% del total: F. LOPES DE BARROS, «The Identification of Portuguese...». Asimismo, la muestra de Aragón supera ligeramente el tercio con un 36,90\%: C. LALIENA CORBERA, op. cit.

97. El caso aragonés es el único que se aproxima algo a la concentración granadina, aunque no llega a superarla. Los cuatro nombres más frecuentes de la muestra de Aragón alcanzan una tasa del 72,84\%: C. LALIENA CORBERA, op. cit.

98. Los repertorios onomásticos árabes de mujeres mudéjares publicados son limitadísimos y normalmente basados en una muestra insuficiente, por lo que de poco nos sirve utilizarlos como contraste con la nómina de 1500. Por ejemplo, ver el caso de las mujeres mudéjares de Lisboa y Évora en F. LOPES DE BARROS, «The Identification of Portuguese...», p. 225; o el caso de Ávila con una muestra de 36 mujeres en S. de TAPIA SÁNCHEZ, op. cit., p. 80. Para la onomástica femenina andalusí como referente previo ver M. MARíN, «Notas sobre onomástica y denominaciones femeninas en al-Andalus (siglos VIII-XI)», Homenaje al profesor Darío Cabanelas Rodríguez, I, Granada, Universidad de Granada, 1987, pp. 37-52. 
de los dos primeros apelativos personales -Fatima [Fātima] y Axa ['Āiša]están muy igualados y acaparan casi las dos terceras partes de la nómina femenina $(63,86 \%)$. Si contrastamos esta nómina con otra que recopiló Labarta de las moriscas valencianas (muy mediatizada y cronológicamente posterior a la prohibición del ism árabe), nos encontramos con que la concentración onomástica es radical-mente superior a la nómina granadina de 1500, como era de esperar (1:66 com-parado con 1:16). Sin embargo, aunque los dos primeros ism femeninos valen-cianos coinciden con los granadinos, sorprende que su incidencia sea mayor en 1500 que entre las moriscas de Levante, cuya frecuencia conjunta es sólo de 46,11\% (Fāṭima, 23,97\%; y 'Āiša, 22,14\% $)^{99}$.

\section{¿UN CAMBIO DE MENTALIDAD EN LA SOCIEDAD NAZARÍ?}

Cabe preguntarse por qué hubo tal concentración onomástica en las nóminas árabes de 1500, y más concretamente en la nómina masculina. Por un lado, al contrario de lo que cabría esperar, su ratio es mayor que en la nómina andalusí, compuesta esencialmente por sabios e individuos de cierta prominencia social; por otro, más sorprendente aún, supera incluso la ratio de las muestras de mudéjares castellanos y portugueses, cuyas poblaciones ya habían sucumbido a una fuerte aculturación. Este dato puede sugerir un cambio paradigmático en la mentalidad granadina a lo largo del siglo XV.

No sería extraño dado que desde principios del siglo XV hubo un recrudecimiento del acoso militar castellano hacia el emirato de Granada que posiblemente dio lugar a la paulatina concienciación, por parte de la población granadina, de su ineludible extinción política ${ }^{100}$. Si la identidad colectiva nazarí pasaba íntimamente por su adscripción al Islam, no sería descabellado pensar que, debido a la propaganda militar castellana -a menudo infundida de una retórica religiosa de guerra santa y hasta de cruzada al igual que la réplica nazarí elaborada en los mismos términos para contrarrestarla- los granadinos se reafirmaran en ciertas señas de identidad inmanentes de su fe.

Si nos basamos en la clásica -aunque polémica- teoría de Bulliet sobre la relación directa del ism en la afirmación de la adherencia de un colectivo a la religión islámica, hemos de pensar que un cambio antroponímico en el siglo XV constituye una evolución factible dada la sensación de asedio político a la vez que religioso. Basándose en la incidencia de los nombres más vinculados a los primeros protagonistas del Islam (como Muhammad, Aḥmad, 'Alì, al-Hasan y

99. Esta mayor concentración antroponímica femenina de la nómina granadina se repite hasta entre los cinco nombres más comunes (85,49\% acumulado) comparado con el repertorio morisco valenciano (80,33\% acumulado). A partir del sexto nombre la concentración relativa se va igualando y luego se ve superada por la nómina valenciana: A. LABARTA, La onomástica de los moriscos..., p. 61.

100. R. ArIÉ, L'Espagne musulmane au temps des Nasrides (1232-1492), Paris, 1973, pp. 417-420. 
al-Husayn), Bulliet estableció unas curvas de lo que denomina conversión social a la nueva religión de poblaciones sometidas a la expansión islámica ${ }^{101}$. En su estudio de al-Andalus, afirmó que el punto álgido de la curva se alcanzaría entre los años 1200 y 1300 con un 70 a 75\% de la población masculina que adoptaría estos cinco ism, después del cual el porcentaje se mantendría más o menos constante ${ }^{102}$. Pese a las críticas que se puedan esgrimir contra su hipótesis -sobre todo en relación a la muestra onomástica adoptada- el origen de la motivación de esa transformación onomástica se puede considerar válido, aunque no necesariamente tengan que ser exclusivamente estos cinco ism seleccionados los más representativos de ese cambio. De cualquier manera, si hacemos el cómputo de estos cinco ism en la nómina de 1500 resulta que se aproxima, con el 69,33\%, a la cresta que estableció en su gráfico para todo el siglo XIII ${ }^{103}$. Más que indicar tasas de conversión social, en este caso estaríamos ante una reafirmación de las señas de identidad de un colectivo. De nuevo, si establecemos puntos de comparación con otras nóminas mudéjares del siglo XV encontramos que la nómina de granadinos supera una vez más la tasa de todas las demás: Ávila con un 42\%, Toledo con un 49,2\%, Aragón con menos del 55\%, y Lisboa con un 57\% ${ }^{104}$.

Cabe preguntarse si la percepción de acoso religioso entre los mudéjares peninsulares no fue tan pronunciada como aquélla que caló en la mentalidad de los nazaríes. Los mudéjares durante el siglo XV (al menos en el caso castellano y aragonés), más que recibir presiones para renunciar al Islam y convertirse al Cristianismo, fueron sometidos si acaso a medidas de apartamiento cultural -como la prohibición de llevar un nombre cristiano- precisamente para reforzar su diferencia étnico-religiosa porque los cristianos temían que se asimilaran y pudieran confundirse con la mayoría. Dicho de otro modo, no se combatió específicamente contra el Islam en las aljamas de los reinos hispánicos y, por consiguiente, los cristianos no proporcionaron una causa de reacción que robusteciera la identidad musulmana de los mudéjares ${ }^{105}$. No obstante, quizás sería osado suponer que la acendrada aculturación de los mudéjares podría haber empezado a reflejarse en un menor apego al credo islámico como fundamento de su identidad social. Indudablemente se requieren más estudios -y no sólo de índole onomástico- para poder determinar este hipotético extremo.

101. R.W. Bulliet, Conversion to Islam in the Medieval Period. An Essay in Quantitative History, Boston, Harvard University Press, 1979, especialmente los capítulos IV y VI.

102. Para el caso del Islam peninsular, Bulliet argumenta que el último aumento de estos cinco apelativos islámicos se debe a "... a second surge of popularity resulting from the accelerating Christian reconquest of Spain and the strong feeling it aroused that one should openly proclaim one's Muslim identity", ibidem, p. 119.

103. Ibídem, capítulo X, y específicamente el gráfico 21, p. 118.

104. Ver referencias en nota 95.

105. M.A. LADERO QuesAdA, Los mudéjares de Castilla y otros estudios de historia medieval andaluza, Granada, Universidad de Granada, 1989, pp. 80-81. 


\section{EL ANÁLISIS ANTROPONÍMICO DEL NOMBRE CRISTIANO EN 1500}

En lo que respecta a los nombres romances de los granadinos conversos, no hay que perder de vista que son nombres impuestos por cristianos viejos en un acontecimiento multitudinario y que su trascendencia como factor de aculturación es menor que el nombre castellano dado por los propios moriscos en las siguientes generaciones a su prole. No obstante, su importancia radica en que constituye una muestra de referencia a comparar con las nóminas moriscas posteriores (1569), como veremos más adelante; asimismo es el punto de partida de una evolución antroponímica concreta que revela algunas de las motivaciones y la dirección que tomaría la política de conversión forzosa de cientos de miles de musulmanes en el recodo del siglo XV al XVI.

Sólo un nombre, Juan, aglutina a un cuarto de la población masculina de la muestra de 1500 (ver cuadro 5). Un total de cinco nombres son conferidos a más de las tres cuartas partes de la población masculina (además de Juan, están Françisco, Alonso, Fernando y Pedro). Si contrastamos este repertorio con los nombres de viejo-cristianos para el último cuarto del siglo $\mathrm{XV}$, constatamos que diez nombres ocupan casi el 69\% en el caso de Sevilla (ver cuadro 7), cifra considerablemente mayor que en la nómina de 1500, donde sólo cuatro nombres aglutinan ese mismo porcentaje. En otra nómina de cristianos viejos de Córdoba del siglo XV, esa diferencia disminuye ligeramente -son seis los nombres que ocupan más de dos tercios de la población- pero el stock es notablemente mayor: 55 nombres para Córdoba comparado con 32 nombres para los granadinos, a pesar de contar ésta con una muestra mayor ${ }^{106}$.

Cuadro 5. Nombres castellanos de moriscos de Granada (1500).

\begin{tabular}{llrcc}
\hline & NOMBRE & FRECUENCIA & $\%$ ACUMULADO & CASOS \\
\hline 1 & Juan & $25,10 \%$ & 25,10 & 196 \\
2 & Françisco & $16,52 \%$ & 41,62 & 129 \\
3 & Alonso & $16,26 \%$ & 57,88 & 127 \\
4 & Fernando & $10,88 \%$ & 68,76 & 85 \\
5 & Pedro & $6,27 \%$ & 75,03 & 49 \\
6 & Gonçalo & $4,74 \%$ & 79,77 & 37 \\
7 & Diego & $4,23 \%$ & 84,00 & 33 \\
8 & Martyn & $3,59 \%$ & 87,59 & 28 \\
\hline
\end{tabular}

106. M.C. Aguilera CASTRO, «Los nombres de los cordobeses en la segunda mitad del siglo XV», en La Vida Cotidiana en la España Medieval. Actas del VI Curso de Cultura Medieval, Madrid, 1998, pp. 247-257. 


\begin{tabular}{rlrcc}
\hline & NOMBRE & FRECUENCIA & \% ACUMULADO & CASOS \\
\hline 9 & Anton & $1,79 \%$ & 89,38 & 14 \\
10 & Cristoval & $1,79 \%$ & 91,17 & 14 \\
11 & Rodrigo & $1,66 \%$ & 92,83 & 13 \\
12 & Bartolome & $1,28 \%$ & 94,11 & 10 \\
13 & Luys & $1,02 \%$ & 95,13 & 8 \\
14 & Andres & $0,90 \%$ & 96,03 & 7 \\
& Otros ${ }^{107}$ & $3,97 \%$ & 100,0 & 31 \\
\hline & Total & $\mathbf{1 0 0 , 0} \%$ & & 801 \\
\hline
\end{tabular}

Cuadro 6. Nombres castellanos de moriscas de Granada (1500).

\begin{tabular}{rlrcr}
\hline & NOMBRE & FRECUENCIA & $\%$ ACUMULADO & CASOS \\
\hline 1 & Leonor & $29,86 \%$ & 29,86 & 206 \\
2 & Marya & $22,17 \%$ & 52,03 & 153 \\
3 & Catalina & $18,26 \%$ & 70,29 & 126 \\
4 & Ysabel & $15,94 \%$ & 86,23 & 110 \\
5 & Juana & $3,77 \%$ & 90,00 & 26 \\
6 & Françisca & $3,04 \%$ & 93,04 & 21 \\
7 & Elvyra & $2,46 \%$ & 95,50 & 17 \\
8 & Beatris & $0,87 \%$ & 96,37 & 6 \\
9 & Ana & $0,72 \%$ & 97,09 & 5 \\
10 & Ynes & $0,58 \%$ & 97,67 & 4 \\
11 & Marina & $0,43 \%$ & 98,10 & 3 \\
12 & Mençia & $0,43 \%$ & 98,53 & 3 \\
13 & Aldonça & $0,29 \%$ & 98,82 & 2 \\
14 & Elena & $0,29 \%$ & 99,11 & 2 \\
& Otros ${ }^{108}$ & $0,84 \%$ & 99,95 & 6 \\
\hline & Total & $99,95 \%$ & & 690 \\
\hline
\end{tabular}

107. Seis son los nombres que figuran tres veces cada uno (0,38\%): Adan, Álvaro, García, Gaspar, Myguel y Sancho. Sólo un nombre, Geronymo, figura dos veces $(0,26 \%)$. Asimismo, contamos con otros 11 nombres cristianos que se conceden en una sola ocasión (equivale al 0,13\% del total de nombres varones): Benyto, Bernardino, Carlos, Domingo, Jorje, Lope, Lorenzo, Marcos, Nuño, Sebastian e Yñigo.

108. Figuran otros seis nombres con una sola mención (equivalente al 0,14\%): Antonia, Barbara, Biolante, Giomar, Luzia y Ursula. 
Esa elevada concentración se acentúa aún más entre los nombres de pila de las mujeres granadinas. Sólo los dos primeros nombres, Leonor y María, acaparan más de la mitad de la población de la muestra, mientras que para alcanzar ese mismo porcentaje entre los cristianos viejos se precisan cuatro nombres en el caso sevillano y cinco para la muestra de Córdoba. La ratio de concentración antroponímica es de un nombre por cada diez mujeres de la muestra cordobesa, mientras que alcanza un nombre por cada 34 mujeres entre los nombres otorgados durante la conversión de Granada.

Es indudable que las modas onomásticas de la población cristiana fueron consciente o inconscientemente reproducidas por los que oficiaron el bautismo de esta primera generación de moriscos granadinos. El caso más singular es el de los nombres más frecuentes de las mujeres que reflejan -como ya remarcó Ladero Quesada- el de la familia real, incluyendo la reina Isabel y las infantas Juana, Catalina, Isabel y María ${ }^{109}$.

Si bien el orden de los nombres proporcionados a los granadinos y a las granadinas no coinciden exactamente con la onomástica cristiana tradicional de finales del siglo XV, tienden a ser los habituales si hacemos caso omiso de ciertos hapax anecdóticos. La reducción onomástica probablemente responde al factor repetitivo causado por el hecho de que uno o pocos individuos fueran responsables de adjudicar un nombre para cada neófito que asistiera al bautismo a lo largo de uno o varios días. Pese a contar con otros responsables del bautismo, la conversión en la parroquia granadina de San Gregorio estudiada por Ladero Quesada muestra un acervo y frecuencias relativamente similares a las que se han calculado en nuestra nómina de las parroquias de Santa Isabel y San Salvador, por lo que el proceso de cambio antroponímico parece haber sido constante en la ciudad de Granada a inicios de $1500^{110}$. Asimismo, no hay constancia de una tasa desproporcionada del nombre del propio padrino (en las escasas ocasiones que se conoce) en las distintas parroquias de la nómina, como sin embargo insisten algunos investigadores para otros procesos de conversión ${ }^{111}$.

109. M.A. LAdero QueSADA, «Los bautismos de los musulmanes...», p. 504. Aunque el nombre más común entre las moriscas -el de Leonor- no se encuentre entre las hijas de los Reyes Católicos, no hay que perder de vista que fue un nombre muy habitual entre la realeza hispánica durante gran parte de la Edad Media, y en 1498 nacería la primogénita de la infanta Juana y el Archiduque de Austria, Felipe, y recibiría precisamente el nombre de Leonor.

110. Ibídem, pp. 502-503.

111. B. VINCENT, «El nombre cristiano de los moriscos», en Minorías y marginados en la España del siglo XVI, Granada, Diputación provincial de Granada, 1987, pp. 39-40; M. ROMERO SÁIZ, Mudéjares y moriscos en Castilla-La Mancha. Aproximación a su estudio, Cuenca, Editorial Llanura, 2007, pp. 136137. El caso más claro donde el nombre de uno de los testigos del bautismo influye decisivamente en la selección antroponímica y distorsiona los porcentajes con respecto a otras nóminas es la de la diócesis de Guadix en 1501. El nombre de Luys (poco frecuente entre los castellanos) es el más común entre los conversos, y Luysa (aún más raro) es el segundo en proporción entre las conversas. No es de extrañar que uno de los tres testigos se llame Luis Biamonte: ver C.J. GARRIDO GARCÍA, «El establecimiento de la estructura eclesiástica en el Reino de Granada como condicionante de las conversiones mudéjares. El caso de la Diócesis de Guadix», Actas del VIII Simposio Internacional de Mudejarismo, vol. I, Teruel, Centro de Estudios Mudéjares, 2002, pp. 596 y 600-604. 


\section{Cuadro 7. Nombres masculinos y femeninos de Sevilla (1475-1499) ${ }^{112}$.}

\begin{tabular}{|c|c|c|c|c|c|c|c|}
\hline C-7a & $\begin{array}{l}\text { NOMBRE } \\
\text { MASCULINO }\end{array}$ & FRECUENCIA & $\%$ ACUMULADO & $C-7 b$ & $\begin{array}{l}\text { NOMBRE } \\
\text { FEMENINO }\end{array}$ & FRECUENCIA & $\%$ ACUMULADO \\
\hline 1 & Juan & $16,2 \%$ & 16,2 & 1 & María & $18,2 \%$ & 18,2 \\
\hline 2 & Pedro & $15,3 \%$ & 31,5 & 2 & Leonor & $13,9 \%$ & 31,2 \\
\hline 3 & Alfonso & $9,9 \%$ & 41,4 & 3 & Isabel & $10,7 \%$ & 41,9 \\
\hline 4 & Fernando & $8,4 \%$ & 49,8 & 4 & Beatriz & $8,6 \%$ & 50,5 \\
\hline 5 & Diego & $8,1 \%$ & 57,9 & 5 & Juana & $8,6 \%$ & 59,1 \\
\hline 6 & Francisco & $4,5 \%$ & 62,4 & 6 & Catalina & $7,5 \%$ & 66,6 \\
\hline 7 & Rodrigo & $2,3 \%$ & 64,7 & 7 & Inés & $6,4 \%$ & 73,0 \\
\hline 8 & Enrique & $2,3 \%$ & 67,0 & 8 & Constanza & $4,3 \%$ & 77,3 \\
\hline 9 & Gonzalo & $1,8 \%$ & 68,8 & 9 & Teresa & $3,2 \%$ & 80,5 \\
\hline 10 & García & $1,0 \%$ & 69,8 & & Otros & $18,6 \%$ & 99,1 \\
\hline 11 & Alvar & $1,0 \%$ & 70,8 & & & & \\
\hline 12 & Martín & $0,6 \%$ & 71,4 & & & & \\
\hline \multirow{3}{*}{13} & Sancho & $0,6 \%$ & 72,0 & & & & \\
\hline & Otros $^{113}$ & $28 \%$ & 100,0 & & & & \\
\hline & Total & $100,0 \%$ & & & Total & $99,10 \%$ & \\
\hline
\end{tabular}

A pesar de un relativo alto grado de homonimia entre los conversos, no parece que mediara un intento de etiquetar a los nuevos conversos con un marcador onomástico. Igualmente, puede descartarse una lógica consciente en la adjudicación de nombres cristianos vinculados de alguna manera al ism árabe. Sin embargo, a partir de cruces estadísticos entre el ism y el nombre de pila, se ha podido determinar que ciertos apelativos personales árabes inducen a los sacerdotes o escribanos a asignar preferentemente ciertos nombres sobre otros, aunque probablemente de forma inconsciente ${ }^{114}$. Ocurre algo similar con

112. Los datos del cuadro han sido extraídos de F. GARCíA FITZ y J.M. MiURA ANDrADES, «Los anales de don Diego Ortiz de Zúñiga. Un análisis de la onomástica medieval sevillana», Actas del II Congreso de Historia de Andalucía, Historia Medieval, Córdoba, 1994, p. 194. Se han utilizado los datos de la columna 10 del cuadro I-1, correspondientes a los nombres masculinos sevillanos de 1475 a 1500 y se han reordenado de mayor a menor frecuencia.

113. Desgraciadamente los datos sobre los nombres y las frecuencias del elenco antroponímico restante no han sido divulgados en la publicación de García Fitz y Miura Andrades.

114. Un individuo con el ism de Çayda tiene un 50\% de posibilidades de que le otorguen el nombre de Catalina, mientras que en la nómina general este nombre de pila apenas supera el $18 \%$. Asimismo, un individuo con el ism de Yça tiene un $60 \%$ de probabilidades de que le bauticen con el nombre de Juan cuando éste apenas supera el 25\% en la nómina. No obstante, debido a la exigua frecuencia de estos ism, las discrepancias se pueden achacar al azar. 
la elección del nombre por parte del oficial cristiano en función de la edad del granadino, aunque de nuevo no parece formar parte de un plan premeditado, sino del poder sugestivo personal del oficial que media en dicha elección ${ }^{115}$.

Hasta cierto punto, parece que sí rechazaron la trasnominación, es decir, pasar de un ism árabe a su equivalente castellano, a pesar de ser teológicamente lícito. Por ejemplo, nombres como Ibrāhīm, Yūsuf, Yahyà y Maryam tenían sus equivalentes castellanos en Abrahán, José, Juan o María respectivamente. Las autoridades eclesiásticas probablemente eran conscientes de la importancia que escondía el nombre como poderoso receptor de identidad. En este caso, puede verse la expresa voluntad por romper todo vínculo entre el antiguo nombre y el nuevo, o de borrar toda conciencia religiosa y evitar la metonimia, es decir, impedir que el nuevo nombre evocara de alguna forma el original arraigado en la tradición islámica ${ }^{116}$.

Más adelante, abordaremos el análisis de los sobrenombres castellanos y árabes de la nómina de 1500 y los compararemos con las nóminas de 1569 para poder aprehender la evolución onomástica y avanzar alguna hipótesis sobre la autenticidad del uso onomástico árabe según se reconoce y transmite en la documentación cristiana.

\section{EL PROBLEMA DE LA FIJACIÓN DEL NOMBRE CRISTIANO}

El nombre que se le otorga al neófito, al no parecer fijado -es decir, asumido como la identidad onomástica del individuo en cuestión- desde el origen, y al estar en competición con el ism islámico, puede verse alterado con respecto a la forma asignada inicialmente. El morisco que participaba del doble sistema de apelativo, como se conoce por los testimonios inquisitoriales, en ciertas ocasiones no se acordaba de su nombre o el de sus familiares. Vincent ha rastreado los procesos de Valencia y ha encontrado decenas de casos en los que el nombre cristiano ha caído totalmente en el olvido ${ }^{117}$. No hay que descartar que

115. Los individuos que llevan el nombre de Juan tienen una media de 36 años, mientras que los que portan el nombre de Fernando tienen una media de sólo 18 años. Asimismo, para la onomástica femenina, los individuos que adquieren el nombre de Juana tienen una media de 69 años, y sin embargo a los que se les impone el nombre de Catalina no superan los 24 años.

116. Vincent ya se inclinó originalmente por esta hipótesis: “...obtengo la impresión, a confirmar o no, de que el nombre cristiano impuesto a los moriscos está desligado casi por completo de la fe musulmana y de la herencia familiar". B. VINCENT, «El nombre cristiano...», p. 41. No obstante, en el contexto de la conversión de los mudéjares de Castilla, Molénat sí considera que pudo existir cierta metonimia al menos entre aquellos individuos que pudieron elegir su propio nombre. La evocación antroponímica en el ejemplo que presenta de los conversos de Ávila no hace referencia al nombre original del individuo que recibe el bautismo, sino más bien a un nombre que evoca otro nombre musulmán como es el caso de Lope/Lubb (aunque a nuestro modo de ver no deja de ser un caso aislado que pudiera explicarse por otros factores): J.-P MOLÉNAT, «À propos des noms...», pp. 548-549.

117. B. VINCENT, «El nombre cristiano...», pp. 41-43. 
en otros casos en que proporcionan un nombre cristiano, en realidad se estén inventando uno nuevo en caso de fallarle la memoria para evitar delatarse ante las instancias inquisitoriales ${ }^{118}$. La transformación antroponímica de los moriscos a lo largo del siglo XVI debe tener este factor en cuenta, especialmente, como veremos más abajo, en el caso específico de las mujeres moriscas.

El sistema onomástico dual practicado por los mozárabes y en algunos casos por mudéjares, como hemos visto, tiene solvencia cuando existe la voluntad no coercitiva de su uso. Por el contrario, en el caso morisco, el nombre cristiano era considerado, al menos por los cripto-musulmanes, como una imposición ajena a su cultura y a pesar de la amenaza de la Inquisición, no parece haberle preocupado a un importante número mantener la máscara onomástica conservando su apelativo cristiano sólo en la memoria.

Hasta para los viejos cristianos el nombre otorgado durante el bautismo no es más que un nombre teórico en muchos casos, susceptible de múltiples transformaciones en el uso cotidiano y difícilmente reparable en la documentación oficial como advirtió Klapisch-Zuber en el caso de los nombres de la Toscana durante los siglos XIV y XV ${ }^{119}$.

Por otra parte, la teoría de Sublet sobre el velo del nombre árabe hace hincapié en la tendencia que existe entre los musulmanes de llevar apelativos personales alternativos al ism, precisamente para protegerlo. No había que pronunciar este ism por temor a desgastarlo; de ahí que se fomentara el uso de otros elementos onomásticos como la kunya, el laqab, o incluso otros ism. Quizás, con el paso del tiempo, los moriscos no consideraron tan perjudicial un cambio antroponímico que impidiera al cristiano viejo desgastar el ism auténtico y clan-destino del converso. Aunque sea algo meramente especulativo, no es imposible que el nombre cristiano fuera asumido eventualmente como un tipo de velo del nombre árabe utilizado en público ${ }^{120}$.

\section{LAS FADAS Y EL RITO DE LA DESCRISTIANIZACIÓN}

La imposición del nombre en el mundo musulmán viene acompañada de un rito que, pese a no figurar en el Corán, sí forma parte de la Sunna y se cla-

118. Ciertos casos muestran duda al pedirles durante el proceso su nombre cristiano: “Catalina Payot... declara que su hija se llama Futey y de cristiana no sabe el nombre y luego dixo que se llama Esperança...", ibidem, p. 41.

119. C. Klapisch-Zuber, «Quel Moyen Âge pour le nom?», en M. Bourin, J.-M. Martin y F. Menant, L'anthroponymie..., pp. 475-476.

120. "C'est pour préparer l'enfant au moment où il sortira du milieu familial que les parents ont le souci de lui donner des noms qui serviront de <substituts $>$ au 'ism', en particulier 'kunya' et, pour les garçons des surnoms à résonance religieuse composé avec al-dîn, et pour les filles parfois un surnom composé avec sitt (<dame $>$ ) ou des noms de substitution, c'est-à-dire plusieurs sortes de 'ism'", J. SuBLET, Le voile du nom, pp. 191-192. 
sifica teóricamente como un acto religioso ${ }^{121}$. Esto venía a ser conocido por los moriscos como las fadas ${ }^{122}$, basadas en una serie de rituales que incluían no sólo la elección del nombre del neonato, sino también su consagración a Dios como en el caso del bautismo cristiano ${ }^{123}$. De hecho, los moriscos cripto-musulmanes reconocían que el ritual de las fadas era preceptivo según la tradición y que existía un paralelismo con el bautismo cristiano, tal como nos relata el Mancebo de Arévalo en sus enseñanzas aljamiadas ${ }^{124}$. No obstante, Bulliet asevera que en el mundo musulmán no hubo un rito de adopción del credo con la importancia y solemnidad del bautismo cristiano. Un individuo se convierte al Islam pronunciando las ocho palabras de la profesión de fe -la šahāda- sin necesidad de la presencia específica de una autoridad espiritual ${ }^{125}$.

Lo que los mudéjares y moriscos llamaban fadas era aquello que se conocía desde época pre-islámica como tasmiyat al mawlūd, la imposición del nombre al neonato seguido de la profesión de la fe en tiempos islámicos, que se dividía originariamente en dos ceremonias: el tahnīk, en que se frotaba un dátil en el paladar del neonato -práctica que, con el tiempo, cayó en desuso en el mundo islámico- y la 'aqiqqa, donde se cortaba un mechón de pelo del bebé y se donaba su peso en plata u oro, se sacrificaba un animal y se celebraba un banquete ${ }^{126}$.

En la Castilla medieval las autoridades de las aljamas islámicas hicieron hincapié en la importancia de no perder estas tradiciones, que fueron romanceadas al menos desde el siglo XV debido al escaso conocimiento de árabe por parte de los mudéjares asentados en tierras castellanas. Esto es lo que difunde el preeminente alfaquí de Segovia, Iça de Gebir, que entre otras cuestiones sobre el Islam nos habla de la importancia de imponer el nombre musulmán al

121. Aunque el rito como tal no figura en el Corán, sí encontramos referencias atribuidas al profeta Mahoma en el hadit sobre la necesidad de otorgar el ism y él mismo se ocupó de elegir los ism de los recién nacidos y de los conversos al Islam; ver J. SUBLET, Le voile du nom, p. 23. Asimismo, se atribuye también al profeta la siguiente frase: “El día del Juicio Final se os llamará por vuestros nombres y por los nombres de vuestros padres - por lo tanto elijan nombres bellos y llenos de gracia-", traducción española de la cita publicada en A. SCHIMMEL, op. cit., p. 14.

122. Para la etimología del término fadas, Bramón argumenta que proviene del latín fatum, antes que del árabe hadîya, regalo: D. BRAMÓN, «El rito de las fadas, pervivencia de la ceremonia pre-islámica de la 'Aqiqa», en A. TEMIMI (ed.), Las prácticas musulmanas de los moriscos andaluces (1492-1609), Zaghouan, Centre d’Études et de Recherches Ottomanes, Morisques, de Documentation et d'Information, 1989, p. 37.

123. P. LongÁs, La vida religiosa de los moriscos (facsímil de la edición de 1915), Granada, Archivum, 1990, pp. 256-261.

124. "Loš kirištiyanoš kedaron kon-el batišmo i la bendissiyyón rrélika. I loš mmusliymeš dan laš buwenaš fadaš keš la beštiduwra alrrahmoša y-ěs akto de peresebto ssūnal...", Mancebo de Arévalo, Tratado [Tafsira], edición y estudio de M.T. Narváez Córdova, Madrid, Editorial Trotta, 2003, p. 153.

125. R.W. Bulliet, op. cit., p. 33.

126. L. CAetani y G. Gabrieli, op. cit., pp. 62-65; y F. PAReja, Islamología, 2 vols., Madrid, Razón y Fe, 1952-1954, p. 547. 
recién nacido al octavo día después del parto: “...es la orden de como se han de fazer las fadas de las criaturas y el meter el nombre al nascido y á quien se hará muzlim ó á quien no le an metido nombre" ${ }^{\prime 27}$.

A pesar de que a menudo las indicaciones sobre la tasmiya iban seguidas de la obligación de la circuncisión masculina, y a pesar de que a veces llegaban a fundirse en un mismo precepto ${ }^{128}$, estas dos ceremonias eran independientes $^{129}$. Bien es cierto que en la época morisca se siguió celebrando la tasmiya pues algunos testimonios han llegado hasta nosotros; sin embargo, ya no se efectuaba en la mezquita como era tradición, sino en el seno de las casas moriscas. El ritual se adaptó ligeramente para contrarrestar el bautismo cristiano previo, por el que la mayoría de neonatos tuvieron que pasar. A la tasmiya se le añadió un ritual para purificar al niño limpiando la crisma ungida con el fin de contrarrestar el aura del agua bendita impuesta por el sacerdote cristiano, antes de llevar a cabo la ceremonia islámica propiamente dicha.

En su estudio sobre los procesos de la Inquisición de Cuenca contra los moriscos, García-Arenal llega a constatar que las fadas se convierten en un acto cuyo propósito principal es deshacer los efectos del bautismo además de elegir el nuevo nombre islámico del neófito ${ }^{130}$. Asimismo, Caro Baroja ya había avanzado en su estudio clásico sobre los moriscos granadinos que, después del bautismo, al niño le hacían pasar por un "rito moruno" para "descristianizarle"131. Contamos igualmente con la concepción escorada -pero no por ello menos reveladora- que tenían

127. “...Tomarás al nascido á tu mano, la izquierda i tú de cara del alquibla y dezirle es el pergüeno en el oido derecho y el alicama en el isquierdo y despues tomale alguaddo y ataharalo y metanle rropas linpias y pregunten que nonbre a de tener y dezirle an el pregüeno otra vez en el oido derecho y á cada palabra responderán los que estarán presentes con el nonbre del nascido ó nascida. Despues dezirle an el alicama en su oido el esquierdo y por lo mesmo responderán los que estan presentes con el nonbre de la criatura; y despues leerán sobre la cabesa de la criatura el hizbe de Yas una vez y inna inzilnahu..." en Iça de Gebir, «Suma de los principales mandamientos y devedamientos de la ley y çunna», en P. de GAYANGos (ed.), Memorial Histórico Español. Colección de documentos, opúsculos y antigüedades, Tomo V, Madrid, RAH, 1853, p. 331.

128. Ibídem, pp. 331-332: Iça de Gebir titula el capítulo XXXIV, «De las fadas buenas y çircunsiçiones». También es el caso de la visión cristiana vieja del siglo XVI, de la que contamos con el testimonio de Mármol Carvajal en el que asocia el otorgamiento del nombre con la circuncisión: "Cuando habian baptizado algunas criaturas, las lavaban secretamente con agua caliente para quitarles la crisma y el olio santo, y hacian sus cerimonias de retajarlas y les ponían nombres de moros...". Ver L. del Mármol CARVAJAL, Historia del rebelión y castigo de los moriscos del reino de Granada, 1600 (ed. facsimil de 1991), p. 60.

129. Longás constata que los procesos inquisitoriales mencionan que la circuncisión que tradicionalmente se efectuaba al bebé a los ocho días, es decir al tiempo de las fadas, se pospuso hasta los ocho años: ver P. LONGÁs, op. cit., pp. 262-63.

130. M. García-AREnAL, Inquisición y moriscos. Los procesos del tribunal de Cuenca, Madrid, Siglo XXI, 1978, p. 57.

131. J. CARo Baroja, Los moriscos del reino de Granada, Madrid, Alianza Editorial, 2003 (obra publicada originalmente en 1957), p. 113. 
los cristianos viejos contemporáneos sobre estas actividades clandestinas y coinciden en acusar a los moriscos de desbautizar a los neófitos ${ }^{132}$.

Parece ser que un número considerable de moriscos concibieron las fadas, no tanto como una ceremonia de afirmación de la fe islámica sino de neutralización del credo cristiano. Para mostrar el pensamiento religioso comparativo de los moriscos, Epalza saca a colación unos textos pedagógicos de dos criptomusulmanes, Ibrahim Taybili y Ahmad al-Hanafi, exiliados en Túnez. Estos autores esgrimen unos paralelismos contrastando una práctica cristiana con su correspondiente islámico, dejando así relucir las divergencias entre las dos religiones (con la norma islámica triunfando airosamente). De ellas, la dicotomía que queremos destacar aquí es la oposición que establecen entre el bautismo cristiano por una parte y la circuncisión por otra, en vez de la tasmiya como uno esperaría ${ }^{133}$.

Estos reveladores contrastes refuerzan la hipótesis de que las fadas se concibieron más como un acto de reacción contra la religión impuesta que como una afirmación propiamente dicha de la identidad musulmana en todos sus aspectos. Es plausible que el rito que rodea el otorgamiento del nombre musulmán adoptara un sesgo consciente de contraataque al impuro rito del infiel. Difícilmente sabremos hasta qué punto era compartida esta visión por la mayoría de los moriscos granadinos. No obstante, el elevado número de referencias documentales sugiere una amplia difusión de esta actitud y podría ser determinante para entender cómo asumieron los moriscos la onomástica cristiana en el seno de su comunidad.

\section{EL DIMORFISMO SEXUAL EN LA ONOMÁSTICA MORISCA DE 1569}

En líneas generales, no hay duda de que el acervo onomástico masculino castellano tiende a ser más extenso que el femenino tanto para el mundo bajomedieval como para el moderno (algo parecido se puede deducir de la onomástica árabe) ${ }^{134}$. Asimismo, si comparamos la evolución de las listas moriscas de 1500 para ambos sexos con las de 1569 en Granada cabe esperar un in-

132. Un buen ejemplo lo encontramos en la obra de teatro clásico, Los moriscos de Hornachos, donde varios personajes usan el término desbautizar para referirse a las fadas: ver J. FERNÁNDEZ NIEVA, «La comedia Los moriscos de Hornachos. Contenidos ideológico-rituales», en A. TEMIMI (ed.), op. cit., p. 84.

133. M. de EPAlZA, «Rites musulmans opposés aux rites chrétiens dans deux textes de morisques tunisiens: Ibrahim Taybili et Ahmad al-Hanafi», en A. TEMIMI (ed.), op. cit., p. 73. Esta dicotomía también fue remarcada previamente por L. CARDAILLAC, Morisques et chrétiens. Un affrontement polémique (1492-1640), Paris, Klincksieck, 1977, pp. 314-315.

134. Ver los diversos repertorios recogidos en este estudio. 
cremento palpable de la variedad antroponímica para los nombres moriscos de ambos sexos, manteniendo ese diferencial entre el stock de nombres masculinos y femeninos. Recordemos que los nombres de los primeros moriscos granadinos en 1500 fueron impuestos por los artífices del bautismo masivo con una contribución meramente anecdótica por parte de algunos afectados. Después de casi siete décadas viviendo como cristianos -aunque fuera para muchos sólo de forma nominal- sería lógico que el paso de las generaciones acercara el elenco onomástico de los cristianos nuevos al de los cristianos viejos.

Si contrastamos los cuadros de los nombres castellanos, masculinos y femeninos, de la nómina de 1500 (cuadros 5 y 6) con el de los nombres castellanos de ambos sexos de 1569 (cuadros 8 y 9) salta a la vista un fenómeno inesperado. Mientras que entre las mujeres apenas se incrementa el acervo onomástico de 1500 a 1569 (aumenta de 20 a 22 nombres, o un 10\%), entre los hombres el elenco de los nombres se dispara con un aumento que casi alcanza un $50 \%$ (de 32 a 47 nombres). En lo que respecta a la evolución comparativa entre sexos de las concentraciones onomásticas, la diferencia -sin ser tan pronunciada- es palpable también entre hombres y mujeres ${ }^{135}$. Es más, si nos fijamos en los dos nombres más utilizados entre mujeres de los dos sondeos diacrónicos, la tendencia es la inversa a la esperada después de más de dos generaciones utilizando un sistema onomástico castellano: la concentración es aún mayor entre las moriscas de 1569 que el de los nombres otorgados a las islamo-conversas por los sacerdotes del bautismo masivo de inicio de siglo ${ }^{136}$.

Antes de avanzar ciertas hipótesis que justifiquen estos patrones imprevistos, pasemos a una comparación sincrónica para ver qué ocurre con la población viejo-cristiana a partir del último tercio del siglo XVI. Al contabilizar los nombres de los cristianos viejos que habitaban la ciudad de Granada podemos aproximarla a una población con la que los moriscos convivían y de donde se supone llegaron las influencias culturales cristiano-castellanas más inmediatas. Aunque considerable, desgraciadamente, sólo contamos con una muestra de nombres masculinos.

Lo que se antoja inesperado no es que los moriscos varones de Granada estén a punto de alcanzar una variedad onomástica similar a la de sus congéneres viejo-cristianos ${ }^{137}$. El hecho de contar con una apreciable diversidad ono-

135. En 1500, el 90\% de las mujeres llevaban sólo cinco nombres y en 1569 se alcanza esa tasa con nueve nombres. Sin embargo, el $90 \%$ de los varones saltan de nueve apelativos en 1500 a 22 nombres 69 años más tarde (ver cuadros 1, 2, 5 y 6).

136. En 1500 , Leonor $(29,86 \%)$ y María $(22,17 \%)$ son los nombres que se les otorga al $52,03 \%$ de las mujeres durante el bautizo masivo, mientras que en 1569 los dos nombres castellanos más utilizados por las mujeres son María $(31,50 \%)$ e Isabel $(27,11 \%)$, que alcanzan un asombroso $58,61 \%$ en las moriscas.

137. En la década de 1560 hay un nombre por cada 11 viejo-cristianos, mientras que se reseña un nombre por cada 11,6 moriscos en Granada. 
Cuadro 8. Nombres de moriscos del Albayzín (1569) ${ }^{138}$.

\begin{tabular}{rlrrr}
\hline & NOMBRE & FRECUENCIA & \% ACUMULADO & CASOS \\
\hline 1 & Alonso & $15,88 \%$ & 15,88 & 87 \\
2 & Lorenzo & $12,77 \%$ & 28,65 & 70 \\
3 & Diego & $7,12 \%$ & 35,77 & 39 \\
4 & Luis & $6,75 \%$ & 42,52 & 37 \\
5 & Miguel & $6,39 \%$ & 48,91 & 35 \\
6 & Francisco & $6,20 \%$ & 55,11 & 34 \\
7 & Juan & $5,84 \%$ & 60,95 & 32 \\
8 & Fernando & $4,20 \%$ & 65,15 & 23 \\
9 & García & $4,01 \%$ & 69,16 & 22 \\
10 & Andrés & $3,10 \%$ & 72,26 & 17 \\
11 & Sebastián & $2,55 \%$ & 74,81 & 14 \\
12 & Alvaro & $2,01 \%$ & 78,82 & 11 \\
13 & Xristobal & $2,01 \%$ & 80,56 & 11 \\
14 & Antonio & $1,82 \%$ & 82,29 & 10 \\
15 & Bartolomé & $1,64 \%$ & 83,93 & 9 \\
16 & Martín & $1,64 \%$ & 85,57 & 9 \\
17 & Melchior & $1,64 \%$ & 87,03 & 9 \\
18 & Bernardo & $1,46 \%$ & 88,12 & 8 \\
19 & Domingo & $1,09 \%$ & 89,03 & 6 \\
20 & Agustín & $0,91 \%$ & 89,94 & 5 \\
21 & Baltasar & $0,91 \%$ & 90,85 & 5 \\
22 & Bernabé & $0,91 \%$ & 91,76 & 5 \\
23 & Lope & $0,91 \%$ & & 5 \\
24 & Zacarías & $0,91 \%$ & & 5 \\
& Otros ${ }^{139}$ & $7,33 \%$ & & 5 \\
\hline & Total & $100,00 \%$ & & 5 \\
\hline & & & & 5 \\
\hline
\end{tabular}

138. El cómputo onomástico se ha efectuado a partir de las nóminas del Legajo L-6-57 del Archivo de la Alhambra, titulado "Visita a todas las casas del Albaicín para registro de armas" y fechado en 1569; transcrito por J. MARTínEZ RUIZ, «Visita a todas las casas del Albaicín en el año 1569 (Antroponimia, etnología y lingüística)», Cuadernos de la Alhambra, 15-17, 1979-1981, pp. 255-298; 18, 1982, pp. 239-273; 19-20, 1983-1984, pp. 247-283; 22, 1986, pp. 101-135. Se han elegido los nombres de las nóminas de dos parroquias granadinas donde la población era casi exclusivamente (por no decir totalmente) morisca en esta fecha previa a su expulsión y que constituían una muestra numérica suficiente para el análisis antroponímico masculino: San Gregorio y San Nicolás.

139. Hay dos nombres que ocurren cuatro veces $(0,73 \%)$ cada uno: Benito y Gonzalo; dos nombres, Felipe y Gaspar, con tres casos (0,55\%); siete nombres con dos casos (0,36): Gómez, Iñigo, Jerónimo, Jorge, Lucas, Marcos y Pedro; y 12 casos singulares (0,18\%): Ambrosio, Clemente, Damien, Ginés, Graviel, Gregorio, Nicolás, Pablo, Rafael, Rodrigo, Salvador y Tomás. 
mástica no es garantía de que estemos ante un mayor nivel de aculturación. En nuestro caso parece todo lo contrario: la nómina de los moriscos de 1569 en nada se asemeja a la de los cristianos viejos de 1565. Lo que llama poderosamente la atención es que la concentración onomástica entre los cinco nombres más utilizados de cada nómina sea casi siempre menor entre los moriscos. Asimismo, las frecuencias de cada uno de los nombres moriscos raramente coinciden con la de los demás cristianos ${ }^{140}$. Es más, muchos de los nombres de los moriscos ni se encuentran representados entre la población viejo-cristiana en Granada:

Cuadro 9. Nombres de moriscas del Albayzín (1569) ${ }^{141}$.

\begin{tabular}{rlrcc}
\hline & NOMBRE & FRECUENCIA & $\%$ ACUMULADO & CASOS \\
\hline 1 & María & $31,50 \%$ & 31,50 & 86 \\
2 & Isabel & $27,11 \%$ & 58,61 & 74 \\
3 & Luzía & $9,16 \%$ & 67,77 & 25 \\
4 & Elvira & $5,86 \%$ & 73,63 & 16 \\
5 & Beatriz & $4,76 \%$ & 78,39 & 13 \\
6 & Leonor & $4,76 \%$ & 83,15 & 13 \\
7 & Inés & $3,66 \%$ & 86,81 & 10 \\
8 & Catalina & $2,93 \%$ & 89,74 & 8 \\
9 & Brianda & $1,83 \%$ & 91,57 & 5 \\
10 & Francisca & $1,83 \%$ & 93,40 & 5 \\
11 & Angela & $1,47 \%$ & 94,87 & 4 \\
12 & Guiomar & $1,10 \%$ & 95,97 & 3 \\
13 & Juana & $0,73 \%$ & 96,70 & 2 \\
& Otros & $3,30 \%$ & 100,0 & 9 \\
\hline & Total & $\mathbf{1 0 0 , 0} \%$ & & 273 \\
\hline
\end{tabular}

140. Por ejemplo, entre los cristianos viejos, Juan es el nombre más común con una frecuencia de $20,41 \%$, mientras que ocupa el puesto séptimo entre los moriscos con un escaso 5,84\% de la muestra de nombres de varones. Asimismo, Lorenzo es el segundo apelativo más común entre los moriscos con el 12,77\% del elenco masculino, mientras que apenas alcanza el 0,51\% de la nómina masculina cristiano-vieja y no figura ni entre los 20 nombres más populares.

141. A partir de las nóminas del Legajo L-6-57 del Archivo de la Alhambra trascrito en J. MARTínez RUIZ, «Visita a todas las casas...», 1986, pp. 107-135, se ha podido efectuar el cómputo onomástico. A diferencia del cuadro de los nombres masculinos de los moriscos, se ha tenido que ampliar la muestra de parroquias para el caso femenino debido a la escasa mención de mujeres comparada con la de los hombres. Los 273 nombres femeninos han sido cribados a partir de las nóminas de las parroquias exclusivamente moriscas: San Blas, San Martín, San Ildefonso, San Bartolomé y San Lorenzo, San Salvador, San Pedro y San Pablo, San José, San Gregorio, San Luis y San Nicolás. 
Los moriscos cuentan con 16 nombres comunes castellanos que no figuran entre la muestra de los demás cristianos de la ciudad ${ }^{142}$. Es cierto que varios

Cuadro 10. Nombres de cristianos viejos de Granada (1565) ${ }^{143}$.

\begin{tabular}{rlrcr}
\hline & NOMBRE & FRECUENCIA & $\%$ ACUMULADO & CASOS \\
\hline 1 & Juan & $20,41 \%$ & 20,41 & 119 \\
2 & Pedro & $11,15 \%$ & 31,56 & 65 \\
3 & Alonso & $10,29 \%$ & 41,85 & 60 \\
4 & Diego & $9,26 \%$ & 51,11 & 54 \\
5 & Francisco & $7,89 \%$ & 59,00 & 46 \\
6 & Fernando & $4,46 \%$ & 63,46 & 26 \\
7 & Xristobal & $3,26 \%$ & 67,92 & 19 \\
8 & Bartolomé & $3,09 \%$ & 71,01 & 18 \\
9 & Luis & $2,92 \%$ & 73,93 & 17 \\
10 & Andrés & $2,40 \%$ & 76,33 & 14 \\
11 & Gaspar & $2,40 \%$ & 78,73 & 14 \\
12 & Martín & 80,79 & 12 \\
13 & Miguel & $2,06 \%$ & 82,68 & 11 \\
14 & Antonio & $1,89 \%$ & 84,40 & 10 \\
15 & Gonçalo & $1,72 \%$ & 85,94 & 9 \\
16 & Rodrigo & $1,54 \%$ & 87,48 & 9 \\
17 & Melchor & $1,54 \%$ & 88,68 & 7 \\
18 & Sebastián & $1,20 \%$ & 100,0 & 62 \\
\hline & Otros ${ }^{144}$ & $1,03 \%$ & 100,0 & 583 \\
\hline & Total & $12,84 \%$ & & 6 \\
\hline
\end{tabular}

142. Los 16 nombres moriscos que no se ven reflejados entre la población cristiano-vieja son Agustín, Ambrosio, Benito, Clemente, Felipe, Graviel, Gómez (como nombre de pila), Înigo, Jorge, Lope, Lucas, Pablo, Rafael, Salvador, Tomás y Zacarías.

143. El cómputo onomástico se ha efectuado a partir de las nóminas del Legajo L-6-58 del Archivo de la Alhambra trascrito por J. MARTínEZ RUIZ, «Visita a todas las casas de cristianos viejos de Granada en 1965. Inventario de armas (Hidalguía, profesiones, oficios) II», Cuadernos de la Alhambra, 27, 1991, pp. 263-309. Se han seleccionado las parroquias cuya población era completamente cristiano-vieja: San Matías, Santiago, de la Magdalena, Santa Ana.

144. Baltasar, García y Jerónimo figuran cinco veces cada uno (0,86\% de la muestra por nombre); Mateo consta cuatro veces $(0,69 \%)$; Bernardino, Lázaro, Lorenzo, Marcos y Ramón se reseñan tres veces cada uno (0,51\%); Domingo, Alberto, Álvaro, Blas, Esteban, Gil, Gregorio, Martín, Nicolás figuran dos veces cada uno (0,34\%); y Alejo, Aparicio, Asensio, Bernabé, César, Damián, Ginés, Julián, Leandro, Nuño, Santos, Simón, Tello y Tomé aparecen una sola vez $(0,17 \%)$. 
nombres que no se reproducen en el censo cristiano-viejo tienen resonancias eclesiásticas: nombres de los padres de la Iglesia, de fundadores de órdenes religiosas, evangelistas, apóstoles, arcángeles... Es muy probable que estos nombres fueran elegidos de forma explícita por los clérigos encargados de su bautismo. Sin embargo, por una parte su incidencia -como se puede contrastar en el cuadro 8- no es muy pronunciada entre los moriscos (de uno a cinco casos por nombre), y por otra parte el cuadro 10 de cristianos viejos de 1565 también contiene nombres que no aparecen en la nómina morisca y aunque reflejen generalmente otro tipo de modas (como ciertas influencias extranjeras), algunos también sugieren resonancias eclesiásticas. Es decir, aunque una parte limitada del elenco de nombres moriscos es evidentemente de elección simbólica ajena, la mayor parte del acervo antroponímico no responde necesariamente a una imposición con sentido evangelizador.

La onomástica masculina morisca representa una alta variedad, una no excesiva concentración entre los apelativos más comunes, y un repertorio que no siempre coincide con la de los cristianos viejos ni en frecuencia y, a veces, ni en el propio nombre. Posiblemente estemos ante un patrón de consciente multiplicación onomástica de los moriscos varones, sea por elección propia de la familia morisca o por sugerencia del clero. No obstante, la proliferación resulta algo errática por no seguir patrones existentes en la comunidad que tendría que ser de referencia -los cristianos viejos asentados en Granada-. Cabe preguntarse si no estamos ante una simulación de una asimilación por motivos de defensa contra instituciones e individuos que pudieran sospechar de prácticas cripto-islámicas.

¿Hubo una tentativa de esconderse detrás de un amplio surtido de apelativos cristianos, no tanto para evitar ser identificado como morisco -como veremos, la mayoría mantenían orgullosamente su seña de identidad árabe en el sobrenombre- sino para no suscitar sospechas sobre la sinceridad de su fe cristiana ${ }^{145}$ ?

Algo similar detectó Laliena Corbera para el caso de los moriscos aragoneses de Illueca (Zaragoza) en 1526, aunque por lo exagerado de la diversidad onomástica puede que llegaran a destacar involuntariamente del resto de la población cristiana incurriendo en una peligrosa contradicción ${ }^{146}$. Si el propósito de muchos moriscos de otras partes de la Península Ibérica era aparentar de forma consciente una asimilación cultural y espiritual, el caso de la Gra-

145. Como hemos dicho más arriba, se ha afirmado que a muchos moriscos se les asignó el nombre de un supuesto padrino viejo-cristiano (debido a las múltiples normativas que lo exhortaban). Éste no fue el caso para la inmensa mayoría de los musulmanes del Albayzín convertidos en 1500, como ya se ha mostrado, y probablemente, a lo largo del siglo XVI, el mismo nombre del padrino viejo-cristiano -suponiendo que lo hubiera en la mayoría de los casos- le sería dado a pocos neófitos. Si fuera de otra manera, la población morisca reflejaría mejor la onomástica castellana de su ciudad, aunque con una mayor concentración y menor variedad, algo que no se constata en las nóminas de 1569.

146. C. Laliena Corbera, op. cit., pp. 164-165. 
nada morisca se distingue por limitarse a la integración religiosa, la que ver-daderamente importaba a ojos de los cristianos; o al menos, así pensaron ilusamente los moriscos en un primer momento ${ }^{147}$.

Con respecto a la evolución de las nóminas femeninas ocurre precisamente el fenómeno contrario, pues su acervo apenas crece y la concentración permanece altísima ${ }^{148}$. Muchos nombres cristianos y muy variados les sirven a ellos, pero pocos les bastan a ellas. Percibimos una división sexual de los patrones onomásticos que pudiera explicarse por la distinta función que cada género adopta en la comunidad morisca. Se puede hablar de los moriscos varones como interlocutores entre la comunidad cristiana vieja y su comuni$\mathrm{dad}^{149}$. Son los que acaparan las funciones en el ámbito público y entran en contacto con los cristianos viejos, o al menos están a la vista de estos cristianos.

Sin embargo, sería una simplificación desmedida reducir el papel de la mujer casi exclusivamente al ámbito doméstico. Ellas también asumían responsabilidades económicas en el sector artesanal, comercial y agrícola; quizás no eran tan visibles como los varones y probablemente muchas de sus tareas económicas no les exigían entrar en contacto directo con cristianos vie$\operatorname{jos}^{150}$. De hecho, la exigencia morisca de llevar la almalafa (el manto que hacía las veces de velo) permitiría a la mujer crear una cómoda barrera, aunque

147. Es preciso recalcar de nuevo que el hecho de querer disimular de esta manera no implica que todos -ni siquiera la mayoría- de los moriscos de Granada fueran cripto-musulmanes, pero sí entraña una conciencia por parte de dicho colectivo de que eran sospechosos de no ser buenos cristianos y que había que actuar para combatir el recelo de los cristianos viejos.

148. Por el momento, no contamos con ninguna nómina de cristianas viejas de Granada que pudiera utilizarse como punto de referencia para la segunda mitad del siglo XVI. En su estudio sobre el nombre cristiano de los moriscos, B. Vincent utilizó una nómina de bautizos de 1569 de la parroquia de San Cecilio. Desafortunadamente, por una parte, no se trata de un elenco onomástico completo; por otra, la parroquia de San Cecilio es mixta y no siempre es posible distinguir a un cristiano viejo de uno nuevo; por último, la muestra se refiere a un segmento demográfico de recién nacidos, de una generación posterior a la que se analiza en nuestras nóminas moriscas de adultos cabeza de familia. Ver B. VINCENT, «El nombre cristiano de los moriscos...», pp. 35-38.

149. El propio Francisco Núñez Muley en su memorial hace una alusión indirecta a la diferencia de las actividades entre mujeres y hombres moriscos: "...son de los varones que andan en las calles y negoçian de contino entre cristianos viejos y sus naturales...”, F. NúÑEZ MULEY, «Memoria», p. XLI.

150. En nuestra nómina de 1500, existen sólo cuatro casos de trabajos atribuidos a mujeres y todos en el sector del servicio doméstico. Esto no es óbice para que otras mujeres participaran en los talleres que regentaba la familia aunque el titular fuera un varón; G. CARRASCO GARCÍA, op. cit., pp. 360-361. Tenemos constancia de que las mujeres ejercían la profesión de parteras en la Granada morisca, que a partir de 1511 le sería vedada - en teoría- por las autoridades castellanas: A. Domínguez ORTIZ y B. VINCENT, op. cit., p. 101. Asimismo, hay constancia de la importancia del papel de la mujer en la industria textil. Todas las casas moriscas de Granada tenían un telar. Además de esta aportación complementaria al salario doméstico, las mujeres también están presentes en los talleres artesanales del sector textil de la seda en concreto, así como en la agricultura y especialmente en el sector azucarero: B. VINCENT, «Las mujeres moriscas», en G. DUBY y M. Perrot (eds.), Historia de las mujeres en occidente, Madrid, Taurus, 1992, p. 587. 
sólo fuera psicológica, para esquivar a los cristianos viejos y evitar comunicarse con ellos ${ }^{151}$.

Generalmente, se ha hablado del hogar como el lugar privilegiado de la mujer morisca. Es un espacio que en principio está al margen de las miradas sospechosas. Al ser el ámbito donde se crían los niños, es igualmente un espacio de transmisión de cultura, y quien dice cultura dice también credo. Muchos de los ritos musulmanes que se atribuían a la comunidad morisca se efectuaban en el seno de una morada privada. Por una parte, los procesos inquisitoriales no sólo delatan a los individuos sospechosos de prácticas no-cristianas sino que también revelan los espacios donde se acometían estos ritos vinculados al pasado islámico. Aranda Doncel, en su estudio sobre los procesos inquisitoriales de los moriscos de Córdoba procesados en el último tercio del siglo XVI (probablemente muchos de origen granadino) saca a colación un caso prototipo de entre tantos: el de Ángela Hernández la Hardona, que fue "maestra y dogmatista de la secta de Mahoma y su casa era como una mezquita y que avisaba a los demás cuando caia el ayuno del Ramadán y las pascuas de moros"152.

Vincent asevera que las mujeres son las auténticas custodias de la tradición musulmana, así cultural como espiritualmente ${ }^{153}$. Tanto en el caso valenciano como en el granadino, se revela un doble patrón sexual también en la lengua hablada: ellas son más reacias que ellos a adoptar el romance de los cristianos viejos. Las moriscas se mantuvieron aferradas al árabe (esencialmente hablado, al ser la mayoría de la comunidad morisca analfabeta), aunque fuera sólo fruto del escaso contacto que mantenían las moriscas con los cristianos viejos ${ }^{154}$. Igualmente, Vincent afirma que las mujeres moriscas son responsables de pasar el testigo del saber de una generación a otra ${ }^{155}$.

151. En la Cédula Real del 7 de diciembre de 1526 que recoge las recomendaciones expuestas en la Congregación de la Capilla Real (Archivo de la Iglesia Catedral de Granada, Reales Cédulas, lib. II duplicado, fol. 70) se prohíbe el uso de la almalafa o cualquier otra prenda que oculte la cara. Tan extendido era este uso que la misma cédula exhorta a las mujeres viejo-cristianas a que no sigan esta moda. La aculturación aquí iba en dirección inversa a la que pretendían las autoridades castellanas: A. GALlego Burín y A. GÁmIR SANDOVAL, op. cit., pp. 202-203. Asimismo, el alegato de Francisco Núñez Muley contra estas medidas que se oponían a los hábitos tradicionales y en concreto al velo de la mujer ocupa gran parte de su memorial. Además de argumentar sobre el carácter intrínsecamente regional del traje, desvinculado de cualquier significado religioso, arremete contra el escarnio público que tienen que soportar las moriscas: “...mandan que desde que se pregono vayan las caras descubiertas para que todos hagan bulla dellas...", F. Núñez MuleY, «Memoria», p. XLIII.

152. Archivo Histórico Nacional, Inquisición, Legajo 1856, Expediente 33, citado en J. ARANDA DONCEL, «Las prácticas musulmanas de los moriscos andaluces a través de las relaciones de causas del Tribunal de la Inquisición de Córdoba», en A. Temimi (ed.), op. cit., pp. 20-21. Aranda Doncel concluye que los casos que él ha podido identificar en las fuentes "ratifican el importante papel de la mujer en el plano religioso", ibídem, p. 21.

153. B. VINCENT, «Las mujeres moriscas...», p. 588.

154. Ibidem, p. 589.

155. Ibídem, pp. 592-593. 
Asimismo, en sus investigaciones sobre la mujer morisca, Perry propone una nueva manera de concebir su papel y el espacio donde se circunscribe su actividad. Esta autora habla de la "politización del hogar morisco", que se convierte en un espacio de aprendizaje del Islam, al igual que de la transmisión de los valores culturales del colectivo morisco ${ }^{156}$. Basándose principalmente en testimonios moriscos de procesos inquisitoriales, Perry establece que en muchos de los casos en que los reos acusan a una persona de inculcar los preceptos islámicos, ésta acaba siendo una figura femenina de la familia ${ }^{157}$. Y el lugar por antonomasia de esta resistencia fue el hogar.

No hay que perder de vista las normativas castellanas que exigían a los moriscos mantener las casas abiertas, especialmente los días más susceptibles de celebración de la liturgia musulmana ${ }^{158}$. Recordemos el énfasis que hace Francisco Núñez Muley en su defensa a ultranza de la intimidad y la integridad de los moriscos granadinos y su propiedad. El caballero morisco critica las medidas, más por exigir que se expusieran a los peligros de hurto y violación de la privacidad, que por un peligro mayor, el inquisitorial, que contaba ya con suficientes recursos para inquirir en la ortodoxia cristiana de los granadinos ${ }^{159}$. La casa morisca se convirtió en foco de miradas suspicaces por el potencial que tenía de sustituir otros espacios de culto y docencia eliminados, como eran las mezquitas y las madrazas.

En otro orden de cosas, cabe destacar el paralelismo que existe entre la diferencia onomástica entre varones y mujeres y el contraste bien conocido en la forma de vestir de los moriscos. Es de nuevo Francisco Núñez Muley quien nos aporta el testimonio más revelador en su crítica contra las medidas que

156. M.E. Perry, «Moriscas and the Limits of Assimilation», en M.D. MEYERSON y E.D. ENGLISH (eds.), Christians, Muslims, and Jews in Medieval and Early Modern Spain. Interaction and Cultural Change, Notre Dame, University of Notre Dame Press, 2000, pp. 274-289; y M.E. PERRY, The Handless Maiden. Moriscos and the Politics of Religion in Early Modern Spain, Princeton, Princeton University Press, 2005, capítulo 3, y especialmente pp. 66-73.

157. Ibídem, pp. 79-80. Cabe también destacar el papel -ya no relegado al ámbito familiar sino de trascendencia más amplia- de la famosa Mora de Úbeda descrita por el Mancebo de Arévalo en varias de sus obras aljamiadas. Esta sabia mujer desempeñó cargos en la propia corte nazarí antes de la conquista de los Reyes Católicos y luego mantuvo un enorme prestigio entre los cripto-musulmanes estudiosos del Corán: ver NARVÁEZ CóRDOVA, «Estudio Preliminar», de su edición del Tratado [Tafsira], pp. 51-55; y L.P. HARVEY, «El Mancebo de Arévalo and his Treatises on Islamic Faith and Practice», Journal of Islamic Studies, 10:3, 1999, pp. 268-270.

158. Esta normativa queda reflejada en la Pragmática de 1566: “...y que en los días de bodas y velaciones tuviesen las puertas de las casas abiertas, y lo mismo hiciesen los viernes en la tarde y todos los días de fiesta”, en A. GALlego Burín y A. GÁmir SANDOVAL, op. cit., p. 274.

159. “...pues quedando las puertas aviertas y las dichas casa sin çerraduras, viene muy gran daño y suelta y livertad que se da a los ladrones y personas de poca conçençia, por çerrar las puertas no es para ofender a la santa fee católica... para el que tiene danada su yntinción, que lo puede hazer en qualquier tienpo que quiere secretamente y para el que hiziere lo que no deve contra la santa fee catolica, para esto son los señores ynquisidores para lo castigar como lo castigan", F. NúÑ̃z MulEY, «Memoria», pp. XLV. 
cercenan la libertad de hábito de las moriscas ${ }^{160}$. Queda bien claro que esta medida se dirige esencialmente a las mujeres, debido a que los varones adoptaron de forma generalizada el hábito castellano durante el reinado de Carlos $\mathrm{I}^{161}$. Núñez Muley procura convencer a las autoridades castellanas de que el cambio que importa es el del varón, quien sería el único responsable de la conservación de un supuesto criptoislamismo: "pues los varones an de mirar en esto y no las mugeres"162. La mujer morisca queda, según la astuta argumentación del portavoz de los moriscos, al margen de las sospechas, porque es el varón el que marca la pauta. Es plausible que ésta fuera la estrategia que utilizaron los moriscos para conservar sus últimas señas de identidad innegociables al quedar teóricamente inadvertidas las acciones de las mujeres ${ }^{163}$. Una lógica que de poco les serviría al verse desdeñadas las protestas de esta comunidad. Posiblemente, ésta fue la misma lógica que influyó en la divergencia onomástica entre moriscos y moriscas.

Esta diferenciación de género habla por una parte de un mayor apego atávico de las moriscas a las tradiciones culturales, y por otra de una menor interacción entre moriscas y cristianos viejos. Con todas las reservas que implica el uso de datos antroponímicos basados en una muestra parcial de la sociedad granadina, se puede avanzar la hipótesis de una cierta taqìyya onomástica por parte de los miembros masculinos de la comunidad, que son los que están en mayor medida expuestos a -y entran más en contacto con- la sociedad viejo-cristiana. Esta tendencia sugiere que, sin renunciar a su identidad árabe, al permanecer un alto porcentaje de sobrenombres que recuerdan su pertenencia a una

160. No es baladí el hecho de que a menudo hayan existido normas que, a la vez de restringir las formas de vestir, imponer un atuendo o exigir un distintivo sobre la ropa, también regulen el tipo de apelativo. El nombre es entendido como una seña imbuido de contenido socio-semántico, como el hábito que recubre el individuo y comunica unas características identitarias. En la Castilla bajo-medieval encontramos varios casos de normativas que aúnan al mismo tiempo restricciones en el vestir y en el apelativo de las minorías étnicas judías y mudéjares (como en las Cortes de Jerez de 1268 y las Cortes de Valladolid de 1351). Ver J.D. GONZÁLEZ ARCE, Apariencia y poder. La legislación suntuaria castellana en los siglos XIII-XV, Jaén, Universidad de Jaén, 1998, pp. 170-177.

161. R. ARIÉ, «Acerca del traje musulmán en España desde la caída de Granada hasta la expulsión de los Moriscos», Revista del Instituto de Estudios Islámicos en Madrid, vol. XIII, 1965-1966, reedición en R. ArIé, Études sur la civilisation de l'Espagne musulmane, Leiden, Brill, 1990, p. 137.

162. “...y para que vuestra señoria reberendisima este mas satisfecho e ynformado... en lo que toca a el avito y traxe o calçado de las mugeres naturales deste rreyno, si es avito o traxe o calçado que toca en fauor de la seta, o no coligirá vuestra señoria de que todos los onbres barones, viejos y moços y niños, an tomado y bestido y calçado todo el avito castellano; pues si fueran dañados sus corazones, avian de pensar que, mudado el avito dellos, avia de danar a su seta, pues los varones ende mirar en esto y no las mugeres", F. NúÑEZ MULEY, «Memoria», p. XLI.

163. Probablemente éste fue el mismo razonamiento que hicieron los musulmanes granadinos en 1499-1500 al bautizarse primero algunos varones, según atestiguan las nóminas estudiadas aquí, quizás como tanteo inicial, con la esperanza de que el resto de la familia (mujeres e hijos) se mantuvieran al margen de los dramáticos cambios. 
cultura previa, los moriscos pudieron justificar su ortodoxia cristiana con la ostentación de una respetable plétora de nombres cristianos. La otra cara de la moneda sería el limitado uso de los nombres cristianos por parte de las mujeres que veían menos necesidad de utilizarlos al estar relativamente recluidas en un contexto cultural (y religioso) morisco. Fueron, en gran medida, ellas las responsables de la transmisión de ese legado que se podía perpetuar dentro de los intersticios privados, auténtico dominio de las mujeres, pudiendo luchar por conservar las señas de identidad de las formas más inusitadas.

\section{LA EVOLUCIÓN DEL SOBRENOMBRE ÁRABE GRANADINO DE 1500 A 1569}

Si bien las nóminas de 1500 demuestran una gran riqueza onomástica del ism y del correspondiente nombre cristiano de cada individuo, no es menos relevante el importante elenco de sobrenombres árabes y cristianos que se reseñan en algo menos de un tercio de los $\operatorname{casos}^{164}$. Este indicador nos permitirá ver en primer lugar -en contraste con los sobrenombres de la nómina de moriscos de 1569- la realidad de los usos antroponímicos tal y como figuran en las nóminas originales de bautizos, en donde la reducción de la cadena onomástica árabe ha puesto en tela de juicio la autenticidad del apelativo árabe tal como fue reseñado por escribanos castellanos. En segundo lugar, nos permitirá evaluar ese proceso de aculturación que afectó a la comunidad morisca al cabo de dos o tres generaciones.

\section{SOBRE LA DISMINUCIÓN DEL ETNÓNIMO}

Los moriscos no fueron un colectivo homogéneo al conformarse en varios grupos étnico-culturales que, si bien compartían la mayoría de los rasgos culturales, mantenían vivos sus rasgos distintivos en las referencias onomásticas. Antes de abordar la población morisca mayoritaria, analizaremos brevemente las minorías de la antigua sociedad nazarí.

Aunque persisten en las nóminas de 1569 algunos etnónimos -o sobrenombres de tipo étnico-cultural- como el de Mudéjar, Negro, Moreno, o Gazi, lo hacen en menor grado que en 1500. Sobre la denominación de mudéjar, ya avanzamos en otro artículo una hipótesis sobre la diferenciación que caracterizaba a este colectivo frente al resto de la población nazarí. Muchos de los to-

164. Hay 501 individuos (30,76\%) en la nómina de 1500 que llevan, bien un sobrenombre árabe, bien un sobrenombre castellano, o ambos, aunque si eliminamos los ausentes aludidos sin nombre cristiano -y por tanto sin certeza de conversión- el número de individuos con sobrenombre desciende a 455 . 
ponímicos castellanos (u originarios de la Corona de Aragón) utilizados como sobrenombre podían ser atribuidos a los mudéjares al contar con una mayor aculturación por su crianza en los reinos cristianos y con una necesidad de distinguirse del colectivo morisco granadino ${ }^{165}$.

El caso de la minoría de origen sub-sahariano también es tratada en el mismo artículo, con la conclusión de que es preciso distinguir entre el grupo racial asimilado a la cultura musulmana -y en gran medida libre- y los esclavos recién llegados de África a través de la trata portuguesa y luego esencialmente castellana, aunque estos últimos no entrarían en la categoría de morisco propiamente dicho. En el caso de la nómina de 1569, el porcentaje de los que mantienen el distintivo onomástico negro o moreno ha bajado drásticamente del $2,46 \%$ al $0,44 \%$. Puede que sea un indicador de su mayor integración en esta población y su deseo de adquirir una identidad completa a través de un apellido auténtico que no sea un simple mote racial impuesto por los castellanos a la hora de su conversión. Las autoridades cristianas otorgaban a la mayoría de los esclavos un simple apelativo. A veces éste era seguido por un calificativo racial o jurídico que a menudo adquiría el mismo significado. Aunque no fuera algo generalizado, no sería desatinado pensar que, para muchos mo-riscos negros libres, cuanto antes cobraran un apellido castellano más rápido podrían deshacerse de ese estigma social ${ }^{166}$.

Por último, los gazíes eran descendientes de mercenarios del Norte de África que acudieron al reino nazarí de Granada para luchar en la guerra contra Castilla. Dado que se consideraban más tenaces en su afiliación religiosa, fueron sospechosos de difundir el cripto-islamismo por todo el reino después de su conversión formal ${ }^{167}$. Los gazíes africanos siguieron viniendo a la Península como cautivos de guerra y, a menudo, eran liberados por moriscos. En numerosas ocasiones, la Iglesia reclamó que todos los gazíes fueran expulsados de Granada como en 1523 y luego de nuevo en $1566^{168}$. Núñez Muley los defendió en su memorial de 1567 aduciendo su integración a través de matri-

165. G. CARrasco GARCía, op. cit., pp. 373-379. Con respecto a la esclavitud en la Granada morisca, ver A. MARTín CASARES, La esclavitud en la Granada del siglo XVI: género, raza y religión, Granada, Universidad de Granada, 2000.

166. Ibídem, pp. 366-373. Ver también, sobre las cuestiones relacionadas con la onomástica de los esclavos y la consideración social del colectivo negro, R. GONZÁlez ArÉVALO, La esclavitud en Málaga a fines de la Edad Media, Jaen, Universidad de Jaen, 2005, pp. 106-115.

167. N. CABrillana, Almería morisca, Granada, Universidad de Granada, 1982, pp. 23-24; y J. CARO BAROJA, op. cit., p. 94.

168. "Asimismo mandamos y defendemos que de aquí adelante ninguno de los gazís que haya sido o sea cautivo o rescatado, ni viva ni more ni esté ni ande por las dichas Alpujarras ni por la dicha costa de mar ni con diez leguas en derredor de ella, so pena de ser cautivo, porque tenemos información que son espías de los moros e hacen otros daños...", Archivo de la Iglesia Catedral de Granada, Reales Cédulas, lib. II duplicado, folio 70, doc. XXIV; publicado en A. GAllego Burín y A. GÁmir SANDOVAl, op. cit., p. 203. 
monios mixtos en la sociedad granadina ${ }^{169}$. Cabe preguntarse por qué los gazíes no cambiaron el sobrenombre que hacía de ellos un objetivo destacable para las autoridades civiles y eclesiásticas ${ }^{170}$. ¿Eran menos susceptibles a la aculturación -como indican las fuentes oficiales- y por consiguiente más reacios a renunciar a su identidad como orgullosa minoría entre los moriscos, a pesar de las consecuencias que su visibilidad onomástica pudiera conllevar? No fueron, sin embargo, los únicos en renunciar a una mayor ocultación onomástica.

\section{Cuadro 11. Comparación de tipos de sobrenombres árabes de los moriscos en 1500 y en 1569.}

\begin{tabular}{|c|c|c|c|c|}
\hline $\begin{array}{l}\text { ELEMENTO } \\
\text { ONOMÁSTICO ÁRABE }\end{array}$ & $\begin{array}{c}\text { FRECUENCIA } \\
1500\end{array}$ & $\begin{array}{l}\text { CASOS } \\
1500\end{array}$ & $\begin{array}{c}\text { FRECUENCIA } \\
1569\end{array}$ & $\begin{array}{c}\text { CASOS } \\
1569\end{array}$ \\
\hline$N a s a b^{171}$ & $25 \%$ & 94 & $23 \%$ & 71 \\
\hline Nisba geográfica & $39 \%$ & 147 & $37 \%$ & 111 \\
\hline Nisba tribal & $4 \%$ & 13 & $4 \%$ & 11 \\
\hline Laqab oficio ${ }^{172}$ & $19 \%$ & 73 & $22 \%$ & 69 \\
\hline Laqab mote & $9 \%$ & 35 & $11 \%$ & 34 \\
\hline Kunya & $5 \%$ & 19 & $4 \%$ & 10 \\
\hline Indeterminado ${ }^{173}$ & {$[14 \%]$} & {$[63]$} & {$[17 \%]$} & [65] \\
\hline Total & $99 \%$ & 381 & $99 \%$ & 306 \\
\hline
\end{tabular}

169. "Y en lo que dize la dicha prematica sobre lo de los gazies y alarabes que se avian de salir deste rreybno por los ynconvinientes de su conversaçion con los naturales, y esto fue mandado algunas vezes e no se efectuo ni se cumplio ni se executo... agora... seria gran cargo de consiençia, porque la mayor parte de los susodichos son ya naturales y medios naturales que casaron y les naçieron hijos e nyetos e casados, y esto es muy notorio”, F. NúÑEZ MULEY, «Memoria», p. XLVIII.

170. Esta tendencia ya fue señalada en J. MARTínEZ RUIZ, «Antroponimia morisca...», p. 1948.

171. Bajo la categoría onomástica nasab se ha computado también los segundos ism. Pese a que no es raro, como hemos visto, que los árabes llevaran varios ism, se ha considerado estos ism como un nasab cuya partícula patronímica, $i b n$, se ha omitido, como es frecuente ver en la onomástica tradicional árabe.

172. Ha sido de gran utilidad la magnífica obra monográfica sobre los oficios a través del mundo islámico medieval de M. SHATZMILlER, Labour in the Medieval Islamic World, Leiden, E.J. Brill, 1994. Para otro repertorio de laqab relacionado con la Granada morisca ver J. MARTínEZ RuIZ, «Los laqab de oficio en la Granada morisca y en la tradición andalusí», Al-Qanțara, XI, 1990, pp. 343-365.

173. Los casos donde no se ha podido identificar el tipo de componente onomástico quedan reflejados entre paréntesis, y el porcentaje de los componentes identificados se ha calculado sin tener en cuenta los casos indeterminados para poder contrastar proporcionalmente las frecuencias de las dos nóminas. 


\section{LA AUTENTICIDAD DEL APELATIVO ÁRABE EN}

\section{LAS NÓMINAS CASTELLANAS}

Para comparar los sobrenombres de origen árabe de una y otra lista es esencial dividirlas en categorías por tipo de apelativo, según vimos en la descripción de la cadena onomástica árabe. Si contrastamos los distintos elementos de esta cadena que figura como sobrenombre árabe en la nómina de 1500 con el documento de 1569 nos hallamos ante una equiparación de las frecuencias de los elementos onomásticos que a primera vista resulta algo sorprendente porque diverge de las hipótesis propuestas por otros autores en el pasado sobre los cambios en el nombre morisco. Si consultamos el cuadro 11 donde figuran los diversos componentes del nombre árabe, vemos cómo de manera sistemática el nasab, la nisba geográfica, la nisba tribal, el laqab de oficio, el laqab de mote, y la kunya de la nómina de 1500 y la de 1569 coinciden en porcentaje con ligeras discrepancias anecdóticas que entran dentro del margen de error del cómputo. Estas convergencias tienen lugar a pesar de que los individuos de la muestra de 1569 no están necesariamente relacionados con los de 1500, y que los sobrenombres en su mayoría no son los mismos en ambas muestras.

El hecho de que mantengan las mismas proporciones de los componentes onomásticos nos lleva a pensar que las estructuras onomásticas árabes documentadas en 1500 no fueron meras selecciones arbitrarias y abreviadas de la auténtica designación completa de cada individuo. Recordemos que, a diferencia del nombre de pila castellano, la determinación de los sobrenombres árabes nunca fue responsabilidad de los sacerdotes, notarios o escribanos que llevaron a cabo los bautizos. No eran más que adiaphora que no incumbían (al menos teóricamente) a la teología. Además, los sobrenombres árabes que están documentados en la nómina de 1500 servían para identificar al individuo antes de la conversión. Una vez recibida el agua bautismal, se le otorgaba un nombre castellano (y en algunos casos un sobrenombre castellano), pero raramente se reiteraba el sobrenombre árabe junto con el nuevo nombre. De ahí que la población granadina no pudiera interpretar que el sobrenombre árabe documentado en la nómina fuera considerado un apelativo oficialmente reconocido y, por tanto, susceptible de ser fijado, fosilizado, y transmitido a las siguientes generaciones. Si el sobrenombre en 1569 está ya fosilizado es porque los moriscos, en generaciones previas, eligieron conscientemente este componente onomástico sobre otro como el más representativo de su identidad individual o familiar, a pesar de haber perdido en muchos casos su contenido semántico.

Precisamente, con respecto a la ausencia de significado de ciertas partes del apelativo, merece detenerse brevemente sobre el laqab de oficio como caso paradigmático que permite ser, hasta cierto punto, contrastado. Se ha dicho que las comunidades mudéjares utilizaban ya un laqab que debía identificar la profesión del individuo pero que debido a la aculturación había perdido su 
significado literal para quedar fijado como un apellido meramente nominal ${ }^{174}$. Lo mismo se ha dicho para la evolución antroponímica de los moriscos de Granada en la segunda mitad del siglo XVI, donde esa falta de correspondencia entre el oficio del individuo y su laqab se atribuye a la evolución del nombre propiciado por factores que indujeron su fosilización.

Al examinar los individuos de la nómina de 1500 que llevan tanto laqab de oficio y la mención (en castellano) a su oficio del momento, encontramos varios casos que no coinciden y ni uno solo en donde coincida el oficio documentado con la traducción castellana del laqab en cuestión (aunque los casos donde ambas informaciones son proporcionadas son bastante escasos $)^{175}$. No se puede descartar que algunos granadinos efectivamente ocuparan estos oficios previamente y que, debido a los cambios socio-económicos que afectaron a la antigua capital nazarí, fueran obligados a buscar cualquier otro tipo de empleo, aunque su oficio real siguiera siendo el que le identificaba a través del laqab: un carpintero seguiría siéndolo aunque se viera forzado a trabajar en otro sector. No obstante, no hay que descartar que esta cristalización del laqab tuviera precedentes en la misma sociedad nazarí antes de sucumbir a presiones socioculturales que alterarían la lógica antroponímica árabe ${ }^{176}$.

La investigación histórica sobre la antroponimia árabe, tan condicionada por las largas cadenas reflejadas en los diccionarios bio-bibliográficos y en otros documentos oficiales, debería explorar la existencia de un apelativo cotidiano y común utilizado por un amplio sector de la sociedad, y no sólo por la elite de donde se extrae la mayor parte de los ejemplos analizados en los estudios onomásticos. El uso abreviado del nombre árabe debe interpretarse como una forma válida -no necesariamente impuesta o distorsionada por una autoridad externa a la comunidad- y como una práctica antroponímica que satisface las necesidades de identificación de una gran parte de la población musulmana, al menos en el contexto granadino previo a cualquier conversión y potencialmente aplicable al resto de la Península Ibérica con sus debidos matices. Esto no implica que dichos individuos carecieran de otros elementos de la cadena onomástica, sino que en su forma comprimida algunos elementos prevalecen sobre otros.

174. Esto también se ha constatado en el caso de los mudéjares portugueses; F. LOPES DE BARROS, «The Identification...», p. 219.

175. Por ejemplo, encontramos en el asiento [358] a Mahamed Alarife/ Pedro que es labrador; en el asiento [438], Hamed el Najar/Françisco que es espadador; o en el asiento [904], Mahamad Adaraz/Fernando que es labrador.

176. Martínez Ruiz constata el hecho de que los laqab no siempre hicieron referencia a los oficios verdaderos de los individuos que lo utilizaban como apelativo en la época morisca, ni entre la sociedad andalusí: J. MARTínEZ RuIZ, «Los laqab de oficio...», p. 357. 


\section{LA CUESTIÓN DE LA ACULTURACIÓN A PARTIR DEL} SOBRENOMBRE MORISCO

$\mathrm{Si}$, a lo largo del siglo XVI los moriscos granadinos eligieron los distintos tipos de componentes onomásticos en una proporción constante, cabe pensar que la cultura -al menos aquella reflejada en la seña de identidad onomásticade 1569 había cambiado muy poco desde antes de las conversiones de 1500. Aunque Caro Baroja postuló una transformación del sobrenombre morisco enfocado hacia un mayor uso de la nisba y el laqab como apellidos, no pudo contar con este valioso punto de comparación que nos permite matizar ahora las transformaciones y las permanencias culturales ${ }^{177}$.

$\mathrm{Al}$ considerar la proporción de sobrenombres árabes y castellanos entre los moriscos constatamos que hubo cierta variación en las siete décadas que separan las muestras. En 1500 hubo un 32\% de sobrenombres propiamente cristianos entre los conversos que portaban algún tipo de sobrenombre (148 casos) ${ }^{178}$ y un $67 \%$ de individuos con sobrenombres árabes (307 casos) pero sin apellido cristiano. En 1569 el porcentaje de sobrenombres castellanos o catalanes es de un 44\%, mientras que el 56\% de individuos (334 casos) llevan sobrenombres árabes de forma exclusiva (y otro 6,5\%, o 39 casos, lo llevan junto a sobrenombres romances). Solamente un $12 \%$ más de la población morisca ha incorporado un sobrenombre cristiano, mientras que un 4,5\% menos mantiene un apellido árabe. Debemos precisar que el aumento en el uso del apellido castellano del $12 \%$ es un mínimo, pudiendo ser factible una tasa algo más elevada según la interpretación de los datos estadísticos ${ }^{179}$. Aunque leve, este cambio puede ser indicativo de cierta aculturación por parte de un sector de la población morisca. No obstante, después de varias generaciones y tantas medidas contra el uso del sobrenombre árabe puede igualmente considerarse representativo del fracaso castellano en su afán por asimilar a los moriscos granadinos ${ }^{180}$. Es más, si consideramos el hecho de que algunos de los sobrenombres cristianos eran -al igual que muchos nombres personales- nada más que máscaras o velos para cubrir el verdadero sobrenombre árabe, el porcentaje de la población morisca que se ve sinceramente reflejada en el sobrenombre castellano sería posiblemente más exiguo.

177. J. CARo Baroja, Los moriscos del reino..., pp. 114-115.

178. De estos individuos con apellido cristiano, dos terceras partes tienen documentado el nombre árabe previo a la conversión.

179. Es preciso apelar a la cautela metodológica con respecto al uso de los apellidos árabes entre los individuos que figuran en las nóminas de 1500 sin apellido explícito. Es probable que estos individuos siguieran utilizando el apellido árabe que desconocemos, por lo que el porcentaje de apellidos castellanos entre la población convertida en 1500 sería considerablemente menor. Si esto se llegara a confirmar, el incremento del uso del apellido castellano en 1569 sería algo más elevado que el $12 \%$.

180. En este sentido, discrepamos de la afirmación expresada por Areces Gutiérrez que sugiere que la política de Felipe II sobre la cristianización del nombre y apellido morisco "tuvo su efectividad en cuanto a la eliminación de pervivencias tradicionales", A. ARECES GUTIÉRREZ, op. cit., p. 672. 
Muchos de los sobrenombres castellanos asignados durante la conversión de 1500 tienen resonancias linajudas como de Aguilar [1014], de Acuña [970], de Padilla [932], o hasta Hurtado de Mendoza [1076], lo que podría indicar la presencia de algunos nobles como padrinos en los bautizos aunque carecemos de un rastro documental suficiente para confirmar esta norma. Sin embargo, no por pertenecer a la jạsșa, o a otra clase encumbrada, los granadinos conversos llevaban un sobrenombre altisonante o un sobrenombre cualquiera. De hecho, muchos individuos a los que se les confería el trato de don o doña recibían sólo un nombre de pila en las nóminas de la conversión ${ }^{181}$. Igualmente, los artesanos y agricultores tienen tanta probabilidad de recibir un sobrenombre castellano y hasta un apellido de reconocido abolengo que los que tienen un mayor estatus social en esta primera instancia.

Quizás lo que más destaca de los apellidos romances es, por una parte, la proporción de tipos de apelativos que de nuevo se mantienen más o menos constantes entre las dos fechas de las muestras: apellidos toponímicos o antropotopónimos, $27 \%$ en 1500 y 21\% en 1569; patronímicos, $27 \%$ y 29\%; apellidos de oficio, $1 \%$ y $1,5 \%$; apellidos de mote, $1 \%$ y $2 \%$; otros apellidos $44 \%$ y $46 \%$. Sin embargo, esta escasez de variación tiene sentido en tanto en cuanto el incremento en el uso del apellido romance es relativamente exiguo. Por otra parte, con respecto al uso de los apellidos toponímicos romances, constatamos la preponderancia absoluta de topónimos no-granadinos que constituyen el $90 \%$ de los antropotopónimos tanto en 1500 como en 1569. Es decir, estos apellidos fueron impuestos desde fuera y no reflejan un vínculo telúrico autóctono, ni un esfuerzo por traducir la nisba geográfica árabe que refleja contundentemente topónimos del territorio donde estuvo asentado el antiguo emirato nazarí. Igualmente, no hay voluntad de trasladar los laqab de oficio o de mote árabe al castellano puesto que representan entre el 1\% y $2 \%$ de los apellidos romances, mientras que su correspondiente árabe ocupa entre un $28 \%$ y 33\% de los sobrenombres árabes.

En lo que respecta a los nombres con tres elementos (es decir, un nombre de pila más un doble sobrenombre), para la nómina de $1569^{182}$ no hay más que un $8 \%$ de individuos que los utilizan, o un total de 46 casos: siete casos tienen dos nombres castellanos, dos casos tienen dos nombres árabes, y 37 siguen el patrón bimembre mixto, reduciéndose de hecho esta modalidad sincrética a un $6 \%$ del total de la población. Esta opción minoritaria no supone forzosa-

181. La onomástica específicamente de la jāšša sigue una lógica ligeramente diversa que aquí no ha sido considerada debido a la naturaleza de las fuentes que se han utilizado y la ausencia de un repertorio más amplio para este segmento demográfico.

182. La nómina de 1500 apenas cuenta con algunos sobrenombres dobles, aunque estas nóminas no muestran la elección de sobrenombres mixtos o con componentes árabes, debido a que figuran separados los nombres y sobrenombres árabes por una parte y los nombres y sobrenombres castellanos por otra. 
mente una decantación ideológica. Por una parte, podría interpretarse como una actitud cauta que, a la vez que garantiza las señas de linaje árabe que los ubican dentro de la comunidad morisca, les permite ostentar adicionalmente un apellido castellano que los vincula firmemente a la grey cristiana. Por otra parte, puede interpretarse como una manifestación de aculturación mestiza donde la adopción de nuevas señas no tiene por qué borrar las originales.

No obstante, la lógica que regía la elección del sobrenombre castellano y la del sobrenombre árabe era independiente. El sincretismo se manifestó en la utilización yuxtapuesta de dos sistemas onomásticos autónomos, sin que se detecte un trasvase de uno al otro, es decir, sin que un único sobrenombre incluya elementos de ambos sistemas onomásticos. Si bien se ha identificado este híbrido onomástico en limitadísimos sobrenombres del censo morisco de 1569 -por ejemplo pueden incorporar la partícula de filiación del nasab junto a un apellido castellano (como Miguel Beni Mendoça, Alonso Beni Pérez) - no constituyen más del 0,3\% de los apelativos, por lo que debe ser considerado excepcional y nada representativo de los patrones dominantes. Ciertos tipos de sincretismo onomástico estuvieron más difundidos entre las poblaciones mudéjares castellanas, portuguesas o aragonesas en la Baja Edad Media. Estas comunidades mudéjares habían perdido parcial o completamente su idioma árabe y fueron compelidas a adaptar el sistema onomástico a la lengua hegemónica por necesidad de conservar ciertos vestigios de sus señas culturales árabes. Por el contrario, la comunidad morisca de Granada aún no había sucumbido a la imposición lingüística castellana y la aculturación se limitó a integrar elementos ajenos a sus señas sin necesariamente transformar los componentes originales ${ }^{183}$.

\section{EL SISTEMA ONOMÁSTICO DÚPLICE VERSUS EL SISTEMA MIXTO}

Ciertos autores insisten en la existencia de dos ámbitos antroponímicos completamente separados que se manifiestan a través de un sistema dual de designación personal, donde el sistema clandestino árabe servía para mantener la posición social del individuo a partir del linaje $\mathrm{e}^{184}$. Es cierto que los moriscos se sirvieron de un doble sistema onomástico para el ism, pero la posición social se podía conservar con el uso del sobrenombre árabe oficial. Si el sobrenombre se hubiera reducido al ámbito del secretismo inherente al núcleo del hogar privado y los reducidísimos espacios donde podían esporádicamente reunirse y expresarse en libertad, sin la amenaza del furtivo delator que velaba por la orto-

183. La trasformación quizás esté en la fosilización de los elementos de la cadena onomástica árabe que conforman el sobrenombre morisco de origen árabe. No obstante, esta afirmación queda relegada al ámbito de la especulación hasta que se investigue el uso de estos componentes dispares como reflejo del linaje o de la familia.

184. Ver, por ejemplo, A. Hess, The Forgotten Frontier: A History of the XVIth Century Ibero-African Frontier, Chicago, 1978, pp. 143-144. 
doxia de toda la grey, el valor del sobrenombre secreto (especialmente el nasab genealógico y la nisba tribal) como soporte de la memoria del linaje perdería parcialmente su sentido. El linaje cobra fuerza mientras es públicamente difundido, conocido y reconocido. Pese a lo estrechas que pudieran ser las relaciones sociales en la ciudad de Granada, el disimulo onomástico inevitablemente tuvo que influir en la alteración de la memoria de los linajes agnaticios tradicionales después de ser ocultados durante varias generaciones. Por esta razón, la creación del apelativo morisco sincrético tenía un propósito intrínseco: reforzaba la seña de identidad a través de nuevos códigos que conservaban la pertenencia familiar.

El doble sistema onomástico evidentemente existió tal como dejan entrever los testimonios inquisitoriales y las crónicas de la época, donde los nombres árabes subrepticios conviven con -y a veces inadvertidamente borran- los apelativos cristianos, ya que estos últimos perdieron totalmente su sentido en lo más profundo del hogar doméstico, último resquicio de libertad para la cultura islámica. No obstante, la taqìya onomástica no elimina la necesidad de enfatizar ciertos elementos de su identidad. Estos elementos son los que permiten tejer las relaciones sociales entre moriscos como un indicador del linaje. Como ya se ha mencionado, la importancia de la 'asabìyya, es decir, la solidaridad agnaticia, en las relaciones sociales de los musulmanes pervivió, aunque de forma accidentada, entre la comunidad morisca granadina ${ }^{185}$. Los moriscos llegarían a hacer virtud de la necesidad creando un nuevo sistema onomástico -lícito en un principio- con el sobrenombre. Estos apelativos no eran necesariamente vestigios de nisbas tribales o la típica cadena genealógica, sino más bien otros elementos que, fosilizados o no, reemplazaron probablemente antes de la conversión esos marcadores tradicionales cuyo código escapaba a los castellanos pero era inteligible para los cristianos nuevos.

Caro Baroja ya identificó unos patrones onomásticos basados en los nombres de los moriscos a partir de los textos que narraban la sublevación de las Alpujarras. Muchos de los protagonistas sobre los que están basadas sus reflexiones habían cambiado su nombre oficial durante la rebelión y, por consiguiente, no reflejaban necesariamente la antroponimia en uso por la mayor parte de la comunidad morisca granadina, sino más bien la antroponimia deseada como acto de desafío. En otras palabras, estos nombres no siempre dejan entrever lo que se escondía tras el velo de la taqìyya onomástica. A pesar de este problema contextual en la determinación de patrones onomásticos, Caro Baroja acierta al identificar, como rasgo más típico de los sobrenombres, el uso de un toponímico como base de un linaje, además de la proliferación de los motes fosilizados con la función de identificar un vínculo familiar ${ }^{186}$.

185. J. CARo BARoja, Los moriscos del reino..., pp. 73-83.

186. Ibídem, p. 114. 
Es otra forma de decir que, al desaparecer el nasab original (el patronímico), echan mano de otros elementos propios de la cadena onomástica tradicional árabe como es la nisba geográfica o el laqab, y así -a veces vaciándolo de su contenido semántico- recrean un nuevo cognomen que les vincula a un linaje.

Esta es la razón por la que Francisco Núñez Muley, como hemos señalado, protesta ante la perentoria prohibición del sobrenombre árabe y él mismo expone su función inminentemente social: el colectivo perdería su memoria acarreando el resquebrajamiento de lo que quedaba de su organización social, ya de por sí degradada ${ }^{187}$. A lo largo del siglo XVI, no todos los moriscos peninsulares utilizaron un sistema dúplice de designación -uno privado y otro público- pero al menos el nombre oficial era en su mayoría un sistema mestizo.

Este sobrenombre que bebía de ambas tradiciones lingüísticas pudo mantenerse en parte gracias a que el apellido no infringía los preceptos católicos y, como hemos dicho antes, desde los bautismos masivos, los sobrenombres castellanos constituyeron menos de un tercio del total. Esta situación habría facilitado una transición a unas estructuras onomásticas mixtas a pesar de las prohibiciones posteriores al sobrenombre árabe, que no parecen haber afectado demasiado a la antroponimia morisca, al menos hasta que los moriscos fue-ran expulsados de Granada.

Hasta qué punto esa aculturación parcial y la taqīyya onomástica afectaron negativamente la utilización privada del ism es algo más difícil de determinar. Probablemente, de nuevo, habrá que apoyarse sobre la explicación lingüística: mientras el uso del árabe se mantuvo como lengua materna y cotidiana entre la mayor parte de la población -como lo fue en Granada-, el ism fluiría naturalmente como en el caso de los mozárabes toledanos cuatro siglos antes ${ }^{188}$.

Como ya apuntaron Domínguez Ortiz y Vincent con respecto al disimulo, "el oportunismo que representaba la taqiyya conducía a una selección entre los signos externos de adhesión al Islam; para conservar lo esencial, algunos fueron total o parcialmente abandonados" ${ }^{189}$. Asimismo, hasta algunos de los elementos conscientemente conservados resultarían afectados por la necesidad de mantenerlos en secreto. La taqìyya tiene el inconveniente de hacer vulnerables esas señas que pretenden conservar debido a la constante exteriorización de esos signos ajenos: la aculturación se acabaría imponiendo a pesar de la expresa renuencia de los moriscos. Si bien la evolución de los repertorios onomásticos moriscos del siglo XVI en Granada aún no muestran firmemen-

187. “...pues lo que toca en el sobrenombre castellano, e no mas perderse an las personas y los linajes moriscos, no sabran con quien tratan ni conpran ni casan, no conoçiendo el linaxe de rrayz; pues de que se sirve querer perderse tales memorias ansi en los abitos o traxes, como en los sobrenonbres, como en todo lo susodicho?", F. NúñEZ MULEY, «Memoria», p. XLVII.

188. Aunque aún en el caso mozárabe toledano, el uso del nombre podría haber resistido a la desaparición del idioma árabe: ver A. GONZÁlez PALENCIA, op. cit., pp. 129-130.

189. A. Domínguez Ortiz y B. Vincent, op. cit., p. 135. 
te ese efecto colateral perverso, todo sugiere que el nombre también estaría destinado a sucumbir, en mayor o menor grado, a las ineludibles pre-siones del patrón cultural hegemónico.

\section{CONCLUSIONES}

El análisis onomástico de una sociedad proporciona la posibilidad de determinar, en primer lugar, la manera en que son utilizados los apelativos por un colectivo en un momento dado y, en segundo lugar, permite establecer un modelo de evolución antroponímica como producto de otras manifestaciones sociales subyacentes. Pese a la cautela metodológica que se requiere a la hora de abordar un análisis histórico con este utensilio auxiliar, el estudio onomástico es valioso para ponderar transformaciones sociológicas difícilmente mensurables. La antroponimia ofrece nuevos derroteros para responder a las preguntas de siempre y permite formular nuevos interrogantes sobre cuestiones nada evidentes.

Es preciso replantearse cuál es el nombre de uso público y habitual de los musulmanes de cualquier estrato social en un contexto documental administrativo. A la luz de un sondeo de antropónimos árabes que figuran en una gran variedad de fuentes sobre musulmanes de la Península Ibérica (tanto en textos en lengua árabe, latín o romance) y teniendo en cuenta la perspectiva de arabistas, como Sublet, que preconizan la variabilidad del antropónimo árabe según el sujeto histórico y su contexto, la tradicional cadena onomástica árabe no es necesariamente la norma, sino todo lo contrario. La antroponimia árabe da fe de una gran flexibilidad con la que los individuos seleccionan distintas formas onomásticas (que en muchos casos no superan los dos elementos). La historiografía ha llamado la atención sobre la posible distorsión de los nombres árabes en las fuentes hispánicas sobre mudéjares. Sin embargo, si se acepta la premisa de la elasticidad onomástica de los apelativos islámicos, los antropónimos árabes supuestamente mediatizados en la documentación cristiana no tienen por qué estar a priori adulterados. Este es el caso de la muestra de las nóminas de bautizos de musulmanes granadinos en 1500 que se ha analizado aquí.

El estudio de la onomástica ofrece pistas muy sugerentes en cuanto a la cuestión fundamental de la aculturación de los moriscos granadinos, cuya andadura examinada nos lleva desde esos primeros momentos del siglo XVI hasta 1569, cuando iban a ser desterrados a otros paraderos castellanos lejos de su tierra natal. En la nómina de 1500 se constata una alta concentración onomástica del ism, que supera aun la de las propias muestras mudéjares. Esta elevada concentración de los ism asociados a los primeros momentos del Islam, según la teoría de la conversión de Bulliet, podría reflejar un mayor afán por reforzar sus señas etno-religiosas ante el ominoso predicamento de una inminente y definitiva conquista castellana de Granada a lo largo del siglo XV.

La conversión religiosa forzada de finales de 1499 y 1500 en Granada se concretaba en una nueva identidad expresada a través de un cambio antropo- 
nímico radical que afectaba esencialmente al nombre personal. El nombre castellano fue impuesto por los prelados responsables del bautismo masivo y de ninguna manera refleja una elección por parte de los conversos renuentes. El acervo onomástico castellano de los nuevos moriscos se ve reducido con respecto a sus propios apelativos árabes y a los de la población cristiano-vieja, aunque refleja de forma relativa los nombres en uso entre este colectivo a fines de la Edad Media. No se puede hablar de correspondencias generalizadas del paso del ism al nombre de pila, ni tampoco de nombres seleccionados como marcadores que pudieran revelar el origen etno-religioso de esta comunidad.

A pesar del cambio onomástico, a lo largo del siglo XVI, persistió el rito de las fadas con el propósito explícito de eliminar los efectos del bautismo e imponer un ism árabe a los niños moriscos. Mientras que las nóminas de 1500 y el censo de 1569 no expresan el uso combinado del ism árabe ilícito junto con el nombre cristiano, en contraste los testimonios inquisitoriales revelan la existencia común de lo que hemos denominado taqìyya onomástica: una práctica precaria que fomenta el riesgo de que las señas onomásticas de la diferencia se borren por el constante uso del disimulo en público. Por consiguiente, es factible que la aculturación formal acabara por imponerse -aunque muy lentamente- por el incesante hábito de fingir el apelativo.

La comparación diacrónica de los dos repertorios antroponímicos revela unos patrones evolutivos que sorprenden por la aparente incongruencia de la práctica onomástica entre hombres y mujeres. Los varones moriscos en 1569 habían adoptado un acervo mucho más variado con una concentración muy próxima a la de los cristianos viejos, pero con nombres y frecuencias divergentes. Por ello, no se puede hablar de aculturación como tal, sino posiblemente de la necesidad de manifestar explícitamente su auténtica conversión religiosa -aunque para muchos moriscos fuera sólo un mero simulacro-. El dimorfismo sexual se caracteriza por el hecho de que las mujeres moriscas siguieron un patrón diametralmente opuesto: el censo femenino de 1569 no muestra una ampliación antroponímica significativa con respecto a la de la nómina de 1500 y la concentración de los dos nombres más populares entre mujeres es aún mayor que a principios de siglo. Este hecho sugiere que los patrones onomásticos reflejan los distintos papeles que adoptaron hombres y mujeres en el seno de la comunidad morisca de Granada, donde ellos fueron los interlocutores entre las dos comunidades y ellas evitaron el contacto con los cristianos viejos al tiempo que perpetuaban su cultura en el espacio privado del hogar.

Igualmente, a través del análisis onomástico diacrónico se constata una evolución muy limitada del sobrenombre de los moriscos granadinos desde su conversión hasta su expulsión de Granada. Al dividir los sobre-nombres de origen árabe en los distintos componentes del sistema onomástico por el que se rige, encontramos que las frecuencias se mantienen casi constan-tes de 1500 a 1509. Esto indica, por una parte, la más que probable autentici-dad de estos elementos como apelativos de uso corriente entre la otrora sociedad nazarí y, 
por otra, que estos sobrenombres no necesariamente sufrieron la presión de las medidas de aculturación. Pese a ligeros incrementos en el uso de sobrenombres castellanos, una gran parte de la población morisca decidió conservar sus sobrenombres de forma casi exclusiva o, en algunos casos, combinados con un sobrenombre cristiano. Si bien las formas públicas mixtas (castellanas y árabes) de la designación morisca se difundieron a lo largo del siglo, las formas propiamente híbridas en el apelativo - es decir, en las que se ha producido un trasvase del contenido de un sobrenombre árabe al cristiano- son bastante más exiguas, pues no hubo voluntad de traducir al castellano los antiguos sobrenombres árabes, como el laqab o la nisba, que se prestaban a ello.

Este modus operandi antroponímico, sin embargo, no es forzosamente extrapolable a otras comunidades moriscas ni a otro contexto espacio-temporal. A partir de esta metodología es preciso investigar distintos periodos para una misma comunidad, como la granadina que padecerá otro cambio de nombre al verse obligada a emigrar de sus tierras hacia otros puntos de la Península. Posteriormente, estará expuesta a una evolución onomástica en su diáspora interna hasta la expulsión final en el siglo XVII, a continuación de la cual se puede constatar una nueva mutación de sus antropónimos en tierras islámicas. Son fases que coinciden con cambios turbulentos ineludibles que dislocan los cimientos culturales de un colectivo en constante litigio sin tregua.

En su estudio sobre la convivencia entre moriscos granadinos y cristianos viejos, Griffin plasmó el concepto de "un muro invisible" para expresar la incomprensión y la falta de entendimiento que se vivía entre la ortodoxia cristiana y aquellos miembros de la comunidad morisca que, sin embargo, habían aceptado con pleno convencimiento su credo cristiano ${ }^{190}$. Era un muro construido de todo tipo de fragmentos culturales, de comportamientos antropológicos, de costumbres profundamente arraigadas, de formas de expresión intrínsecas a cada comunidad. No obstante, no era forzosamente un muro entre cristianos y musulmanes, es decir, entre dos religiones irreconciliables. Era un muro más difícil de perfilar, entre dos culturas ancestrales en desigualdad de condiciones, y donde una de ellas, de forma algo errática, pretendía erradicar socialmente a la otra. Muchos de estos elementos diferenciadores propios de los moriscos no estaban reñidos con la exigencia de ser buenos cristianos, pero al verse negados por las autoridades pudieron tener en ciertos casos el efecto contrario de buscar una expresa afirmación religiosa o una más explícita alteridad cultural.

La problemática de la onomástica, aunque parezca intrínsecamente vinculada al cripto-islamismo, no lo está. A priori, no es tanto una cuestión religiosa como una seña encubierta o manifiesta de la necesidad de mantener vivos aquellos elementos reconfortantes que daban sentido a unos usos que difícilmente

190. N. GRIFFIN, «Un muro invisible’: Moriscos and Cristianos Viejos in Granada», en F.W. HodCROFT et al. (eds.), Mediaeval and Renaissance Studies on Spain and Portugal in Honour of P.E. Russell, Oxford, The Society for the Study of Mediaeval Languages and Literature, 1981, pp. 133-154. 
se podían extirpar de cuajo y a la fuerza. Estos usos antroponímicos fueron evolucionando muy lentamente a lo largo del siglo XVI, para esquivar las rémoras surgidas de un ambiente progresivamente hostil y plagado de un sinfín de contradicciones donde la convivencia y la segregación a menudo se daban la mano.

Tanto la taqìyya onomástica como los elementos oficiales del apelativo morisco son fruto de esta dialéctica y son más que meras etiquetas para la identificación de un individuo, de una familia, de un clan. Estos son elementos claves de la supervivencia de una cultura en lento proceso de asimilación, tanto forzada como inconsciente; unas señas que les permitían enfrentarse con mejores o peores resultados a todo tipo de muros, desde los más efímeros hasta los más sólidos.

\section{RESUMEN}

Las transformaciones padecidas por los musulmanes de Granada a raíz de la conversión masiva de 1499-1500 se reflejan en el cambio antroponímico inicial y su evolución durante el siglo XVI. En este estudio se evalúa la autenticidad de los nombres árabes en los documentos castellanos y se propone una metodología onomástica que abarca dos sistemas diversos (el árabe y el castellano) y que permite un cierto grado de sincretismo. La onomástica comparativa (sincrónica y diacrónica) desde la Edad Media hasta la Moderna, con muestras de otros colectivos permite calibrar el grado de aculturación de los moriscos y descubrir patrones de comportamiento cultural que resultan difícilmente discernibles por otros medios.

Palabras clave: conversión religiosa, aculturación, onomástica árabe, onomástica castellana, antroponimia, mudéjares, moriscos, Granada, reino nazarí.

\section{ABSTRACT}

The Muslims of Granada experienced a series of transformations due to the widespread conversions of 1499-1500 which is mirrored in the initial anthroponymic change and its subsequent evolution in the sixteenth century. This study assesses the authenticity of Arabic names in Castilian records and proposes an onomastic methodology that bridges two diverse systems (Arabic and Spanish) and manifests a certain degree of synchretism. A comparative onomastic study (both synchronic and diachronic) from medieval to early modern times, using various samples of other social groups allows us to gauge the degree of acculturation of the Moriscos and to discover patterns of cultural behaviour that would otherwise be difficult to discern.

Key words: religious conversion, acculturation, Arabic onomastics, Spa-nish onomastics, anthroponymy, Mudejar, Morisco, Granada, Nasrid kingdom. 